\title{
Genetic, Genomics, and Responses to Stresses in Cyanobacteria: Biotechnological Implications
}

\author{
Corinne Cassier-Chauvat $(\mathbb{D}$, Victoire Blanc-Garin and Franck Chauvat *(D) \\ Institute for Integrative Biology of the Cell (I2BC), Université Paris-Saclay, CEA, CNRS, \\ 91198 Gif-sur-Yvette, France; corinne.cassier-chauvat@cea.fr (C.C.-C.); victoire.blanc-garin@cea.fr (V.B.-G.) \\ * Correspondence: franck.chauvat@cea.fr; Tel.: +33-1-69-08-78-11
}

Citation: Cassier-Chauvat, C.;

Blanc-Garin, V.; Chauvat, F. Genetic, Genomics, and Responses to Stresses in Cyanobacteria: Biotechnological Implications. Genes 2021, 12, 500. https://doi.org/10.3390/ genes 12040500

Academic Editors: Denis Baurain and Luc Cornet

Received: 26 January 2021

Accepted: 25 March 2021

Published: 29 March 2021

Publisher's Note: MDPI stays neutral with regard to jurisdictional claims in published maps and institutional affiliations.

Copyright: (c) 2021 by the authors. Licensee MDPI, Basel, Switzerland. This article is an open access article distributed under the terms and conditions of the Creative Commons Attribution (CC BY) license (https:// creativecommons.org/licenses/by/ $4.0 /)$.

\begin{abstract}
Cyanobacteria are widely-diverse, environmentally crucial photosynthetic prokaryotes of great interests for basic and applied science. Work to date has focused mostly on the three nonnitrogen fixing unicellular species Synechocystis PCC 6803, Synechococcus PCC 7942, and Synechococcus PCC 7002, which have been selected for their genetic and physiological interests summarized in this review. Extensive "omics" data sets have been generated, and genome-scale models (GSM) have been developed for the rational engineering of these cyanobacteria for biotechnological purposes. We presently discuss what should be done to improve our understanding of the genotype-phenotype relationships of these models and generate robust and predictive models of their metabolism. Furthermore, we also emphasize that because Synechocystis PCC 6803, Synechococcus PCC 7942, and Synechococcus PCC 7002 represent only a limited part of the wide biodiversity of cyanobacteria, other species distantly related to these three models, should be studied. Finally, we highlight the need to strengthen the communication between academic researchers, who know well cyanobacteria and can engineer them for biotechnological purposes, but have a limited access to large photobioreactors, and industrial partners who attempt to use natural or engineered cyanobacteria to produce interesting chemicals at reasonable costs, but may lack knowledge on cyanobacterial physiology and metabolism.
\end{abstract}

Keywords: Synechocystis PCC 6803; Synechococcus PCC 7942; Synechococcus PCC 7002; biodiversity; genotype-phenotype relationships; conjugation; transformation; RSF1010 plasmid; neutral cloning sites

\section{Introduction}

Cyanobacteria are ancient Gram-negative prokaryotes that perform oxygenic photosynthesis and are phylogenetically close to recently discovered non-photosynthetic bacteria termed Melainabacteria and Sericytochromatia [1,2]. Cyanobacteria are regarded as the producer of the atmospheric oxygen $\left(\mathrm{O}_{2}\right)$ of Earth [3] and the ancestors of the plant chloroplast [4]. Cyanobacteria capture solar energy at high efficiencies (3-9\%) [5] to power up their efficient photoautotrophic metabolism, which fixes huge amounts of inorganic carbon $\left(\mathrm{CO}_{2}, \mathrm{NaHCO}_{3}\right.$, and $\left.\mathrm{Na}_{2} \mathrm{CO}_{3}\right)$ and nitrogen $\left(\mathrm{N}_{2}, \mathrm{NH}_{4}, \mathrm{NO}_{2}, \mathrm{NO}_{3}\right.$, or urea) [6,7], into an enormous biomass [8] that supports a large part of the food chain.

By colonizing aquatic ecosystems (fresh, brackish, and marine waters) and soils (including deserts) of our planet, cyanobacteria are inevitably exposed to multiple stresses such as solar ultraviolet radiations and variations in light intensity and quality, inorganicnutrients availabilities, temperatures (high and low), salinity, $\mathrm{pH}$ (acidic and basic), drought, and pollutants (herbicides and heavy-metals). In addition, cyanobacteria are involved in numerous interactions with competitors, predators, or symbiotic hosts [9]. Consequently, it is not surprising that cyanobacteria have evolved as a widely diverse organisms, which are of high interest for basic and applied research [10]. They display various metabolisms and morphologies [11,12], and numerous species can differentiate cells, akinetes (spores) and/or heterocysts, which are dedicated to growth or survival under adverse conditions $[13,14]$. 
Thus, cyanobacteria are good model organisms to study the impact of environmental conditions on the physiology, metabolism, and morphology of microbial cells. Furthermore, cyanobacteria synthesize a wide variety of bioactive metabolites (Figure 1), many of which being of interest for human health [15-18], and they are regarded as promising cell factories for the production of chemicals (fuels and biodegradable bioplastics) from highly abundant natural resources: solar energy, water (not necessarily potable), $\mathrm{CO}_{2}$, and minerals, thanks to their active photosynthesis and the synthetic biology tools of model species $[10,19,20]$.
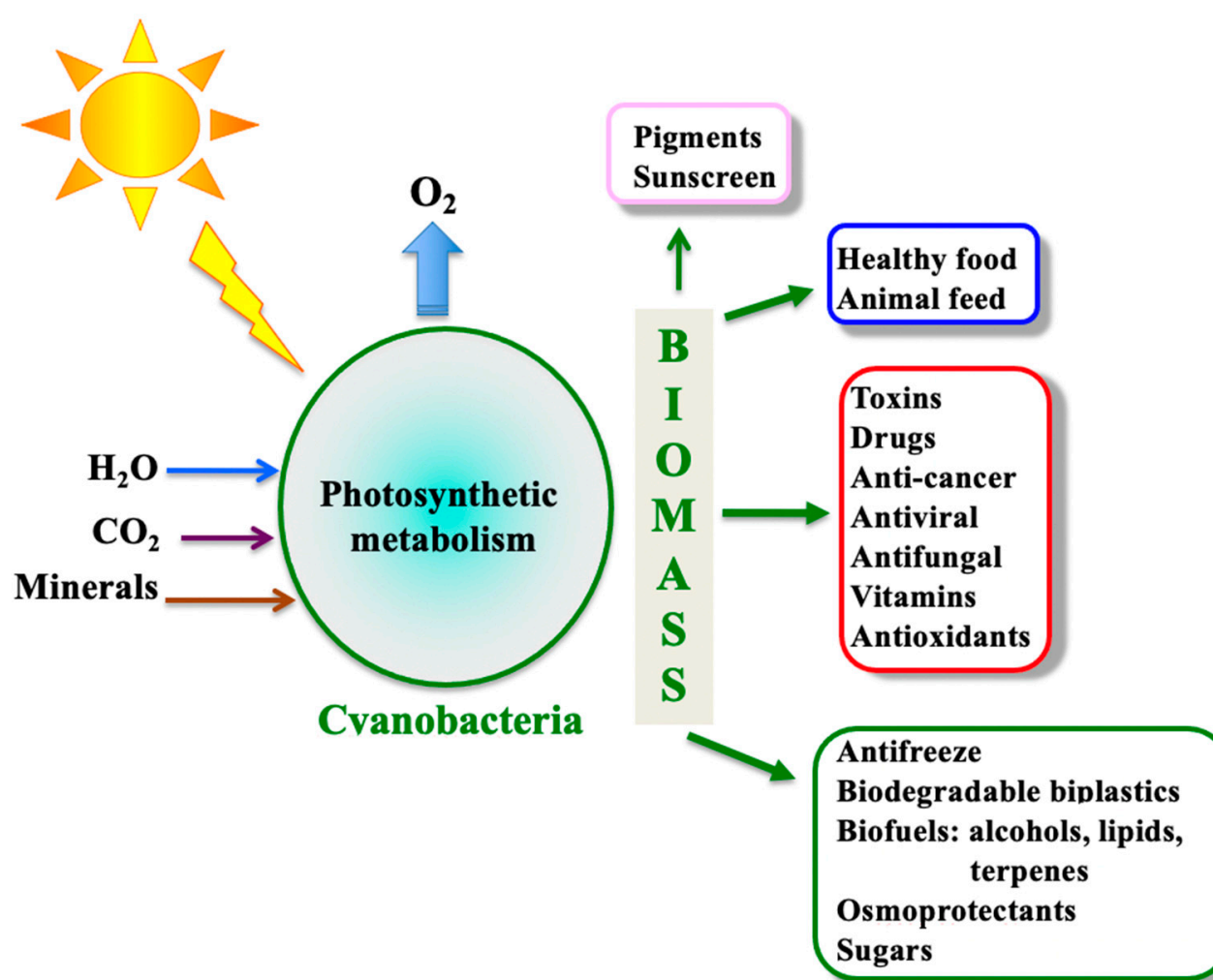

Figure 1. Cyanobacteria can synthesize a wealth of biotechnologically interesting products.

Most of our knowledge on cyanobacteria came from studying the three non-nitrogen fixing, unicellular cyanobacteria Synechocystis PCC 6803, Synechococcus PCC 7942 (formerly named "Anacystis nidulans") and Synechococcus PCC 7002 (formerly named "Agmenellum quadruplicatum PR6") that are (i) straightforward to culture under laboratory conditions, (ii) amenable to genetic manipulation, and (iii) freezable for long-term storage. In this review, we will summarize the genetic and physiological properties of these models, emphasizing on their tolerance to stresses, and the recent progress in their genetics. We will also put forward that in spite of more than three decades of intensive research the genomes of these models still contain a large number of genes and small RNAs (sRNAs) of unknown function. Furthermore, many of the genes annotated "by sequence analogy" with those genes characterized in intensively studied, non-photosynthetic, models such as Escherichia coli might in fact have a different function in cyanobacteria. This situation makes comparative genomics and metabolic modeling difficult. Consequently, we will discuss that to better understand and exploit the wide biodiversity of cyanobacteria, strong efforts should be put in large-scale analysis of genes and sRNAs functions in model cyanobacteria. Finally, we will emphasize that we need to identify and thoroughly study new cyanobacteria endowed with natural properties of interest for basic or applied researches, and test whether the synthetic biology tools developed for model strains can be used to facilitate the engineering of these newly identified cyanobacteria so as to turn their promises into industrial realities. 


\section{Cyanobacteria Being Inevitably Exposed to Photo-Oxidative Stress Have Developed the Evolutionary-Conserved Glutathione System}

Having evolved the oxygenic photosynthesis [21], cyanobacteria were the first organisms to be exposed to the toxic reactive oxygen species (ROS): singlet oxygen $\left({ }^{1} \mathrm{O}_{2}\right.$ ), superoxide anion $\left(\mathrm{O}_{2}{ }^{-}\right)$, hydrogen peroxide $\left(\mathrm{H}_{2} \mathrm{O}_{2}\right)$, and hydroxyl radical $(\mathrm{OH})$ [22] that are generated when the light-driven electron transport exceeds what is needed for nutrients assimilation [23]. Accordingly, cyanobacteria represent a major source of ROS in natural aquatic environments [24].

To cope with ROS, cyanobacteria have developed the glutathione system [3]. It comprises the glutathione tripeptide (gamma-glutamyl-cysteinyl-glycine) and numerous glutathione-dependent enzymes [25], which have been conserved during evolution [26-29]. Glutathione is abundant in all organisms (concentration ranging from 0.1 to about $10 \mathrm{mM}$ ) where it plays pleiotropic roles in cell life and resistance to stresses $[25,30]$. Supporting the notion that cyanobacteria have evolved the glutathione system, the glutathione synthesis enzyme GshB and several glutathione transferases of the model cyanobacterium Synechocystis PCC 6803 were shown to play a prominent role in the tolerance to $\mathrm{O}_{2}$ and photo-oxidative stress [31,32].

Glutathione occurs under two redox forms: the reduced (GSH) and the oxidized, dimeric (GSSG) forms. GSH, the major form, maintains the intracellular compartment in a reduced state. It provides electrons to the GSH-dependent enzymes glutaredoxins and glutathione transferases that operate in defenses against photo-oxidative stress and heavy metal pollutants [32-34]. These toxic-only metals inactivate many enzymes, by reacting with the thiol-group of their cysteines and/or displacing their normal metal cofactors [35]. To protect cells from metals, GSH can chelate them outside the cells under the form of large complexes that cannot penetrate into the cells [36]. GSH can also form a $\mathrm{Fe}(\mathrm{II}) \mathrm{GSH}$ complex, which likely supplies Fe for the synthesis of the Fe cofactor or (Fe-S) clusters of many metalloenzymes operating in photosynthesis, respiration, or other cellular functions $[30,37,38]$.

Oxidative stress can also generate disulfides bridges between two cysteinyl-residues of either the same or two proteins, or a protein and a molecule of glutathione, which otherwise affect protein activity [33,39]. The glutathionylation/deglutathionylation process has been studied in the best studied unicellular cyanobacterium Synechocystis PCC 6803 where about 400 proteins can be glutathionylated in vitro [40]. These proteins participate in a wide range of cellular and metabolic processes including carbon and nitrogen metabolisms, cell division, stress responses and hydrogen production [40]. The glutathionylation/deglutathionylation control of the antioxidant peroxiredoxin II, the mercuric reductase, the AbrB2 transcription factor, and the metabolic enzyme 3-phosphoglycerate dehydrogenase was confirmed by biochemical studies with the purified recombinant proteins $[34,40,41]$. Attesting its importance for living organisms, the redox glutathionylation/deglutathionylation process and the glutathione transferase and glutaredoxin enzymes involved in its control have been conserved during evolution from cyanobacteria to plants and human $[26,29,40,42,43]$.

Upon cell detoxication, GSH is oxidized for the glutathione disulfide form, GSSG, which can be reduced back to GSH by various factors, such as the NADPH-using glutathione reductase enzyme (GR), which occurs in most cyanobacteria [25] and other aerobic organisms [27,44], except the model cyanobacteria Synechocystis PCC 6803 [45] and Synechococcus PCC 7002 [25].

\section{Cyanobacteria Possess Widely Diverse Genomes That Contain a Wealth of Unknown Genes and Poorly Characterized Multigene Families}

The first articles reporting the sequence of an entire bacterial genome (Hemophilus influenzae, 1,830,137 bp; Mycoplasma genitalium, 580,070 bp) appeared in 1995 [46,47]. Shortly thereafter, the sequence of the 3,573,470-bp chromosome of the best studied unicellular cyanobacterium Synechocystis PCC 6803 was reported [48]. Currently, about 2000 complete or draft sequences of cyanobacterial genomes are accessible in public data bases such 
as the DOE joint genome institute (https://genome.jgi.doe.gov/portal/, accessed on 15 March 2021) and the Microbial Genome Database for Comparative Analysis (http: // mbgd.genome.ad.jp/, accessed on 15 March 2021). This number is steadily increasing in the frame of metagenomic analyses [49-52].

The genome of cyanobacteria differs in size, ranging from 1.44 Mbp [53] to 12.07 Mbp [54], and GC content (30-60\%), probably as a result from gene gains and losses [55] transferred by plasmids, insertion sequences [56], and/or cyanophages [57-59]. Cyanophages infecting marine cyanobacteria contain genes important for photosynthesis, which could facilitate their transfer among marine cyanobacteria [60]. Instances of horizontal gene transfer are inferred on the basis of observations of patchy phylogenetic distribution and/or atypical nucleotide composition of several genes [55,59].

All cyanobacteria possess a circular chromosome and, depending on the species, a linear chromosome (rarely) and/or one to several circular plasmids (frequently), excepted the marine species UCYN-A, Prochlorococcus and Synechococcus, which have a small chromosome (1.44-2.7 Mbp), but no plasmids [53,61]. Some cyanobacterial plasmids contain genes likely involved in important processes, such as cysteine biosynthesis [62], thermal tolerance [63], resistance to metal stress [64], or DNA repair [58]. The marine cyanobacterium Acaryochloris marina MBIC1101, which has a $6.5 \mathrm{Mbp}$ circular chromosome, has $25 \%$ of its genes located on its nine large ( $\geq 100 \mathrm{kbp}$ ) single-copy plasmids [65].

An unusual genome organization was observed in two strains of the unicellular genus Cyanothece. The genome of Cyanothece ATCC51142 (5.46 Mbp) harbors two chromosomes (one circular of $4.39 \mathrm{Mbp}$; and one linear of $0.4 \mathrm{Mbp}$ ) and four plasmids (10-39 kbp) [66,67]. Cyanothece PCC 7822 has a genome of $7.84 \mathrm{Mbp}$ that comprises one circular chromosome (6.09 Mbp), three linear chromosomal elements (880, 474, and $14 \mathrm{kbp})$ and three plasmids [67]. These findings are interesting because a few bacteria possess a linear chromosome, such as the (non-photosynthetic) soil bacteria of the genus Streptomyces, which synthesize a wide variety of bioactive secondary metabolites [68], like cyanobacteria $[16,17,69]$. In Streptomyces, the linear chromosome exhibits a remarkable genetic organization with grossly a central conserved region flanked by variable chromosomal arms [70]. Based on these observations, it would be interesting in the future to compare the plasticity of linear versus circular chromosomes of cyanobacteria.

\section{Interest and Current Limitations of Comparative Genomics}

The comparative analysis of cyanobacterial genomes allows to determine which genes are present in any particular genome and which ones are absent. These findings serve to determine the pan-genome, which describes the entire genes set of all cyanobacteria analyzed. It includes (i) a core-genome, which comprises the sets of genes that exist in each of the strains analyzed [71] and (ii) the dispensable-genome, which comprises the genes present in a subset of the studied strains and species-specific genes [72]. For such analyses, strains can be selected on the basis of their natural habitats [73], their physiology and/or morphology [74], and/or their phylogenetic position determined by 16S-rRNA sequence comparison [75]. Such comparative genome analyses revealed habitatspecific (or heterocyst-specific) cyanobacterial proteins [72]. It was also revealed that cyanobacteria occupy a unique position among prokaryotes as a hub between anaerobes and obligate aerobes [76] and that the earliest cyanobacteria were small and unicellular, while filamentous forms appeared shortly afterwards [77]. Comparative genome studies were also used to discuss plastid evolution [78]. When applied to two closely related cyanobacteria, comparative genomics can be used to predict the behavior of one strain relative to the other one. As a rare example of such comparison, Synechocystis PCC 6803 was found to be more resistant to zinc excess than Synechocystis PCC 6714 as it was predicted [79]. Comparative genomic information is also crucial for genome-based reconstruction of an organism's metabolism as done for Synechocystis PCC 6803 to predict which metabolic reaction or pathway should be engineered to increase the production of biotechnologically interesting chemicals [80-85]. 


\subsection{Danger of Genome Annotation Based Only on Sequence Comparison}

Generating robust and accurate genome-scale models (GSMs) is an iterative process dependent on the expansion and updating of draft simulation models with available experimental data obtained after measurement of fluxes and metabolic pool sizes [80,86,87]. However, GSMs are largely based on gene function predicted "by sequence analogy" with genes characterized in other model organisms, which may behave differently in the studied organism [88]. In Synechocystis PCC 6803, the best studied model, only ca. 1050 coding sequences $(\sim 30 \%)$ have assigned functions [80,89], which may turn out to differ from those determined in well-studied heterotrophic models. For examples, the Synechocystis PCC 6803 LexA protein regulates the expression of genes involved in carbon assimilation [90], not DNA repair as it occurs in E. coli. Furthermore, the NAD $(\mathrm{P}) \mathrm{H}$ dehydrogenase transcription factor (NdhR, Sl11594), homologous to the proteobacterial regulators of the Calvin-Benson-Bassham metabolic pathway (CbbR, hereafter referred to as Calvin cycle), does not regulate the transcription of Calvin cycle genes [91]. Instead, $\mathrm{NdhR}$ regulates numerous genes involved in the transport and assimilation of inorganic carbon $\left(\mathrm{CO}_{2}\right.$ and bicarbonate) $[6,92,93]$.

In addition, a single cyanobacterial protein can have more than one function. The fructose-1,6/sedoheptulose-1,7-bisphosphatase (FBP/SBPase) operates in both the Calvin cycle and gluconeogenesis [94]. The CrtLdiox protein is also dual-function enzyme with both lycopene cyclase and dioxygenase activity [95]. The IsiA protein is active in both the light-harvesting ability of PSI and the photoprotection of PSII [96]. The AgrE enzyme catalyzes two sequential reactions in arginine catabolism, in converting arginine to ornithine, and then ornithine into proline $[97,98]$. The ApalaDH enzyme transforms pyruvate to L-alanine, L-alanine back to pyruvate, and glyoxylate to glycine [99]. The sucrose-synthesis SPS enzyme has sucrose-phosphate synthase and sucrose-phosphate phosphatase activities [100]. The KatG enzymes have both catalase and peroxidase activities, which are also capable of oxidizing chloride, bromide, and iodide compounds [101,102].

4.2. Identification of Essential Genes at the Level of a Whole Genome for a Better Understanding of the Genotype-Phenotype Relationships

To use genomic data for reconstruction of an organism's metabolism it is also important to identify the comprehensive set of genes that are essential to cell growth in well-defined conditions. This has been addressed using transposon mutagenesis in Synechocystis PCC 6803 [103,104] and Synechococcus PCC 7942 [105-108]. For the same purpose, the construction of a whole genome library of gene insertion plasmids has been undertaken in Synechocystis PCC 6803 [7]. These works will certainly contribute to decrease the high number of proteins with still unknown function. In Synechocystis PCC 6803, transposon mutagenesis has been useful to study (i) photosynthesis [109-111], (ii) the transport of $\mathrm{CO}_{2}$ or bicarbonate [112,113], (iii) the production of the poly-3-hydroxybutyrate (PHB) biodegradable bioplastic [114], and (iv) the NADPH:plastoquinone oxidoreductase complex operating in plastoquinone reduction and cyclic electron transfer (CET) around photosystem I [115-121]. Transposon mutagenesis has been also useful in Synechococcus PCC 7942 to identify a gene in fatty acid production [122].

\subsection{Importance of Deciphering the Selectivity/Redundancy of Multiple Gene Families}

To generate robust and predictive model of the metabolism of cyanobacteria, it is also important to unravel the redundancy/selectivity of multigene families, such as those that code for the stress-responsive redox proteins ferredoxins, glutaredoxins, and glutathione transferase.

Ferredoxins (Fed), are small (acidic) proteins present in most organisms. They use their iron-sulfur cluster $(\mathrm{Fe}-\mathrm{S})$ to distribute electrons to various metabolic pathways involved in nutrients assimilation [123]. The best studied cyanobacterium Synechocystis PCC 6803 possess nine Feds. The Fed1-6 proteins possess a (2Fe-2S) center, while Fed7 harbors a (4Fe-4S) cluster. In contrast both Fed8 and Fed9 have two clusters: (3Fe-4S) (4Fe-4S) 
and (4Fe-4S) (4Fe-4S), respectively. The highly abundant Fed1 protein, essential to photosynthesis [124,125], is encoded by a light-inducible gene [126]. The low-abundant Fed2Fed9 proteins are encoded by stress-responsive genes (light, carbon, herbicides, or heavy metals), which have differential importance (crucial/dispensable) for the photoautotrophic growth and/or the resistance to stresses $[45,123,125,127]$. Fed1, Fed7, and Fed9 participate in a ferredoxin-glutaredoxin-thioredoxin crosstalk pathway that operates in the protection against oxidative and metal stresses [45]. Fed7, but not Fed9, interacts with a DnaJ-like protein, an interaction that has been strengthened in photosynthetic eukaryotes in the form of a Fed7-DnaJ fusion protein [123]. Fed7 also has a regulatory role under photooxidative stress [128]. Conversely, Fed9, but not Fed7, interacts with the Flv3 flavodiiron protein involved in the photoreduction of $\mathrm{O}_{2}$ to $\mathrm{H}_{2} \mathrm{O}$ [123]. Other ferredoxins partners $[129,130]$ should be studied to better understand the selectivity/redundancy of ferredoxins in Synechocystis PCC 6803. Attesting their importance for the life of cyanobacteria, the fed genes were highly conserved in cyanobacteria. For example, the other models Synechococcus PCC 7002 and Synechococcus PCC 7942 have, respectively, nine and six fed genes, while the symbiotic strain Acaryochloris marina MBIC11017 endowed with a large genome (8.36 Mb) possesses sixteen $\mathrm{fed}$ genes [123].

Like ferredoxins, the evolutionary-conserved enzymes glutaredoxins (Grxs) are widely distributed in cyanobacteria $[25,131]$. Grxs use electrons provided by glutathione (GSH), or the thioredoxin reductase enzyme [45,132], to reduce the oxidative-stress-generated disulfides occurring between two cysteinyl-residues of either the same or two proteins, or a protein and a molecule of glutathione, which otherwise affect protein activity $[33,39]$. The dithiol Grxs, which possess a CXXC redox center ( $C$ and X stand for cysteine and any other amino acid, respectively), catalyze the reduction in protein disulfides or glutathioneprotein mixed disulfides (the latter activity is named "deglutathionylation"). The monothiol Grxs, which have a CXXS redox center ( $\mathrm{S}$ stands for serine), operates in iron sensing and trafficking the biogenesis of iron-sulfur clusters of proteins and deglutathionylation [30]. All cyanobacteria possess a monothiol Grx-encoding gene and a variable number of dithiol Grx genes [25]. Synechocystis PCC 6803 possesses three Grxs, which are all dispensable to the standard photoautotrophic growth $[25,133]$. The dithiol enzymes Grx1 and Grx2, which can interact together [45], operate in tolerance to $\mathrm{H}_{2} \mathrm{O}_{2}$ [45,133], arsenate [134,135], selenate [45], mercury, and uranium [34]. Grx1 can reactivate the oxidized (glutathionylated) form of the mercuric reductase enzyme by catalyzing its deglutathionylation [34]. The monothiol Grx3 (CGFS redox center) enzyme forms a homodimer bridged by a glutathione-ligated (2Fe-2S) cluster [26]. This feature, which has been conserved in Grx3 orthologs from cyanobacteria to plants and mammals, likely operates in Fe sensing and distribution of (2Fe-2S) cluster [26,30,136].

Another important multiple genes family encodes the evolutionary-conserved glutathione transferase (GT) enzymes, which can conjugate glutathione (GSH) on diverse toxics (oxidants, chemicals, and heavy metals) thereby generating water-soluble complexes that can then be degraded or excreted out of the cell $[33,137,138]$. GST also operate in the glutathionylation/deglutathionylation process [42,43]. Glutathione-S-transferases (GST) are commonly divided in three different families: (i) cytosolic GSTs (the largest family), (ii) mitochondrial GSTs, and (iii) microsomal (membranous) GSTs designated as MAPEGs (membrane-associated protein involved in ecosanoïd and glutathione metabolism) [139]. Little is known about GSTs in cyanobacteria though they are regarded as having evolved the oxygen-generating photosynthesis, as well as GSH and GSH-dependent enzymes to protect themselves against the toxic ROS (reactive oxygen species) massively produced by their active photosynthesis [3]. Based on phylogenetic tree analyses, 12 GST classes were identified in cyanobacteria [140,141]. Cyanobacterial GSTs have been studied mostly in Synechocystis PCC 6803, which possesses six GST, namely, Sll0067, Sll1147, Sll1545, Sll1902, Slr0236, and Slr0605 [142-144]. While the role of Sl11902 and Slr0605 is still unknown, Sll1545 and Slr0236 were shown to operate in the protection against photo-oxidative stress triggered by high light or $\mathrm{H}_{2} \mathrm{O}_{2}$ [32]. Sll1147 plays a prominent role in tolerance to mem- 
brane stresses triggered by heat, cold, and lipid peroxidation [29]. S1l0067 operates in the protection against methylglyoxal (MG), a toxic metabolite by-product of the catabolism of sugars, lipids, and amino-acids, which causes diabetes in human. S110067 catalyzes the conjugation of GSH with MG, the first step in MG detoxification catalyzed by the glyoxalase enzymes [145].

\section{A Few Cyanobacteria Are Currently Amenable to Gene Manipulation, Leaving the Wide Biodiversity of Cyanobacteria Largely Unexplored}

Historically, three non-nitrogen fixing unicellular cyanobacteria Synechocystis PCC 6803 (euryhaline strain), Synechococcus PCC 7942 (freshwater strain formerly named "Anacystis nidulans") and Synechococcus PCC 7002 (marine strain formerly named "Agmenellum quadruplicatum PR6") were chosen as model because they possess a simple morphology [146,147], a small genome (see above) and the important natural capability to be genetically transformed (see below). In addition, the freshwater strain Anabaena (Nostoc) PCC 7120 was also chosen as a genetically manipulable representative of filamentous (pluricellular) cyanobacteria [148]. This latter model is well used to analyze the differentiation of heterocysts, the cells dedicated to the fixation of atmospheric nitrogen, and their communication with vegetative cells [14], which are not the focus of the present review.

Although these four species are phylogenetically distant, they represent only a limited part of the wide biodiversity of cyanobacteria. This is evident from the comparison of the size and organization of their genomes (2.7-7.2 Mbp, absence of linear chromosome) with those of many other cyanobacteria (1.44-12M bp see above, presence of a linear chromosome in a few species).

New rapidly growing unicellular cyanobacteria have been recently described, namely, the freshwater strains Synechococcus UTEX 2973 [149], Synechococcus PCC 11801 [150], and Synechococcus PCC 11802 [151] and the marine strain Synechococcus PCC 11901 [80,152]. Synechococcus PCC 11901 tolerates high temperatures, up to $43{ }^{\circ} \mathrm{C}$, which are non-optimal for Synechococcus UTEX 2973 [150,153], Synechococcus PCC 11801 [150,151], and Synechococcus PCC 7942 [154], and even detrimental to Synechocystis PCC 6803 [29,155]. Synechococcus PCC 11801 [150], Synechococcus PCC 11802 [151], and Synechococcus PCC 11901 [152] are naturally transformable, unlike Synechococcus UTEX2973 [150]. The latter strain was made transformable by cloning the Synechococcus PCC 7942 pilN gene encoding the Tfp pilus assembly protein [156].

Unfortunately, Synechococcus UTEX2973, Synechococcus PCC 11801, and Synechococcus PCC 11802 are very closely related to the freshwater model Synechococcus PCC 7942, in sharing, respectively, $99.8 \%$ and about $83 \%$ of genome identity with it $[149-151,157]$. Similarly, Synechococcus PCC 11901 shares 96.7\% sequence identity with the marine model Synechococcus PCC 7002 [87,152]. Thus, future studies carried out with these new model strains will not significantly increase our understanding of the cyanobacterial biodiversity.

6. Properties of the Intensively Studied Unicellular Cyanobacteria Synechocystis PCC 6803, Synechococcus PCC 7942, and Synechococcus PCC 7002

The three non-nitrogen fixing models Synechocystis PCC 6803, Synechococcus PCC 7942, and Synechococcus PCC 7002 have specific physiological properties that can influence their potential to serve as cell factories for biotechnological projects. Synechocystis PCC 6803 in being one of the few cyanobacteria capable to grow under photoautotrophic, mixotrophic, or heterotrophic conditions [147] has become the best studied cyanobacterium. It serves as model to study the photoautotrophic metabolism $[6,7,93]$, the crucial importance of the carbon/nitrogen metabolic balance [6,93], and the responses to stresses [35]. Such investigations are also carried out, to a lesser extent, with Synechococcus PCC 7002 and Synechococcus PCC 7942. The latter model is well used to investigate cell division [158], the carbon/nitrogen metabolic crosstalk [93], the circadian rhythm [159], and the biogenesis of the $\mathrm{CO}_{2}$-concentrating carboxysome organelle [160]. 
6.1. Genome Organization in the Intensively Studied Unicellular Cyanobacteria Synechocystis PCC 6803, Synechococcus PCC 7942, and Synechococcus PCC 7002

Synechocystis PCC 6803, the best studied model, harbors a $3.57 \mathrm{Mbp}$ circular chromosome [48], which has a copy number of about 10-22 per cell [161,162], and seven plasmids of sizes 2.3 [163,164], 2.4 [165], 5.2 [166], 44, 103, 106, and $120 \mathrm{kbp}$ [167]. The ploidy of the three smaller plasmids $2.3-5.2 \mathrm{kbp}$ was shown to be similar and increased from 3 to 8 copies per chromosome in cells reaching the stationary phase of growth. In contrast, the ploidy of the four larger plasmids, ranging from $\sim 0.3$ to 1.2 per chromosome depending on the studied plasmid, varied little with the growth phase [168]. The $5.2 \mathrm{kbp}$ plasmid appeared to be dispensable to the standard photoautotrophic growth of Synechocystis PCC 6803 [169]. In contrast, large plasmids appeared to be essential (cells could not lose these plasmids), likely because they encode several toxin-antitoxin systems mediating plasmid maintenance $[170,171]$ and they operate in beneficial functions such as potassium transport [172], copper resistance [173], and the metabolic tricarboxylic acid cycle [174].

The other model cyanobacteria Synechococcus PCC 7942 and Synechococcus PCC 7002 possess a circular chromosome of, respectively, 2.69 Mbp and 3.0 Mbp, each occurring at two to five copies per cell [175-177]. In addition, Synechococcus PCC 7942 has two plasmids of 7.84 [178] and $46.4 \mathrm{kbp}$ [179], while Synechococcus PCC 7002 contains six plasmids [180] from 4.8 [181] to $186 \mathrm{kbp}$. The $7.84 \mathrm{kbp}$ plasmid of Synechococcus PCC 7942 is not essential to its photoautotrophic growth $[182,183]$. In comparison, the well-studied filamentous cyanobacterium Anabaena (Nostoc) PCC 7120 has a 7.2 Mbp genome that comprises a circular chromosome of $6.41 \mathrm{Mbp}$ and six plasmids of sizes 408.10, 186.614, 101.96, 55.41, 40.34, and $5.58 \mathrm{kbp}$ [184].

6.2. Physiological Properties of Synechocystis PCC 6803, Synechococcus PCC 7942, and Synechococcus PCC 7002 and Biotechnological Implication

In agreement with them having different genome size and organization, the three model cyanobacteria also show different physiologies. Synechococcus PCC 7002, which has a doubling time of $\sim 2.6 \mathrm{~h}$ [185], grows 2-7 times faster than Synechococcus PCC 7942 and Synechocystis PCC 6803 depending on the environmental conditions $[149,183,186]$. However, Synechococcus PCC 7002 requires vitamin B12 (cobalamin) to grow [146], unlike Synechocystis PCC 6803 and Synechococcus PCC 7942 [147]. Thus, the cost of vitamin B12 supplementation should be considered when Synechococcus PCC 7002 is to be used for biotechnological purposes requiring large-scale cultures. The vitamin B12 auxotrophy of Synechococcus PCC 7002 is due to the fact that it uses a cobalamin-dependent methionine synthase (MetH) for the synthesis of methionine, though it cannot synthesize cobalamin de novo. Recently, a cobalamin-independent methionine synthase metE gene from Synechococcus PCC 73109 was expressed in Synechococcus PCC 7002 to relieve its cobalamin auxotrophy [187], but this modified Synechococcus PCC 7002 sub-strain has been little employed yet.

All three model cyanobacteria are growing well on ammonium and nitrate, the usual nitrogen sources for cyanobacteria. In addition, both Synechocystis PCC 6803 and Synechococcus PCC 7002 can grow on urea (a frequent pollutant) as the sole nitrogen source [188-190], unlike Synechococcus PCC 7942 [190]. Furthermore, Synechococcus PCC 7002 and Synechocystis PCC 6803 are salt resistant (Synechococcus PCC 7002 is a marine strain), unlike the freshwater strain Synechococcus PCC 7942 [191]. Thus, Synechococcus PCC 7942 is not a suitable cell factory for future projects aiming at the photosynthetic production of chemicals in waters polluted by urea and/or salt to save the costs of potable waters.

As iron is an essential enzyme cofactor for oxygenic photosynthesis, cyanobacteria utilize multiple strategies to maintain iron levels within a desired range. One of them is the synthesis, export, and re-import of ferric ion chelators called siderophores. Both Synechococcus PCC 7942 and Synechococcus PCC 7002 can synthesize siderophore, unlike Synechocystis PCC 6803 that can only import the siderophore produced by other organisms [192]. These three model cyanobacteria have other metabolic differences. The RbcX chaperone operating in assembly of the $\mathrm{CO}_{2}$-fixing RubisCO enzyme is essential in Synechococcus PCC 7002 [193], whereas it is dispensable in Synechococcus PCC 7942 [194] and Synechocystis PCC 6803 [195]. In addition, Synechocystis PCC 6803 has four flavodiiron proteins (Flv1-Flv4) [196], which 
function as heterodimers Flv1/3 and Flv2/4. Flv1/3 catalyzes the NAD(P)H-driven reduction in oxygen to water on the acceptor side of PSI [196-198], while Flv2/4 operates both in the photoprotection of the photosystem II [199] and in an oxygen-dependent alternative electron flow [200]. Unlike Synechocystis PCC 6803, both Synechococcus PCC 7942 and Synechococcus PCC 7002 possess only Flv1/3, not Flv2/4 [201].

Finally, both Synechocystis PCC 6803 and Synechococcus PCC 7002 secrete extracellular polymeric substances mainly composed of exopolysaccharides, which act in the formation of biofilm and the protection against salt and metals stresses [202-205], unlike Synechococcus PCC 7942 that do not normally form biofilms [206].

6.3. Comparison of the Stress-Responsive Glutathione and DNA Repair Systems of the Model Cyanobacteria Synechocystis PCC 6803, Synechococcus PCC 7942, and Synechococcus PCC 7002

Attesting the importance of the glutathione system for the tolerance to photo-oxidative stress and cell detoxication, most cyanobacteria possess the glutathione system. Its composition varies depending on the species and the environmental challenges they face. Most cyanobacteria have a glutathione reductase (GR) enzyme as Synechococcus PCC 7942, unlike both Synechocystis PCC 6803 and Synechococcus PCC 7002 [25,45]. Furthermore, Synechocystis PCC 6803 and Synechococcus PCC 7002 possess three glutaredoxins (Grxs) operating in tolerance to oxidative and metal stresses [34,45,133-135], whereas Synechococcus PCC 7942 has only two Grxs [25,131]. Another common feature shared by Synechocystis PCC 6803 and Synechococcus PCC 7002 is the fact that they both have an orange carotenoid protein (OCP) operating in photoprotection, whereas Synechococcus PCC 7942 has no OCP [207]. Synechocystis PCC 6803 and Synechococcus PCC 7942 have a MAPEG-type glutathione transferase enzyme operating in the tolerance to temperature stresses [29], which could occur during culture in open ponds, unlike Synechococcus PCC 7002.

Concerning the also important DNA repair system, which has been poorly studied in cyanobacteria, it is worth noting that the three model species have the following common and specific features. Synechocystis PCC 6803 possesses the recD gene, which is absent in Synechococcus PCC 7002 and Synechococcus PCC 7942 [58]. Furthermore, Synechocystis PCC 6803 has recB and recJ, which are duplicated in Synechococcus PCC 7002 and Synechococcus PCC 7942.

Synechocystis PCC 6803 and Synechococcus PCC 7942 have the umuC and umuD genes (umuC is duplicated in Synechocystis PCC 6803), unlike Synechococcus PCC 7002 that has no $u m u C$ and umuD genes [58]. Furthermore, Synechocystis PCC 6803 and Synechococcus PCC 7942 recQ, which is duplicated in Synechococcus PCC 7002.

Synechococcus PCC 7942 has mutT and mutY, whereas Synechococcus PCC 7002 lacks mutT and Synechocystis PCC 6803 lacks mut $Y$ [58].

Synechocystis PCC 6803 and Synechococcus PCC 7002, which can both use exogenous carbohydrates to accelerate their growth [6], possess lex $A$, which encodes a transcription regulator involved in carbon assimilation, not DNA repair [90]. In contrast, the obligate photoautotroph Synechococcus PCC 7942 has no lexA [58].

Synechocystis PCC 6803, Synechococcus PCC 7002, and Synechococcus PCC 7942 have also different features in the simplest DNA repair system, which removes only the basemodifying agent in one single step catalyzed by the AlkB demethylase, the Ogt alkyltranferase, and the Phr photolyase. All three model cyanobacteria possess phr, whereas Synechocystis PCC6803 has alkB but not ogt, Synechococcus PCC7942 has ogt (duplicated) but not alkB, and Synechococcus PCC7002 has neither alkB nor ogt [58].

\subsection{Comparative Analysis of the Growth and Response to Stresses of the Three Model} Cyanobacteria Synechocystis PCC 6803, Synechococcus PCC 7002, and Synechococcus PCC 7942

To better characterize the common and different physiological features exhibited by these three model cyanobacteria, it would be very interesting to perform simultaneous analyses and comparisons of their growth and tolerance to stresses in the same laboratories. This task is of high interest for not only basic science but also for biotechnological projects, which use of robust cell factories capable to withstand the environmental challenges 
imposed by the industrial process and the possible toxicity of the intended products. So far, a very limited number of comparative studies have been carried out. Synechocystis PCC 6803 was shown to be more tolerant than Synechococcus PCC 7942 to UV (and gamma radiations) [90] and to the undecane hydrocarbon [208]. Reciprocally, Synechococcus PCC 7942 appeared to be more tolerant to chromate than Synechocystis PCC 6803, possibly because the sulfate transporters of Synechococcus PCC 7942 have lower affinity to chromate than those of Synechocystis PCC 6803 [209]. Furthermore, chromate generated more ROS (reactive oxygen species) in Synechocystis PCC 6803, as compared to Synechococcus PCC 7942, likely because Synechocystis PCC 6803 has intrinsic levels of superoxide dismutase, catalase and 2-Cys-peroxiredoxin than Synechococcus PCC 7942 [210]. Additionally, interestingly, Synechocystis PCC 6803 and Synechococcus PCC 7002 were reported to be more tolerant to ethanol than Synechococcus PCC 7942 [208,211].

Another important aspect to study is the genetic stability of the recombinant cyanobacteria generated for applied research. It has been reported that many engineered cyanobacteria appeared to be genetically unstable [58]. In one Synechocystis PCC 6803 recombinant strain, the instability was caused by the transposition of an IS5 insertion sequence leading to the inactivation of a regulatory gene [56]. Thus, it is of interest to note that the genomes of Synechococcus PCC 7942 and Synechococcus PCC 7002 are predicted to contain one and approximatively 10 transposase encoding genes, whereas Synechocystis PCC 6803 possesses a single transposase gene.

\subsection{As Observed in Synechocystis PCC 6803, the Sub-Strains of a Single Cyanobacterium Cultivated in Various Laboratories Can Have Different Behaviors}

Another level of complexity is the un-surprising finding that a single cyanobacterium cultivated for some times in different laboratories tend to develop genetic and physiological differences from one laboratory to another. In the case of Synechocystis PCC 6803, originally isolated from a fresh water lake in California [146] and deposited in both the American Type Culture Collection (strain number ATCC 27184) and the Pasteur Culture Collection (strain number PCC 6803), it was reported that several sub-strains cultivated in different laboratories varied in genotypes and/or phenotypes. As compared to the original genome sequence [48], several specific mutations were identified in genes related to photosynthesis, transport, or motility [212-218]. Furthermore, variability in genome copy number was also observed [162]. Moreover, phenotypic variations were also reported including photosynthesis [217], cell size [219], motility [212,218], capability to grow on glucose as the carbon source $[212,220]$, or resistance to temperature and salt $(\mathrm{NaCl})$ stresses [221].

\section{Genetic Characteristics of the Model Cyanobacteria Synechocystis PCC 6803, Synechococcus PCC 7942, and Synechococcus PCC 7002}

Shortly after their selection based on their robustness and simple (unicellular) morphologies [146,147] Synechocystis PCC 6803, Synechococcus PCC 7942, and Synechococcus PCC 7002 were found to be naturally competent for genetic transformation (see below).

7.1. Synechocystis PCC 6803, Synechococcus PCC 7942, and Synechococcus PCC 7002 Are Naturally Competent for Genetic Transformation

Natural competence for transformation of prokaryotes refers to their capability to take up DNA from their environment and incorporate it into their own genome. Originally, antibiotic resistant mutants, generated after UV or chemical mutagenesis, were selected, and their genomic DNA was isolated and used to transform wild type cells selecting for antibiotic resistance. Three naturally transformable species have emerged from such studies, namely, Synechococcus PCC 7942 [222], Synechococcus PCC 7002 (Agmenellum quadruplicatum PR6) [223,224], and Synechocystis sp. PCC 6803 [225]. In Synechococcus PCC 7942, the efficiency of transformation was found to decrease at $\mathrm{pH}$ lower than 7.0 or temperature $\geq 40{ }^{\circ} \mathrm{C}$, two conditions being also unfavorable for growth. Furthermore, transformation was best effective with cells reaching the transition from the first to the second exponential phases of growth, supporting the notion that transformation depends upon the physio- 
logical stage of the culture $[183,226]$. In addition, transformation appeared to be more efficient when expression of the transferred genes was allowed for $24 \mathrm{~h}$ on non-selective solid medium, prior to introducing the selective antibiotic underneath the agar of the plate for its slow diffusion toward the cells for gentle selection of the transformants [183]. Additionally, interestingly, the transformation to Synechocystis PCC6803 was reported to be strongly stimulated after the deletion of the exonuclease recJ gene [227]. Recently, the natural competence for transformation was shown to involve pilus appendages [228] and to be regulated by the circadian clock [229].

In Synechococcus PCC 7002, it was shown that single-stranded DNA cannot transform competent cells. Furthermore, cells in the stationary phase of growth or deprived of nitrogen or light before exposure to donor DNA tend to lose their competence for transformation. In contrast, significant improvement in transformation frequency were achieved by increasing the nitrate content of the culture medium or lowering the temperature from $39^{\circ} \mathrm{C}$ (the optimal temperature for growth) to $30^{\circ} \mathrm{C}$ before exposure to donor DNA [230].

Later, it was established in Synechococcus PCC 7942 [231], Synechococcus PCC 7002 [232], and Synechocystis PCC $6803[161,163,233]$ that the donor DNA is integrated in the chromosome, or an endogenous plasmid (see below) of the recipient cells, through homologous recombination (double crossing-over or gene conversion) occurring on each side of the transferred DNA sequence in the region of homology between both the donor DNA and the recipient DNA. This process, similar to what had been described earlier in Bacillus subtilis [234], was extensively used for deleting cyanobacterial genes (or a part of them) through their targeted replacement by an easy selectable antibiotic resistance marker. Soon after its discovery, natural transformation of cyanobacteria was used in pioneering in vivo analyses of proteins involved in photosynthesis and/or stress resistance, which were performed with Synechocystis PCC 6803 [235-240], Synechococcus PCC 7942 [241-245], and Synechococcus PCC $7002[246,247]$.

The molecular mechanism of natural transformation has been recently described in Synechocystis PCC 6803 [248]. First, DNA uptake from the environment is mediated by binding to the (type IV) pili appendages, which are also involved in cell adhesion and biofilm formation as well as twitching motility. During pilus retraction, the DNA is pulled into the periplasmic space, where one DNA strand is degraded while the other is translocated further across the cytoplasmic membrane by the Com (competence) proteins. The singlestranded DNA arrived in the cytoplasm is protected from nucleases and incorporated into the genome of recipient cells via homologous recombination.

\subsection{Interest and Limitation of the Polyploidy of Synechocystis PCC 6803, Synechococcus PCC} 7942, and Synechococcus PCC 7002

In cyanobacteria, genomic modification is a time-consuming process because these organisms are polyploid. For example, Synechococcus PCC 7942, Synechococcus PCC 7002 and Synechocystis PCC 6803 harbor about 2-5 and 10-12 chromosome copies per cell [161,175-177]. Thus, to create a homoploid mutant, a segregation procedure must be applied to ensure that all chromosome copies in the transformants carry only the modified DNA. This requires multiple rounds of culture streaking in the presence of the selective antibiotic, which can last several weeks. However, the polyploidy of cyanobacteria is not a merely negative trait. It allows to study genes that are essential to cell life. In such cases, we obtain the corresponding heteroploid mutants, which possess both mutant and WT chromosomes copies (with and without the studied vital gene). Such mutants survive because they retain a limited but sufficient amount of the studied essential protein, and they usually have a phenotype different from the wild-type strain. This difference often serves as a guide to infer a role of the studied crucial protein.

\subsection{Utilization of Neutral Genome Sites for Gene Manipulation in Synechocystis PCC 6803, Synechococcus PCC 7942, and Synechococcus PCC 7002}

Transformation has been used extensively for the introduction of endogenous or heterologous genes into neutral chromosomal or plasmid sites, i.e., loci that can be disrupted 
with no negative effect on cellular viability. Many neutral sites localized inside a dispensable gene or intergenic region have been identified in the chromosome or in an endogenous plasmid of Synechocystis PCC 6803 [163,249-252], Synechococcus PCC 7942 [253-255] and Synechococcus PCC 7002 [256-258]. These neutral cloning sites were frequently used for cloning and expression of endogenous, or heterologous, genes involved in cell metabolism, stress responses, or the engineering of recombinant strains for the photosynthetic production of chemicals (see Tables 1-3).

In Synechocystis PCC 6803, the frequently used neutral loci are (i) the gene slr0168 or the intergenic region between slr2030 and slr2031, which have no known function; (ii) the $c p c B$ gene involved in the synthesis of the photosynthetic pigment phycocyanin; and (iii) the three $p s b A$ genes (Table 1). Although $p s b A 1$ is not expressed [235,259], $p s b A 2$ and $p s b A 3$, encoding the D1 protein subunit of the photosystem II, are expressed and dispensable, but they cannot be inactivated simultaneously [259]. The deletion of $p s b A 2$ gene is compensated by an up-regulation of $p s b A 3$ [260]. Neutral sites on the endogenous plasmids pCC5.2 and pCA2.4 have also been identified and evaluated for genetic integration and expression [251,261]. One neutral site on pCC5.2 was used for cloning the limonene synthase genes from Mentha spicata or Citrus limon, which directed the production of limonene [262]. Interestingly, the production of fluorescent proteins directed from neutral sites in pCC5.2 or pCA2.4 were, respectively, 14- or 100-fold higher than those observed after chromosomal integration [249,261,263,264]. These data are consistent with the finding that the endogenous small plasmids have a higher copy number than the chromosome [168]. These findings suggest that to be well-expressed genes should be cloned preferentially in a small endogenous plasmid than in the chromosome, but this assumption remain to be verified with other genes.

Table 1. Literature on the utilization of neutral chromosomal cloning sites in Synechocystis PCC 6803.

\begin{tabular}{|c|c|}
\hline Neutral Site and Objective of the Gene Manipulation & References \\
\hline$p s b A 1:$ a silent gene & [235] \\
\hline Photoproduction of extra bicarbonate transporters to increase biomass & [265] \\
\hline Increase carbon import to improve growth & [266] \\
\hline Photoproduction of isobutanol & [267] \\
\hline psbA2 (slr1311): gene encoding the D1 protein of the PSII & [259] \\
\hline Photoproduction of zeaxanthin & [268] \\
\hline Analysis of a thioredoxin-interacting LuxR-like regulator & [269] \\
\hline Photoproduction of beta-caryophyllene & [270] \\
\hline Photoproduction of D1 protein of the PSII & [271] \\
\hline Photoproduction of polyhydroxybutyrate (PHB) biodegradable bioplastics & [272] \\
\hline Photoproduction of isoprene & [273-277] \\
\hline Photoproduction of lipids & [278] \\
\hline Photoproduction of aromatic amino-acids & [279] \\
\hline Photoproduction of tryptophan & [280] \\
\hline Analysis of endogenous flavodiiron proteins & {$[281,282]$} \\
\hline \multicolumn{2}{|l|}{ cpcB: phycocyanin synthesis gene } \\
\hline Photoproduction of isoprene & {$[283,284]$} \\
\hline Photoproduction of geranyllinalool & [285] \\
\hline
\end{tabular}


Table 1. Cont.

\begin{tabular}{|c|c|}
\hline Neutral Site and Objective of the Gene Manipulation & References \\
\hline \multicolumn{2}{|l|}{ glpK, the gene encoding the glycerol kinase enzyme } \\
\hline Photoproduction of ipid & [286] \\
\hline \multicolumn{2}{|l|}{ Combination $p s b A 2$ and $c p c B$} \\
\hline Cloning of various genes for the photoproduction of isoprene & [287] \\
\hline Photoproduction of $\beta$-phellandrene & [288-293] \\
\hline slr0646 encoding the PBP5 dispensable penicillin binding protein & [294] \\
\hline Photoproduction of the p-coumaric acid & [295] \\
\hline \multicolumn{2}{|l|}{$n d h B$ (sll0223): encoding subunit 2 of the NAD(P)H-dehydrogenase } \\
\hline Analysis of the circadian expression of the DnaK (heat-shock protein) encoding gene & [296] \\
\hline Construction of bioluminescent reporter strains for metal detection & [297] \\
\hline Analysis of the light regulation of the photosystem I genes & [298,299] \\
\hline $\operatorname{slr0168}$ & [220] \\
\hline Analysis of tolerance to stresses & [300-302] \\
\hline Analysis of endogenous and heterologous $\mathrm{Fe}-$ or $\mathrm{Cu} / \mathrm{Zn}$ superoxide dismutase & [302] \\
\hline Promoter analysis & [303] \\
\hline Analysis of fatty-acids synthesis & [304] \\
\hline Photoproduction of ethylene & {$[305,306]$} \\
\hline Photoproduction of lactate & [307-310] \\
\hline Photoproduction of 2,3-butanediol & [311] \\
\hline Photoproduction of sucrose & [312] \\
\hline Development of a marker-less gene replacement tool & [313] \\
\hline Photoproduction of fatty alcohol & [314] \\
\hline Photoproduction of isoprene & [275] \\
\hline Photoproduction of ethanol & [315-317] \\
\hline Photoproduction of glycerol & [318] \\
\hline Photoproduction of $n$-butanol & [319] \\
\hline Analysis of the regulation of Rubisco & [320] \\
\hline Promoter analysis & [321] \\
\hline Photoproduction of 1,2-propanediol & [322] \\
\hline Analysis of alka(e)ne turnover & [323] \\
\hline Photoproduction of mannitol & [324] \\
\hline Photoproduction of bisabolene & [325] \\
\hline \multicolumn{2}{|l|}{ slr0168 and $\operatorname{slr} 1193$} \\
\hline Photoproduction of ethanol & [326] \\
\hline \multicolumn{2}{|l|}{ slr0168 and slr1556 } \\
\hline Photoproduction of alkanes & [327] \\
\hline \multicolumn{2}{|l|}{$n d h B$ and $\operatorname{slr} 0168$} \\
\hline Photoproduction of ethanol & [315] \\
\hline \multicolumn{2}{|l|}{$p s b A 1$ and $\operatorname{slr} 0168$} \\
\hline Analysis of promoters & [328] \\
\hline \multicolumn{2}{|l|}{$p s b A 2$ and $\operatorname{slr} 0168$} \\
\hline Photoproduction of fatty-acids & [329] \\
\hline Analysis of the cyanobacterial iron superoxide dismutase SOD & [302] \\
\hline Photoproduction of ethylene & [330] \\
\hline phaCE genes operating in the synthesis of polyhydroxybutyrate (PHB) biodegradable bioplastics & [331] \\
\hline Photoproduction of acetone & [332] \\
\hline
\end{tabular}


Table 1. Cont.

\begin{tabular}{|c|c|}
\hline Neutral Site and Objective of the Gene Manipulation & References \\
\hline \multicolumn{2}{|l|}{ Intergenic region between slr2030 andslr2031 } \\
\hline Analysis of glutathione synthesis & [333] \\
\hline Analysis of heme oxygenase encoding genes & [334] \\
\hline Photoproduction of poly-hydroxybutyrate (PHB) biodegradable bioplastics & [335] \\
\hline Analysis of Flv3 flavodiiron protein & [336] \\
\hline Photoproduction of pinene & [337] \\
\hline Analysis of promoters and ribosome binding sites & [338] \\
\hline Development of the CRISPR technologies for gene deletion or silencing & [339] \\
\hline Photoproduction of ethylene & [340] \\
\hline \multicolumn{2}{|l|}{ slr0846 and slr2030-slr2031 intergenic region } \\
\hline Photoproduction of glutamate, linalool, and valencene & [341] \\
\hline \multicolumn{2}{|l|}{ Intergenic regions between sll0821-slr0846 and slr2030-slr2031 } \\
\hline Photoproduction of limonene & [342] \\
\hline \multicolumn{2}{|l|}{ slr0168 and slr1704-sll1575 intergenic region } \\
\hline Photoproduction of 3-hydroxypropionic acid & [343] \\
\hline \multicolumn{2}{|l|}{ slr0168, psbA2, and slr2030-Slr2031 intergenic region } \\
\hline Photoproduction of the manoyl oxide terpene & [344] \\
\hline Photoproduction of ethanol and butanol & [345] \\
\hline $\begin{array}{l}\text { Intergenic regions between } \\
\text { slr1495-sll1397, slr1362-sll1274, slr1828-sll1736, and slr1992-phaA2 }\end{array}$ & \\
\hline Photoproduction of 3-hydroxybutyrate the precursor of the synthesis of PHB & [346] \\
\hline
\end{tabular}

The chromosomal cloning sites, written in bold cases are highlighted in grey color. The $c p c B$ gene operates in the synthesis of the phycocyanin pigment. The $g l p K$ gene encodes the glycerol kinase. slr0646 encodes the PBP5 dispensable penicillin binding protein [294]. The gene $n d h B$ (sll0223) encodes a subunit of a NAD(P)H-dehydrogenase enzyme. The gene slr0168 has no known function [220]. The phaCE genes operate in the synthesis of polyhydroxybutyrate (PHB) biodegradable bioplastics [331]. While $p s b A 1$ is a silent gene [235], its homologue $p s b A 2$ (slr1311) encodes the D1 protein of the photosystem II [259].

In Synechococcus PCC 7942 (Table 2), the most frequently employed chromosomal neutral sites are NSI (GenBank accession $n^{\circ}$ U30252), NSII (GenBank accession U44761) [253]), and NSIII (GenBank accession ABB56771.1) [254,255].

Table 2. Literature on the utilization of neutral chromosomal cloning sites in Synechococcus PCC 7942.

\begin{tabular}{|c|c|}
\hline Neutral Site and Objective of the Gene Manipulation & References \\
\hline \multicolumn{2}{|l|}{ NSI } \\
\hline Photoproduction of 1,2-propanediol & [347] \\
\hline Photoproduction of glycerol & [348] \\
\hline Photoproduction of lactate & [349] \\
\hline Photoproduction of succinate & {$[350]$} \\
\hline Photoproduction of ethylene & [351] \\
\hline Photoproduction of ethanol & [352] \\
\hline \multicolumn{2}{|l|}{ NSII } \\
\hline Photoproduction of free fatty acids & [353-355] \\
\hline Photoproduction of B12 vitamin & [356] \\
\hline \multicolumn{2}{|l|}{$\begin{array}{ll}\text { NSIII } \\
\end{array}$} \\
\hline Photoproduction of isobutyraldehyde & [357] \\
\hline Photoproduction of carboxysome proteins & [358] \\
\hline
\end{tabular}


Table 2. Cont

\begin{tabular}{|c|c|}
\hline Neutral Site and Objective of the Gene Manipulation & References \\
\hline \multicolumn{2}{|l|}{ NSI and NSII } \\
\hline Analysis of the circadian rhythm & [359] \\
\hline Photoproduction of isobutyraldehyde & [360] \\
\hline Photoproduction of 1-butanol & {$[361,362]$} \\
\hline Analysis of carboxysomes & {$[363,364]$} \\
\hline Photoproduction of isopropanol & [364] \\
\hline Photoproduction of isobutanol & [365] \\
\hline Photoproduction of 3-hydroxypropionic acid & [366] \\
\hline Photoproduction of 1,3-propanediol & [367] \\
\hline Photoproduction of amorphadiene and squalene & [368] \\
\hline Photoproduction of limonene & [369] \\
\hline Photoproduction of acetone & [370] \\
\hline Photoproduction of isoprene & [371] \\
\hline Analysis of gene-expression control systems & [372] \\
\hline Photoproduction of 2,3-butanediol & [373] \\
\hline Photoproduction of farnesene & {$[374,375]$} \\
\hline Photoproduction of lactate & [376] \\
\hline \multicolumn{2}{|l|}{ NSI and NSIII } \\
\hline Photoproduction of biomass and sucrose export & [377] \\
\hline Photoproduction of a synthetic $\mathrm{CO}_{2}$-fixing photorespiratory bypass & [378] \\
\hline Photoproduction of 2,3 butanediol & [379] \\
\hline Photoproduction of amorphadiene or squalene & [380] \\
\hline \multicolumn{2}{|l|}{ NSI, NSII, and NSIII } \\
\hline Overproduction of transporters to facilitate sugar export & [254] \\
\hline Promoter analysis & [381] \\
\hline Photoproduction of polyketides & [382] \\
\hline Analysis of the influence of pilus biogenesis on the natural transformation & [229] \\
\hline \multicolumn{2}{|l|}{$p s b A 1$} \\
\hline Photoproduction of ethylene & [383] \\
\hline \multicolumn{2}{|l|}{$\operatorname{glgc}$} \\
\hline Photoproduction of isobutanol & [366] \\
\hline Intergenic region Synpcc7942_0893 and Synpcc7942_0894 & \\
\hline Photoproduction of 2,3-butanediol & [384] \\
\hline
\end{tabular}

The chromosomal cloning sites, written in bold cases are highlighted in grey color.

In Synechococcus PCC 7002, the few neutral cloning sites employed (Table 3) are mainly the chromosomal genes $g l p K$, which had been thought for some time to harbor a frameshift mutation preventing the production of a functional glycerol kinase enzyme [385], and $\operatorname{acs} A$, which encodes an acetyl-CoA ligase, the inactivation of which conferred resistance to (3-hydroxy)propionate [386]. 
Table 3. Literature on the utilization of chromosomal neutral cloning sites in Synechococcus PCC 7002.

\begin{tabular}{cc}
\hline Neutral Cloning Sites & Objective of the Gene Manipulation and References \\
\hline $\begin{array}{c}\text { klpK (SYNPCC7002_A2842) encoding the glycerol } \\
\text { kinase [385,386] }\end{array}$ & $\begin{array}{c}\text { Removal of carboxysomes for containment of genetically } \\
\text { modified strains [387] }\end{array}$ \\
\hline $\begin{array}{c}a c s A \text { gene (SYNPCC7002_A1838) encoding an acetyl-CoA ligase } \\
\text { and } g l p K\end{array}$ & Analysis of an organic acid-based counter selection system [386] \\
\hline $\begin{array}{c}\text { Integration between } \\
\text { SYNPCC7002_A0935 and SYNPCC7002_A0936 } g l p K\end{array}$ & Analysis of promoters and ribosome binding sites [388] \\
\hline
\end{tabular}

$g l p K$ and desB (SYNPCC7002_A0159 encoding a $\omega 3$ acyl-lipid desaturase [389] and integration between SYNPCC7002_A0935 and SYNPCC7002_A0936

Development of genetic tools [390]

glpK and integration between A0935-A0936 Engineering a strain for melamine degradation [391]

Intergenic regions between

SYNPCC7002_A0932 and SYNPCC7002_A0933,

SYNPCC7002_A1202 and SYNPCC7002_A1203,

SYNPCC7002_A1778 and SYNPCC7002_A1779

Development of genetic tools [257]

SYNPCC7002_A1838, SYNPCC7002_A2542, and SYNPC-

C7002_A2842

Photoproduction of L-lysine [392]

The inactivation of the glycerol kinase $g l p K$ gene (SYNPCC7002_A2842), which was mistakenly annotated as having a frameshift mutation preventing the production of a functional protein [385], has no influence on the physiology of Synechococcus PCC 7002 [386]. Similarly, the inactivation of desB (SYNPCC7002_ A0159, w3 acyl-lipid desaturase) has no detrimental influence at temperature above 22 ${ }^{\circ} \mathrm{C}[389]$. The inactivation of the $a c s A$ gene (SYNPCC7002_A1838) encoding an acetyl-CoA ligase confers resistance to 3-hydroxypropionate and propionate [386].

\subsection{Development of Transformable Shuttle Vectors Based on the Endogenous Plasmids of} Synechocystis PCC 6803, Synechococcus PCC 7942, and Synechococcus PCC 7002

Because transformation and autonomously replicating plasmids have played a crucial role for gene manipulation in Escherichia coli, several groups tried to introduce an E. coli plasmid (pBR322 and its pUC derivatives) into cyanobacteria by transformation. All attempts were unsuccessful $[163,178,231]$, in spite of a single report [393] that was never confirmed thereafter. These findings indicated that these E. coli plasmids are not able to replicate in cyanobacteria. Consequently, chimeric plasmids capable to replicate both in E. coli and a transformable cyanobacteria were constructed by cloning a small (cryptic) cyanobacterial plasmid (or a part of it) into an E. coli plasmid [394]. This approach was initiated in Synechococcus PCC 7942 using its smaller $7.84 \mathrm{kbp}$ endogenous plasmid [182,395]. Then, the transformation efficiency was increased by plating the transformation mixture (recipient cells plus transforming DNA) on solid medium and incubating the plate in standard condition for $24 \mathrm{~h}$ prior to adding the selective antibiotic underneath the agar of the plate [183]. The transformation was more efficient when the recipient cyanobacterial cells were taken at the transition from the first to the second exponential growth phases [183], similarly to what has been observed for the transformation with linear chromosomal DNA [226]. The influence of the growth phase on transformation, which was not confirmed by other workers [396], was also observed in Synechocystis PCC 6803 [163].

Synechococcus PCC 7942 was found to be transformed more efficiently by chimericplasmid DNA isolated directly from this cyanobacterium rather than from E. coli [182]. This was explained by assuming that Synechococcus PCC 7942 and E. coli DNA are differently modified, for instance, by dam- or dcm-like DNA methylation systems [182]. Similarly, Synechococcus PCC 7002 was more efficiently transformed by its chimeric plasmid when it had been isolated directly from this host rather than from E. coli [397]. Furthermore, the elimination from this Synechococcus PCC 7002 biphasic plasmid of the AvaI restriction site (cleaved by the AvaI-isoschizomer AquI endonuclease of Synechococcus PCC 7002) strongly increased the efficiency of transformation to Synechococcus PCC 7002 [397]. The importance 
of DNA modification for genetic transformation and cell fitness of cyanobacteria were firmly established in Synechocystis PCC 6803 [398-401].

The biphasic plasmids autonomously replicating in E. coli and a specific cyanobacterium were improved by several groups through the addition of restriction sites for facile gene cloning and/or several antibiotic-resistance genes for effective selection in Synechococcus PCC 7942 [402-404], Synechocystis PCC 6803 [163], and Synechococcus PCC 7002 [405]. These shuttle vectors were used for complementation analyses selecting for both the antibiotic resistance of the vector and the wild-type phenotype [406]. This approach allowed the identification and analysis of genes encoding the key stress-defense proteins RecA [405] and the Mn SOD [407]. One Synechocystis PCC 6803 shuttle vector served for analyzing the activity of several E. coli promoters, such as the tac promoter which appeared to be as effective in Synechocystis PCC 6803 as in E. coli [408]. This promoter-probe vector was also used to show that the lambda phage $C_{857}$ gene (encoding a temperature sensitive repressor) and associated $\mathrm{P}_{R}$ promoter can be employed for strong and tight temperature-controlled gene expression [408]. Latter these gene expression devices were also shown to work well in other cyanobacteria $[409,410]$.

The Synechococcus PCC 7002 and Synechococcus PCC 7942 shuttle vectors were employed for the production of heterologous larvicidal proteins in cyanobacterial cells, which turned out to be toxic when ingested by mosquito larvae [411,412]. Other studies reported the cloning of heterologous genes in Synechococcus PCC 7942 to increase its resistance to cadmium [413] or salt [414,415]. Similarly, the Zymomonas mobilis genes encoding the pyruvate decarboxylase $(p d c)$ and alcohol dehydrogenase II ( $a d h)$ were cloned into a Synechococcus PCC 7942 shuttle vector to engineer an ethanol producer [416]. The same strategy of cloning heterologous genes into a shuttle vector was used to generate a Synechococcus PCC 7942 recombinant strain for the production of ethylene [417-419]. Chimeric shuttle vectors were also used to overexpress endogenous metabolic genes to improve $\mathrm{CO}_{2}$-fixation and/or biomass production in Synechococcus PCC 7942 [420].

\subsection{The Chimeric Shuttle Vectors Based on an Endogenous Cyanobacterial Plasmid Tend to Have a Narrow-Host-Range of Replication}

The abovementioned biphasic shuttle plasmids based on a cyanobacterial replicon appeared to replicate in one or a few genetically manipulable cyanobacteria. For examples, the Synechococcus PCC 7942 chimeric plasmids could not transform Synechocystis PCC 6803 [163], and reciprocally, the Synechocystis PCC 6803 shuttle vectors could not transform Synechococcus PCC 7942 [163]. In contrast, a shuttle vector based on an endogenous plasmid from Synechococcus PCC 7942 was shown to replicate in Anabaena PCC 7120, but not in Synechocystis PCC 6803 [421].

Plasmid vectors that can be transferred to, but cannot replicate in, a host are interesting for transporting DNA that must either transpose (e.g., a transposon, useful for random mutagenesis) or by homologous recombination in order to be stably maintained.

7.6. The Development of Autonomously Replicating Vectors Derived from the Broad-Host-Range Conjugative Plasmid RSF1010 Has Boosted the Genetics of Cyanobacteria

The interest of chimeric plasmid vectors that uses two narrow-host-range replicons originating from E. coli and a cyanobacterium is limited by the fact that they can shuttle only from E. coli to mostly the corresponding cyanobacterium. Such narrow-host-range vectors are not suitable for rapid tests and comparisons of a gene function in diverse cyanobacterial hosts to select (and engineer) a cyanobacterial chassis for an effective photosynthetic production of an industrially interesting chemical. Thus, several groups turned their attention to the naturally-occurring RSF1010 plasmid [422], a member of the incQ incompatibility group that replicates in a wide range of Gram-negative bacterial genera (cyanobacteria are also Gram-negative), including Acetobacter, Acinetobacter, Agrobacterium, Alcaligene, Azotobacter, Escherichia, Klebsiella, Methylophilus, Providencia, Pseudomonadales, Rhizobiaceae, Rhodopseudomonas, and Salmonella SP- and Serratia. The value of RSF1010 as a shuttle vector is further enhanced by its ability to be transferred by conjugation from 
an E. coli strain also carrying a self-transmissible (incP group) plasmid, such as RP4. The RSF1010-derived plasmids can be used to carry novel genetic information to those bacteria that are not capable of transformation [423-425].

RSF1010 and its derivatives were shown to be efficiently transferred by conjugation from E. coli to cyanobacteria where they replicate autonomously, even though they contain no cyanobacterial replicon. These cyanobacteria were, namely, Synechocystis PCC 6803 [426], Synechococcus NKBG15041C, Pseudanabaena NKBG040605C [427], Synechocystis PCC 6714, Synechococcus strains PCC7942 and PCC6301 [428], Thermosynechococcus elongatus PB1 [429], marine Synechococcus strains sp. WH7803, WH8102 and WH8103 [430], Gloeobacter violaceus PCC 7421 [431,432], Prochlorococcus MIT9313 [433], Nostoc (Anabaena) PCC 7120, Nostoc punctiforme ATCC29133 (also registered as PCC 73102) [255,434,435], Leptolyngbya BL0902 [436] and Cyanothece PCC 7425 [410].

Shortly after, the Synechocystis PCC6803 pioneering report [426], RSF1010 was used for the development of the first conjugative plasmid vector for promoter analysis [409] and regulated protein production in cyanobacteria [437]. The promoter-probe vector used the promoter-less chloramphenicol-acetyl-transferase (cat) gene as the reporter. When expressed by a studied promoter, cat directs the production of the CAT enzyme, the activity of which can be monitored by a spectrophotometric assay and confers the resistance to chloramphenicol [409]. This vector was used for the analysis of constitutive or regulated promoters [126,438,439] and references therein. The conditional expression vector [437] harbors the lambda-phage gene ${ } I_{857}$ encoding a temperature-sensitive repressor that tightly controls the activity of the otherwise strong $p_{R}$ promoter. Together these elements allow a tight temperature-controlled expression of the studied genes (no production of the corresponding proteins at temperatures below $30{ }^{\circ} \mathrm{C}$, moderate level at $34-36{ }^{\circ} \mathrm{C}$, and high production at $39-40^{\circ} \mathrm{C}$ ). This vector and its derivative harboring the $g f p$ gene encoding the green-fluorescent reporter protein have been employed for proteins involved in photosynthesis [125], response to stress [34], cell division [440-442], and biogenesis of the carboxysome [410].

Other RSF1010-derived plasmids vectors have been used to analyze ribosome binding sites and transcription terminators [264], light-emitting proteins GFP, YFP (yellowfluorescent protein), and luciferase [255,264,432,434]. RSF1010-derived vectors were also employed to analyze the role of carbon stores glycogen and PHB (polyhydroxybutyrate) in the tolerance to stress [443] and systems for the control of gene expression (in Synechococcus PCC 7942) [372], as well as various proteins such as the Synechocystis PCC 6803 photolyase enzyme PhrA [444] and to improve carbon fixation [445].

RSF1010 derivative plasmids were also employed in many works aiming at producing biotechnologically interesting products including bisabolol and patchoulol [446], ethanol [447], ethylene [306,340,448-450], erythritol [451], hydrogen [452,453], isobutanol [454,455], lactate [308], limonene [410], n-butanol [319], and triterpenes (lupeol, marnerol, and hydroxymarnerol) [456].

Interestingly, in Synechocystis PCC 6803, it has been shown that RSF1010 and the pCC5.2 endogenous plasmid could be used for cloning, respectively, two pentose phosphate pathway native genes and the limonene synthase genes (lims) from either Mentha spicata or Citrus limon, which directed the production of limonene [262].

\section{Interest and Limitation of the CRISPR/Cas Genome Editing Technology}

Recently, the CRISPR/Cas system (CRISPR stands for clustered regularly interspaced short palindromic repeats and Cas for CRISPR-associated endonuclease) has facilitated the way genomes are edited in cyanobacteria, such as Synechocystis PCC 6803, Synechococcus PCC 7942, Synechococcus PCC 7002, Synechococcus UTEX 2973, and the filamentous strain Nostoc (Anabaena) PCC 7120 (for reviews see [80,83,84,339,457]. Briefly, CRISPR/Cas genome editing systems exploit the Class II family of Cas endonucleases, which have a site-specific RNA-guided DNA cleavage activity. As compared to the well-established gene deletions techniques based on homologous DNA recombination, the interest of 
the CRISPR/Cas system are (i) CRISPR/Cas systems can allow the engineering of nontransformable cyanobacteria, providing they can be manipulated by conjugation; (ii) a marker-less mutation is generated at the DNA target site; and (iii) multiple DNA loci can be modified simultaneously, by co-expressing the appropriate guide RNAs and editing templates.

The limitation of the CRISPR/Cas technology are the potential toxicity of the Cas DNase and the time required to eliminate the CRISPR/Cas plasmid vector from the generated mutant. However, this curing step can be accelerated by the presence of a negative selection marker in the CRISPR/Cas vector [80].

A variant of the CRISPR/Cas system, the CRISPRi (CRISPR interference) system that make use of DNase-inactive variants of Cas, is especially relevant to repress (fully or not) the transcription of studied genes, including the essential ones that cannot be deleted. This strategy was used for the targeted repression of vital genes to arrest growth and increase carbon partitioning and biofuel titers in Synechocystis PCC 6803 [345]. The CRISPRi technology was also employed to generate mutants with increased yields of growth and lactate secretion [458].

\section{Responses to Stresses: The Recent Progress in Omics Technics Are Limited by the Large Number of Genes of Still Unknown Function}

Because of their oxygenic photosynthesis, which triggered oxygen-promoted changes in metal availability, and the fact that they colonized most aquatic biotopes of our planet, cyanobacteria have always been challenged by changes in light, metals, and nutrients availabilities [28]. The responses to these stresses have been well studied with omics techniques that measure the changes in abundance of transcripts (transcriptomics), proteins (proteomics), or metabolites (metabolomics). The available genome sequences facilitate the use of transcriptomic and proteomic approaches.

Initially, transcriptomics focused on Synechocystis PCC 6803, because its genome has been the first to be fully sequenced [48] and used to develop the first commercially available DNA microarrays (IntelliGene ${ }^{\mathrm{TM}}$ CyanoCHIP; Takara Bio Inc., Shiga, Japan), which only comprised probes for protein-coding genes deposited on a glass support. These CyanoCHIP were used to the transcriptional responses to high light [459], inhibitors of photosynthesis [460], depletion of the LexA regulator [90], salt [461-464], cold stress [465], acid stress [466,467], heat shock [468-470], osmotic stress [465,471,472], oxidative stresses triggered by methyl viologen [473], or $\mathrm{H}_{2} \mathrm{O}_{2}$ [474,475], Cd-, Fe-, or Zn-stresses [474].

Later, several genome-wide Synechocystis PCC 6803 microarrays were also developed, based on long oligonucleotide probes (60- to 70-mer) spotted on a glass support. Such oligonucleotides-based microarrays circumvented the labor-intensive and error-prone steps of probe amplification and purification. They were used to study cell responses to sulfur starvation [476] and the deletion of the AbrB2 transcription regulator [477].

As an alternative to microarray analyses, which are based on hybridization of mRNA to DNA probes, the direct sequencing of RNA (an approach designated as RNA-Seq) was adapted to cyanobacteria [478]. RNA-Seq rapidly became the standard method for cyanobacterial transcriptomics [250,479]. It revealed that the Synechocystis PCC 6803 transcriptome includes more than 4000 transcriptional units, half of which representing small RNAs (sRNAs), which often harbor a small protein-coding sequence of less than 100 amino acid residues, and non-coding RNAs (ncRNAs) [480]. These ncRNAs could not be detected by DNA microarrays that only comprised probes for protein-coding genes. The vast majority of ncRNAs are still uncharacterized, and most of them are antisense transcripts (asRNAs). The phylogenetic conservation of ncRNAs across genomes of relatively distant cyanobacteria and their regulated transcription in response to major stresses, such as, light, iron, carbon, or nitrogen availability, nitrogen starvation [481], and butanol or ethanol stress [482], suggest that many ncRNAs may be involved in regulation [250,479].

Proteomics was also used to study the cyanobacterial responses to stresses, again starting with Synechocystis PCC 6803 [483], the genome of which is predicted to contain 3672 putative open reading frames (ORFs, i.e., protein coding sequences). Of these, 
3264 and 408 ORFs are located on the chromosome and the seven endogenous plasmids, respectively [484]. Traditionally, two-dimensional polyacrylamide gels (2D-PAGE) and utilization of different fluorescence dyes (difference gel electrophoresis; 2D-DIGE) were employed to estimate concentrations for each protein between stress versus unstressed conditions. Later strategies took advantage of the sensitivity of liquid chromatography (LC), coupled with tandem mass spectrometry (MS), known as LC-MS/MS, for quantitative proteomic analysis, using different tags such as the isobaric tags for relative and absolute quantitation (iTRAQ)-based quantitative proteomics [485,486]. This quantitative technique became the dominant proteomics method for the identification of differentially expressed proteins of Synechocystis PCC 6803 [485-488].

These proteome techniques were employed to study the responses to cold [489]; copper [490]; $\mathrm{CO}_{2}$ limitation [491]; high light [492]; high or low temperature [469,492-494]; high or low $\mathrm{pH}$ [495-497]; nitrogen-, phosphate, or sulfate-starvations [481,498,499]; metal stress [498,500,501]; salt stress [502-507]; and UV-B stress [508]. They also served to study the tolerance of Synechocystis PCC 6803 to butanol, ethanol, or hexane biofuels [488,509-512], as well as to analyze cyanobacterial strains engineered for the production of butanol [511], ethanol [510], hexane [509], or 3-hydroxypropionic acid [513].

In addition to the quantification of proteins, proteome methods can be used to identify protein modifications, such as glutathionylation [40], lysine malonylation [514], lysine methylation [515], phosphorylation [516-518], which are potentially involved in controlling protein activities.

However, our current understanding of the transcriptome and proteome responses to various challenges is limited by the fact that a large number of the responsive genes or proteins have still an unknown function.

In addition to transcriptomics and proteomics, metabolomics that focuses on lowmolecular-weight metabolites provides the most straightforward characterization of metabolic responses to environmental changes. Compared to other omics studies, a few metabolomic research studies have been performed in cyanobacteria, and again Synechocystis PCC 6803 has been the most studied model. As many metabolites turn over quickly, fast sampling through fast culture filtration appeared to be very important in metabolomic analyses $[519,520]$. The combination of gas chromatography or liquid chromatography with mass spectrometry permits quantitative analysis of more than 100 metabolites in cyanobacterial cells. In addition to metabolomics, which seeks comprehensive profiling of predominantly intra-organism compounds, volatilomics assesses those compounds released by an organism: the key components of chemically mediated inter-organismal communication [521,522]. The field of volatilomics grew out as advances in collection methods of volatile organic compounds and gas chromatography coupled with mass spectrometry.

Finally, in several studies, transcriptomics, proteomics, and/or metabolomics were integrated to better analyze the responses of Synechocystis PCC 6803 to environmental conditions [492,497,523-529], as well as the production of [530] or the tolerance to chemicals [531]. In some cases, it appeared that omics data at different levels do not necessarily correlate a finding that can be explained by regulations occurring at the levels of gene expression $[6,93,479,532-534]$ and/or enzyme stability and activity [40,483,527].

\section{Conclusions}

Cyanobacteria are a widely-diverse photosynthetic prokaryotes of wide interest for basic and applied sciences. So far, cyanobacterial research has focused primarily on a few models, such as the three unicellular non-nitrogen fixing species Synechocystis PCC 6803, Synechococcus PCC 7942, and Synechococcus PCC 7002, which are straightforward to culture under laboratory conditions, easily amenable to genetic modification and can be frozen for long-term storage. Extensive "omics" data sets and many genetic tools and genomescale metabolic models (GSM) have been generated to guide the engineering of these model cyanobacteria for the photosynthetic production of biotechnologically interesting chemicals. Interestingly, it has been put forward that GSM should take into account 
and describe photon absorption and light-shading thereby addressing the challenge of accurately modeling light as a metabolite $[535,536]$. In addition, GSM should be validated with experimental data obtained after measurement of metabolic fluxes and metabolic pool sizes $[80,86,87,536]$. However, omics data interpretation and GSM metabolic designs are based on our currently limited understanding of the genotype-phenotype relationships of cyanobacteria. Thus, to generate robust and predictive GSM models of the cyanobacterial metabolism, it is important to continue the analysis of Synechocystis PCC 6803, Synechococcus PCC 7942 and Synechococcus PCC 7002, and increase the efforts to

(i) verify the function of numerous genes that have been annotated merely by sequence analogy with those genes characterized only in intensively studied nonphotosynthetic models (E. coli, yeast, etc.), which may have a different function in cyanobacteria;

(ii) and analyze the specificity/redundancy of multiple gene families;

(iii) characterize the function of the large number of as yet unknown genes and non-coding RNAs;

(iv) identify the comprehensive set of genes that are essential to the growth of cells incubated in well-defined conditions.

Furthermore, most of the attempts to reprogram Synechocystis PCC 6803, Synechococcus PCC 7942, or Synechococcus PCC 7002 for the photoproduction of chemicals have focused on increasing product synthesis by small-scale cultures growing under laboratory conditions because most academic researchers lack access to large-scale production systems that are necessary to evaluate the potential of engineered strains under realistic industrial conditions.

Moreover Synechocystis PCC 6803, Synechococcus PCC 7942, and Synechococcus PCC 7002 represent only a limited part of the wide biodiversity of cyanobacteria. This arguably limits fundamental discovery and applied research towards wider commercialization. Thus, new phylogenetically-distant candidate cyanobacteria should be isolated and developed from diverse environments with a robust growth and high tolerance to local conditions, so as to be used as chassis for the photosynthetic production of high-value chemicals in diverse industrial sites. We think that the genetic modifiability of such candidate strains using the conjugative transfer of RSF1010-derived broad-host-range plasmids will be key for such works.

To summarize, we recommend to strengthen the communication between academic researchers, who know well cyanobacteria and can manipulate them, but have a limited access to large photobioreactors and industrial partners, who attempt to use cyanobacteria to produce interesting chemicals at reasonable costs, but often lack knowledge on cyanobacterial genetics, physiology, and metabolism. Moreover, to minimize operation costs we need to develop robust cyanobacteria capable to grow on industrial waters and fumes, in huge photobioreactors, as well as well as efficient technologies to harvest the end products.

Author Contributions: Conceptualization, C.C.-C. and F.C.; writing—original draft preparation, F.C., C.C.-C., and V.B.-G.; writing-review and editing, F.C., C.C.-C., and V.B.-G.; supervision, F.C. and C.C.-C.; project administration, F.C. and C.C.-C.; funding acquisition, F.C. and C.C.-C. All authors have read and agreed to the published version of the manuscript.

Funding: This research was funded in part by the ANR CalvinDesign (ANR-17-CE05-0001).

Conflicts of Interest: The authors declare no conflict of interest. The funders had no role in the design of the study; in the collection, analyses, or interpretation of data; in the writing of the manuscript; or in the decision to publish the results. 


\section{References}

1. Soo, R.M.; Hemp, J.; Hugenholtz, P. Evolution of photosynthesis and aerobic respiration in the cyanobacteria. Free Radic. Biol. Med. 2019, 140, 200-205. [CrossRef]

2. Garcia-Pichel, F.; Zehr, J.P.; Bhattacharya, D.; Pakrasi, H.B. What's in a name? The case of cyanobacteria. J. Phycol. 2020, 56, 1-5. [CrossRef]

3. Hamilton, T.L.; Bryant, D.A.; Macalady, J.L. The role of biology in planetary evolution: Cyanobacterial primary production in low-oxygen Proterozoic oceans. Environ. Microbiol. 2016, 18, 325-340. [CrossRef]

4. Ponce-Toledo, R.I.; Deschamps, P.; López-García, P.; Zivanovic, Y.; Benzerara, K.; Moreira, D. An Early-Branching Freshwater Cyanobacterium at the Origin of Plastids. Curr. Biol. 2017, 27, 386-391. [CrossRef]

5. Ducat, D.C.; Way, J.C.; Silver, P.A. Engineering cyanobacteria to generate high-value products. Trends Biotechnol. 2011, 29, 95-103. [CrossRef]

6. Veaudor, T.; Blanc-Garin, V.; Chenebault, C.; Diaz-Santos, E.; Sassi, J.F.; Cassier-Chauvat, C.; Chauvat, F. Recent advances in the photoautotrophic metabolism of cyanobacteria: Biotechnological implications. Life 2020, 10, 71. [CrossRef] [PubMed]

7. Mills, L.A.; McCormick, A.J.; Lea-Smith, D.J. Current knowledge and recent advances in understanding metabolism of the model cyanobacterium Synechocystis sp. PCC 6803. Biosci. Rep. 2020, 40. [CrossRef]

8. Garcia-Pichel, F.; Belnap, J.; Neuer, S.; Schanz, F. Estimates of global cyanobacterial biomass and its distribution. Arch. Hydrobiol. Suppl. Algol. Stud. 2009, 109, 213-227. [CrossRef]

9. Chang, A.C.G.; Chen, T.; Li, N.; Duan, J. Perspectives on endosymbiosis in coralloid roots: Association of cycads and cyanobacteria. Front. Microbiol. 2019, 10. [CrossRef] [PubMed]

10. Cassier-Chauvat, C.; Chauvat, F. Cyanobacteria: Wonderful Microorganisms for Basic and Applied Research. eLS 2018, 1-11. [CrossRef]

11. Cassier-Chauvat, C.; Chauvat, F. Cell division in cyanobacteria. In The Cell Biology of Cyanobacteria; Flores, E., Herrero, A., Eds.; Caister Academic Press: Poole, UK, 2014.

12. Springstein, B.L.; Nürnberg, D.J.; Weiss, G.L.; Pilhofer, M.; Stucken, K. Structural determinants and their role in cyanobacterial morphogenesis. Life 2020, 10, 355. [CrossRef] [PubMed]

13. Chauvat, F.; Corre, B.; Herdman, M.; Joset-Espardellier, F. Energetic and metabolic requirements for the germination of akinetes of the cyanobacterium Nostoc PCC 7524. Arch. Microbiol. 1982, 133, 44-49. [CrossRef]

14. Herrero, A.; Stavans, J.; Flores, E. The multicellular nature of filamentous heterocyst-forming cyanobacteria. FEMS Microbiol. Rev. 2016, 40, 831-854. [CrossRef]

15. Dittmann, E.; Gugger, M.; Sivonen, K.; Fewer, D.P. Natural Product Biosynthetic Diversity and Comparative Genomics of the Cyanobacteria. Trends Microbiol. 2015, 23, 642-652. [CrossRef]

16. Cassier-Chauvat, C.; Dive, V.; Chauvat, F. Cyanobacteria: Photosynthetic factories combining biodiversity, radiation resistance, and genetics to facilitate drug discovery. Appl. Microbiol. Biotechnol. 2017, 101, 1359-1364. [CrossRef]

17. Demay, J.; Bernard, C.; Reinhardt, A.; Marie, B. Natural products from cyanobacteria: Focus on beneficial activities. Mar. Drugs 2019, 17, 320. [CrossRef]

18. Pereira, S.B.; Sousa, A.; Santos, M.; Araújo, M.; Serôdio, F.; Granja, P.; Tamagnini, P. Strategies to obtain designer polymers based on cyanobacterial extracellular polymeric substances (EPS). Int. J. Mol. Sci. 2019, 20, 5693. [CrossRef]

19. Knoot, C.J.; Ungerer, J.; Wangikar, P.P.; Pakrasi, H.B. Cyanobacteria: Promising biocatalysts for sustainable chemical production. J. Biol. Chem. 2018, 293, 5044-5052. [CrossRef]

20. Lin, P.C.; Pakrasi, H.B. Engineering cyanobacteria for production of terpenoids. Planta 2019, 249, 145-154. [CrossRef]

21. Schopf, J.W. The paleobiological record of photosynthesis. Photosynth. Res. 2011, 107, 87-101. [CrossRef] [PubMed]

22. Imlay, J.A. The molecular mechanisms and physiological consequences of oxidative stress: Lessons from a model bacterium. Nat. Rev. Microbiol. 2013, 11, 443-454. [CrossRef] [PubMed]

23. Shimakawa, G.; Matsuda, Y.; Nakajima, K.; Tamoi, M.; Shigeoka, S.; Miyake, C. Diverse strategies of $\mathrm{O}_{2}$ usage for preventing photo-oxidative damage under $\mathrm{CO}_{2}$ limitation during algal photosynthesis. Sci. Rep. 2017, 7. [CrossRef] [PubMed]

24. Diaz, J.M.; Plummer, S. Production of extracellular reactive oxygen species by phytoplankton: Past and future directions. J. Plankton Res. 2018, 40, 655-666. [CrossRef] [PubMed]

25. Narainsamy, K.; Marteyn, B.; Sakr, S.; Cassier-Chauvat, C.; Chauvat, F. Genomics of the Pleïotropic Glutathione System in Cyanobacteria. Adv. Bot. Res. 2013, 65, 157-188.

26. Picciocchi, A.; Saguez, C.; Boussac, A.; Cassier-Chauvat, C.; Chauvat, F. CGFS-type monothiol glutaredoxins from the cyanobacterium Synechocystis PCC6803 and other evolutionary distant model organisms possess a glutathione-ligated [2Fe-2S] cluster. Biochemistry 2007, 46, 15018-15026. [CrossRef] [PubMed]

27. Fahey, R.C. Glutathione analogs in prokaryotes. Biochim. Biophys. Acta Gen. Subj. 2013, 1830, 3182-3198. [CrossRef]

28. Cassier-Chauvat, C.; Chauvat, F. Genomics of the Resistance to Metal and Oxidative Stresses in Cyanobacteria. Stress Environ. Regul. Gene Expr. Adapt. Bact. 2016, 2, 1154-1164.

29. Kammerscheit, X.; Chauvat, F.; Cassier-Chauvat, C. From cyanobacteria to human, MAPEG-type glutathione-S-transferases operate in cell tolerance to heat, cold, and lipid peroxidation. Front. Microbiol. 2019, 10, 2248. [CrossRef]

30. Berndt, C.; Lillig, C.H. Glutathione, Glutaredoxins, and Iron. Antioxid. Redox Signal. 2017, 27, 1235-1251. [CrossRef] 
31. Narainsamy, K.; Farci, S.; Braun, E.; Junot, C.; Cassier-Chauvat, C.; Chauvat, F. Oxidative-stress detoxification and signalling in cyanobacteria: The crucial glutathione synthesis pathway supports the production of ergothioneine and ophthalmate. Mol. Microbiol. 2016, 100, 15-24. [CrossRef]

32. Kammerscheit, X.; Chauvat, F.; Cassier-Chauvat, C. First in vivo evidence that glutathione-s-transferase operates in photooxidative stress in cyanobacteria. Front. Microbiol. 2019, 10, 1899. [CrossRef]

33. Noctor, G.; Mhamdi, A.; Chaouch, S.; Han, Y.; Neukermans, J.; Marquez-Garcia, B.; Queval, G.; Foyer, C.H. Glutathione in plants: An integrated overview. Plant Cell Environ. 2012, 35, 454-484. [CrossRef] [PubMed]

34. Marteyn, B.; Sakr, S.; Farci, S.; Bedhomme, M.; Chardonnet, S.; Decottignies, P.; Lemaire, S.D.; Cassier-Chauvat, C.; Chauvat, F. The Synechocystis PCC6803 MerA-like enzyme operates in the reduction of both mercury and uranium under the control of the glutaredoxin 1 enzyme. J. Bacteriol. 2013, 195, 4138-4145. [CrossRef] [PubMed]

35. Cassier-Chauvat, C.; Chauvat, F. Responses to oxidative and heavy metal stresses in cyanobacteria: Recent advances. Int. J. Mol. Sci. 2015, 16, 871. [CrossRef] [PubMed]

36. Thorsen, M.; Jacobson, T.; Vooijs, R.; Navarrete, C.; Bliek, T.; Schat, H.; Tamás, M.J. Glutathione serves an extracellular defence function to decrease arsenite accumulation and toxicity in yeast. Mol. Microbiol. 2012, 84, 1177-1188. [CrossRef] [PubMed]

37. Przybyla-Toscano, J.; Roland, M.; Gaymard, F.; Couturier, J.; Rouhier, N. Roles and maturation of iron-sulfur proteins in plastids. J. Biol. Inorg. Chem. 2018, 23, 545-566. [CrossRef]

38. Daniel, T.; Faruq, H.M.; Laura Magdalena, J.; Manuela, G.; Christopher Horst, L. Role of GSH and Iron-Sulfur Glutaredoxins in Iron Metabolism-Review. Molecules 2020, 27, 3860. [CrossRef]

39. Mailloux, R.J. Protein S-glutathionylation reactions as a global inhibitor of cell metabolism for the desensitization of hydrogen peroxide signals. Redox Biol. 2020, 32. [CrossRef]

40. Chardonnet, S.; Sakr, S.; Cassier-Chauvat, C.; Le Maréchal, P.; Chauvat, F.; Lemaire, S.D.; Decottignies, P. First proteomic study of S-glutathionylation in cyanobacteria. J. Proteome Res. 2015, 14, 59-71. [CrossRef]

41. Sakr, S.; Dutheil, J.; Saenkham, P.; Bottin, H.; Leplat, C.; Ortega-Ramos, M.; Aude, J.C.; Chapuis, V.; Guedeney, G.; Decottignies, P.; et al. The activity of the Synechocystis PCC6803 AbrB2 regulator of hydrogen production can be post-translationally controlled through glutathionylation. Int. J. Hydrog. Energy 2013, 38, 13547-13555. [CrossRef]

42. Gallé, Á.; Czékus, Z.; Bela, K.; Horváth, E.; Ördög, A.; Csiszár, J.; Poór, P. Plant glutathione transferases and light. Front. Plant Sci. 2019, 9. [CrossRef] [PubMed]

43. Sylvestre-Gonon, E.; Law, S.R.; Schwartz, M.; Robe, K.; Keech, O.; Didierjean, C.; Dubos, C.; Rouhier, N.; Hecker, A. Functional, structural and biochemical features of plant serinyl-glutathione transferases. Front. Plant Sci. 2019, 10. [CrossRef] [PubMed]

44. Couto, N.; Wood, J.; Barber, J. The role of glutathione reductase and related enzymes on cellular redox homoeostasis network. Free Radic. Biol. Med. 2016, 95, 27-42. [CrossRef] [PubMed]

45. Marteyn, B.; Domain, F.; Legrain, P.; Chauvat, F.; Cassier-Chauvat, C. The thioredoxin reductase-glutaredoxins-ferredoxin crossroad pathway for selenate tolerance in Synechocystis PCC6803. Mol. Microbiol. 2009, 71, 520-532. [CrossRef] [PubMed]

46. Fleischmann, R.D.; Adams, M.D.; White, O.; Clayton, R.A.; Kirkness, E.F.; Kerlavage, A.R.; Bult, C.J.; Tomb, J.F.; Dougherty, B.A.; Merrick, J.M.; et al. Whole-genome random sequencing and assembly of Haemophilus influenzae Rd. Science 1995, 269, 496-512. [CrossRef]

47. Fraser, C.M.; Gocayne, J.D.; White, O.; Adams, M.D.; Clayton, R.A.; Fleischmann, R.D.; Bult, C.J.; Kerlavage, A.R.; Sutton, G.; Kelley, J.M.; et al. The minimal gene complement of Mycoplasma genitalium. Science 1995, 270, 397-403. [CrossRef]

48. Kaneko, T.; Sato, S.; Kotani, H.; Tanaka, A.; Asamizu, E.; Nakamura, Y.; Miyajima, N.; Hirosawa, M.; Sugiura, M.; Sasamoto, S.; et al. Sequence analysis of the genome of the unicellular cyanobacterium Synechocystis sp. strain PCC6803. II. Sequence determination of the entire genome and assignment of potential protein-coding regions. DNA Res. 1996, 3, 109-136. [CrossRef]

49. Cao, H.; Shimura, Y.; Steffen, M.M.; Yang, Z.; Lu, J.; Joel, A.; Jenkins, L.; Kawachi, M.; Yin, Y.; Garcia-Pichel, F. The trait repertoire enabling cyanobacteria to bloom assessed through comparative genomic complexity and metatranscriptomics. MBio 2020,11 . [CrossRef]

50. Fernandez, L.; Peura, S.; Eiler, A.; Linz, A.M.; McMahon, K.D.; Bertilsson, S. Diazotroph Genomes and Their Seasonal Dynamics in a Stratified Humic Bog Lake. Front. Microbiol. 2020, 11. [CrossRef]

51. Grettenberger, C.L.; Sumner, D.Y.; Wall, K.; Brown, C.T.; Eisen, J.A.; Mackey, T.J.; Hawes, I.; Jospin, G.; Jungblut, A.D. A phylogenetically novel cyanobacterium most closely related to Gloeobacter. ISME J. 2020, 14, 2142-2152. [CrossRef]

52. Salazar, V.W.; Tschoeke, D.A.; Swings, J.; Cosenza, C.A.; Mattoso, M.; Thompson, C.C.; Thompson, F.L. A new genomic taxonomy system for the Synechococcus collective. Environ. Microbiol. 2020. [CrossRef] [PubMed]

53. Tripp, H.J.; Bench, S.R.; Turk, K.A.; Foster, R.A.; Desany, B.A.; Niazi, F.; Affourtit, J.P.; Zehr, J.P. Metabolic streamlining in an open-ocean nitrogen-fixing cyanobacterium. Nature 2010, 464, 90-94. [CrossRef] [PubMed]

54. Dagan, T.; Roettger, M.; Stucken, K.; Landan, G.; Koch, R.; Major, P.; Gould, S.B.; Goremykin, V.V.; Rippka, R.; De Marsac, N.T.; et al. Genomes of stigonematalean cyanobacteria (subsection $\mathrm{V}$ ) and the evolution of oxygenic photosynthesis from prokaryotes to plastids. Genome Biol. Evol. 2013, 5, 31-44. [CrossRef] [PubMed]

55. Larsson, J.; Nylander, J.A.A.; Bergman, B. Genome fluctuations in cyanobacteria reflect evolutionary, developmental and adaptive traits. BMC Evol. Biol. 2011, 11. [CrossRef] [PubMed]

56. Cassier-Chauvat, C.; Poncelet, M.; Chauvat, F. Three insertion sequences from the cyanobacterium Synechocystis PCC6803 support the occurrence of horizontal DNA transfer among bacteria. Gene 1997, 195, 257-266. [CrossRef] 
57. Zhaxybayeva, O.; Gogarten, J.P.; Charlebois, R.L.; Doolittle, W.F.; Papke, R.T. Phylogenetic analyses of cyanobacterial genomes: Quantification of horizontal gene transfer events. Genome Res. 2006, 16, 1099-10108. [CrossRef]

58. Cassier-Chauvat, C.; Veaudor, T.; Chauvat, F. Comparative genomics of DNA recombination and repair in cyanobacteria: Biotechnological implications. Front. Microbiol. 2016, 7. [CrossRef] [PubMed]

59. Godde, J.S.; Baichoo, S.; Mungloo-Dilmohamud, Z.; Jaufeerally-Fakim, Y. Comparison of genomic islands in cyanobacteria: Evidence of bacteriophage-mediated horizontal gene transfer from eukaryotes. Microbiol. Res. 2018, 211, 31-46. [CrossRef]

60. Zeidner, G.; Bielawski, J.P.; Shmoish, M.; Scanlan, D.J.; Sabehi, G.; Béjà, O. Potential photosynthesis gene recombination between Prochlorococcus and Synechococcus via viral intermediates. Environ. Microbiol. 2005, 7, 1505-1513. [CrossRef]

61. Scanlan, D.J.; Ostrowski, M.; Mazard, S.; Dufresne, A.; Garczarek, L.; Hess, W.R.; Post, A.F.; Hagemann, M.; Paulsen, I.; Partensky, F. Ecological Genomics of Marine Picocyanobacteria. Microbiol. Mol. Biol. Rev. 2009, 73, 249-299. [CrossRef]

62. Nicholson, M.L.; Gaasenbeek, M.; Laudenbach, D.E. Two enzymes together capable of cysteine biosynthesis are encoded on a cyanobacterial plasmid. MGG Mol. Gen. Genet. 1995, 247, 623-632. [CrossRef] [PubMed]

63. Kimura, A.; Hamada, T.; Morita, E.H.; Hayashi, H. A high temperature-sensitive mutant of Synechococcus sp. PCC 7002 with modifications in the endogenous plasmid, pAQ1. Plant Cell Physiol. 2002, 43, 217-223. [CrossRef] [PubMed]

64. Nagarajan, S.; Sherman, D.M.; Shaw, I.; Sherman, L.A. Functions of the duplicated hik31 operons in central metabolism and responses to light, dark, and carbon sources in Synechocystis sp. strain PCC 6803. J. Bacteriol. 2012, 194, 448-459. [CrossRef] [PubMed]

65. Swingley, W.D.; Chen, M.; Cheung, P.C.; Conrad, A.L.; Dejesa, L.C.; Hao, J.; Honchak, B.M.; Karbach, L.E.; Kurdoglu, A.; Lahiri, S.; et al. Niche adaptation and genome expansion in the chlorophyll d-producing cyanobacterium Acaryochloris marina. Proc. Natl. Acad. Sci. USA 2008, 105, 2005-2010. [CrossRef] [PubMed]

66. Welsh, E.A.; Liberton, M.; Stöckel, J.; Loh, T.; Elvitigala, T.; Wang, C.; Wollam, A.; Fulton, R.S.; Clifton, S.W.; Jacobs, J.M.; et al. The genome of Cyanothece 51142, a unicellular diazotrophic cyanobacterium important in the marine nitrogen cycle. Proc. Natl. Acad. Sci. USA 2008, 105, 15094-15099. [CrossRef]

67. Bandyopadhyay, A.; Elvitigala, T.; Welsh, E.; Stöckel, J.; Liberton, M.; Min, H.; Sherman, L.A.; Pakrasi, H.B. Novel metabolic attributes of the genus Cyanothece, comprising a group of unicellular nitrogen-fixing cyanobacteria. MBio 2011, 2. [CrossRef]

68. Quinn, G.A.; Banat, A.M.; Abdelhameed, A.M.; Banat, I.M. Streptomyces from traditional medicine: Sources of new innovations in antibiotic discovery. J. Med. Microbiol. 2020, 69, 1040-1048. [CrossRef]

69. Ahmed, M.N.; Reyna-González, E.; Schmid, B.; Wiebach, V.; Süssmuth, R.D.; Dittmann, E.; Fewer, D.P. Phylogenomic Analysis of the Microviridin Biosynthetic Pathway Coupled with Targeted Chemo-Enzymatic Synthesis Yields Potent Protease Inhibitors. ACS Chem. Biol. 2017, 12, 1538-1546. [CrossRef]

70. Hoff, G.; Bertrand, C.; Piotrowski, E.; Thibessard, A.; Leblond, P. Genome plasticity is governed by double strand break DNA repair in Streptomyces. Sci. Rep. 2018, 8. [CrossRef]

71. Labella, J.I.; Llop, A.; Contreras, A. The default cyanobacterial linked genome: An interactive platform based on cyanobacterial linkage networks to assist functional genomics. FEBS Lett. 2020, 594, 1661-1674. [CrossRef]

72. Simm, S.; Keller, M.; Selymesi, M.; Schleiff, E. The composition of the global and feature specific cyanobacterial core-genomes. Front. Microbiol. 2015, 6. [CrossRef]

73. Alvarenga, D.O.; Fiore, M.F.; Varani, A.M. A metagenomic approach to cyanobacterial genomics. Front. Microbiol. 2017. [CrossRef]

74. Gonzalez-Esquer, C.R.; Smarda, J.; Rippka, R.; Axen, S.D.; Guglielmi, G.; Gugger, M.; Kerfeld, C.A. Cyanobacterial ultrastructure in light of genomic sequence data. Photosynth. Res. 2016, 192, 147-157. [CrossRef]

75. Shih, P.M.; Wu, D.; Latifi, A.; Axen, S.D.; Fewer, D.P.; Talla, E.; Calteau, A.; Cai, F.; Tandeau de Marsac, N.; Rippka, R.; et al. Improving the coverage of the cyanobacterial phylum using diversity-driven genome sequencing. Proc. Natl. Acad. Sci. USA 2013, 110, 1053-1058. [CrossRef] [PubMed]

76. Harel, A.; Karkar, S.; Cheng, S.; Falkowski, P.G.; Bhattacharya, D. Deciphering primordial cyanobacterial genome functions from protein network analysis. Curr. Biol. 2015, 25, 628-634. [CrossRef] [PubMed]

77. Sánchez-Baracaldo, P.; Cardona, T. On the origin of oxygenic photosynthesis and Cyanobacteria. New Phytol. 2020, 225, 1440-1446. [CrossRef]

78. Ponce-Toledo, R.I.; López-García, P.; Moreira, D. Horizontal and endosymbiotic gene transfer in early plastid evolution. New Phytol. 2019, 224, 618-624. [CrossRef] [PubMed]

79. Kopf, M.; Klähn, S.; Pade, N.; Weingärtner, C.; Hagemann, M.; Voß, B.; Hess, W.R. Comparative genome analysis of the closely related Synechocystis strains PCC 6714 and PCC 6803. DNA Res. 2014, 21, 255-266. [CrossRef]

80. Gale, G.A.R.; Osorio, A.A.S.; Mills, L.A.; Wang, B.; Lea-Smith, D.J.; McCormick, A.J. Emerging species and genome editing tools: Future prospects in cyanobacterial synthetic biology. Microorganisms 2019, 7, 409. [CrossRef]

81. Janasch, M.; Asplund-Samuelsson, J.; Steuer, R.; Hudson, E.P. Kinetic modeling of the Calvin cycle identifies flux control and stable metabolomes in Synechocystis carbon fixation. J. Exp. Bot. 2019, 70, 973-983. [CrossRef]

82. Lasry Testa, R.; Delpino, C.; Estrada, V.; Diaz, S.M. In silico strategies to couple production of bioethanol with growth in cyanobacteria. Biotechnol. Bioeng. 2019, 116, 2061-2073. [CrossRef]

83. Khan, A.Z.; Bilal, M.; Mehmood, S.; Sharma, A.; Iqbal, H.M.N. State-of-the-art genetic modalities to engineer cyanobacteria for sustainable biosynthesis of biofuel and fine-chemicals to meet bio-economy challenges. Life 2019, 9, 54. [CrossRef] [PubMed] 
84. Santos-Merino, M.; Singh, A.K.; Ducat, D.C. New applications of synthetic biology tools for cyanobacterial metabolic engineering. Front. Bioeng. Biotechnol. 2019, 7. [CrossRef] [PubMed]

85. Wu, C.; Jiang, H.; Kalra, I.; Wang, X.; Cano, M.; Maness, P.C.; Yu, J.; Xiong, W. A generalized computational framework to streamline thermodynamics and kinetics analysis of metabolic pathways. Metab. Eng. 2020, 57, 140-150. [CrossRef]

86. Hendry, J.I.; Bandyopadhyay, A.; Srinivasan, S.; Pakrasi, H.B.; Maranas, C.D. Metabolic model guided strain design of cyanobacteria. Curr. Opin. Biotechnol. 2020, 64, 17-23. [CrossRef]

87. Mukherjee, B.; Madhu, S.; Wangikar, P.P. The role of systems biology in developing non-model cyanobacteria as hosts for chemical production. Curr. Opin. Biotechnol. 2020, 64, 62-69. [CrossRef] [PubMed]

88. Bender, R.A. The danger of annotation by analogy: Most "thii" genes play no role in thiamine biosynthesis. J. Bacteriol. 2011, 193, 4574-4575. [CrossRef]

89. Fujisawa, T.; Narikawa, R.; Maeda, S.I.; Watanabe, S.; Kanesaki, Y.; Kobayashi, K.; Nomata, J.; Hanaoka, M.; Watanabe, M.; Ehira, S.; et al. CyanoBase: A large-scale update on its 20th anniversary. Nucleic Acids Res. 2017, 45, D551-D554. [CrossRef]

90. Domain, F.; Houot, L.; Chauvat, F.; Cassier-Chauvat, C. Function and regulation of the cyanobacterial genes lexA, recA and ruvB: LexA is critical to the survival of cells facing inorganic carbon starvation. Mol. Microbiol. 2004, 53, 65-80. [CrossRef]

91. Figge, R.M.; Cassier-Chauvat, C.; Chauvat, F.; Cerff, R. Characterization and analysis of an NAD(P)H dehydrogenase transcriptional regulator critical for the survival of cyanobacteria facing inorganic carbon starvation and osmotic stress. Mol. Microbiol. 2001, 39, 455-468. [CrossRef]

92. Jiang, Y.L.; Wang, X.P.; Sun, H.; Han, S.J.; Li, W.F.; Cui, N.; Lin, G.M.; Zhang, J.Y.; Cheng, W.; Cao, D.D.; et al. Coordinating carbon and nitrogen metabolic signaling through the cyanobacterial global repressor NdhR. Proc. Natl. Acad. Sci. USA 2017, 115, 403-408. [CrossRef]

93. Forchhammer, K.; Selim, K.A. Carbon/nitrogen homeostasis control in cyanobacteria. FEMS Microbiol. Rev. 2019, 44, 33-53. [CrossRef]

94. Cotton, C.A.R.; Kabasakal, B.V.; Miah, N.A.; Murray, J.W. Structure of the dual-function fructose-1,6/sedoheptulose-1,7bisphosphatase from Thermosynechococcus elongatus bound with sedoheptulose-7-phosphate. Acta Crystallogr. Sect. Struct. Biol. Commun. 2015, 71, 1341-1345. [CrossRef]

95. Mohamed, H.E.; Vermaas, W.F.J. S110254 (CrtLdiox) is a bifunctional lycopene cyclase/dioxygenase in cyanobacteria producing myxoxanthophyll. J. Bacteriol. 2006, 188, 3337-3344. [CrossRef]

96. Yeremenko, N.; Kouřil, R.; Ihalainen, J.A.; D’Haene, S.; Van Oosterwijk, N.; Andrizhiyevskaya, E.G.; Keegstra, W.; Dekker, H.L.; Hagemann, M.; Boekema, E.J.; et al. Supramolecular organization and dual function of the IsiA chlorophyll-binding protein in cyanobacteria. Biochemistry 2004, 43, 10308-10313. [CrossRef] [PubMed]

97. Burnat, M.; Picossi, S.; Valladares, A.; Herrero, A.; Flores, E. Catabolic pathway of arginine in Anabaena involves a novel bifunctional enzyme that produces proline from arginine. Mol. Microbiol. 2019, 111, 883-897. [CrossRef] [PubMed]

98. Lee, H.; Rhee, S. Structural and mutational analyses of the bifunctional arginine dihydrolase and ornithine cyclodeaminase AgrE from the cyanobacterium Anabaena. J. Biol. Chem. 2020, 295, 5751-5760. [CrossRef]

99. Phogosee, S.; Hibino, T.; Kageyama, H.; Waditee-Sirisattha, R. Bifunctional alanine dehydrogenase from the halotolerant cyanobacterium Aphanothece halophytica: Characterization and molecular properties. Arch. Microbiol. 2018, 200, 719-727. [CrossRef] [PubMed]

100. Martínez-Noël, G.M.A.; Cumino, A.C.; De Los Angeles Kolman, M.; Salerno, G.L. First evidence of sucrose biosynthesis by single cyanobacterial bimodular proteins. FEBS Lett. 2013, 587, 1669-1674. [CrossRef]

101. Jakopitsch, C.; Regelsberger, G.; Furtmüller, P.G.; Rüker, F.; Peschek, G.A.; Obinger, C. Catalase-peroxidase from Synechocystis is capable of chlorination and bromination reactions. Biochem. Biophys. Res. Commun. 2001, 287, 682-687. [CrossRef]

102. Jakopitsch, C.; Auer, M.; Ivancich, A.; Rüker, F.; Furtmüller, P.G.; Obinger, C. Total conversion of bifunctional catalase-peroxidase (KatG) to monofunctional peroxidase by exchange of a conserved distal side tyrosine. J. Biol. Chem. 2003, 278, 20185-20191. [CrossRef] [PubMed]

103. Zhang, S.; Laborde, S.M.; Frankel, L.K.; Bricker, T.M. Four Novel Genes Required for Optimal Photoautotrophic Growth of the Cyanobacterium Synechocystis sp. Strain PCC 6803 Identified by In Vitro Transposon Mutagenesis. J. Bacteriol. 2004, 186, 875-879. [CrossRef]

104. Terauchi, K.; Sobue, R.; Furutani, Y.; Aoki, R.; Fujita, Y. Isolation of cyanobacterial mutants exhibiting growth defects under microoxic conditions by transposon tagging mutagenesis of Synechocystis sp. PCC 6803. J. Gen. Appl. Microbiol. 2017, 63, 131-138. [CrossRef]

105. Katayama, M.; Tsinoremas, N.F.; Kondo, T.; Golden, S.S. cpmA, a gene involved in an output pathway of the cyanobacterial circadian system. J. Bacteriol. 1999, 181, 3516-3524. [CrossRef] [PubMed]

106. Miyagishima, S.Y.; Wolk, P.P.; Osteryoung, K.W. Identification of cyanobacterial cell division genes by comparative and mutational analyses. Mol. Microbiol. 2005, 56, 126-143. [CrossRef] [PubMed]

107. Watabe, K.; Mimuro, M.; Tsuchiya, T. Development of a high-frequency in vivo transposon mutagenesis system for Synechocystis sp. PCC 6803 and Synechococcus elongatus PCC 7942. Plant Cell Physiol. 2014, 55, 2017-2028. [CrossRef] [PubMed]

108. Rubin, B.E.; Wetmore, K.M.; Price, M.N.; Diamond, S.; Shultzaberger, R.K.; Lowe, L.C.; Curtin, G.; Arkin, A.P.; Deutschbauer, A.; Golden, S.S. The essential gene set of a photosynthetic organism. Proc. Natl. Acad. Sci. USA 2015, 112. [CrossRef] 
109. Ozaki, H.; Ikeuchi, M.; Ogawa, T.; Fukuzawa, H.; Sonoike, K. Large-scale analysis of chlorophyll fluorescence kinetics in Synechocystis sp. PCC 6803: Identification of the factors involved in the modulation of photosystem stoichiometry. Plant Cell Physiol. 2007, 48, 451-458. [CrossRef]

110. Kato, K.; Tanaka, R.; Sano, S.; Tanaka, A.; Hosaka, H. Identification of a gene essential for protoporphyrinogen IX oxidase activity in the cyanobacterium Synechocystis sp. PCC6803. Proc. Natl. Acad. Sci. USA 2010, 107, 16649-16654. [CrossRef]

111. Zhang, S.; Frankel, L.K.; Bricker, T.M. The S1l0606 protein is required for photosystem II assembly/stability in the cyanobacterium Synechocystis sp. PCC 6803. J. Biol. Chem. 2010, 285, 32047-32054. [CrossRef]

112. Shibata, M.; Ohkawa, H.; Kaneko, T.; Fukuzawa, H.; Tabata, S.; Kaplan, A.; Ogawa, T. Distinct constitutive and low-CO ${ }_{2}$-induced $\mathrm{CO}_{2}$ uptake systems in cyanobacteria: Genes involved and their phylogenetic relationship with homologous genes in other organisms. Proc. Natl. Acad. Sci. USA 2001, 98, 11789-11794. [CrossRef]

113. Shibata, M.; Katoh, H.; Sonoda, M.; Ohkawa, H.; Shimoyama, M.; Fukuzawa, H.; Kaplan, A.; Ogawa, T. Genes essential to sodiumdependent bicarbonate transport in cyanobacteria: Function and phylogenetic analysis. J. Biol. Chem. 2002, 277, 18658-18664. [CrossRef]

114. Tyo, K.E.J.; Espinoza, F.A.; Stephanopoulos, G.; Jin, Y.S. Identification of gene disruptions for increased poly-3-hydroxybutyrate accumulation in Synechocystis PCC 6803. Biotechnol. Prog. 2009, 25, 1236-1243. [CrossRef] [PubMed]

115. Battchikova, N.; Wei, L.; Du, L.; Bersanini, L.; Aro, E.M.; Ma, W. Identification of novel Ssl0352 protein (NdhS), essential for efficient operation of cyclic electron transport around photosystem I, in NADPH:plastoquinone oxidoreductase (NDH-1) complexes of Synechocystis sp. PCC 6803. J. Biol. Chem. 2011, 286, 36992-37001. [CrossRef]

116. Dai, H.; Zhang, L.; Zhang, J.; Mi, H.; Ogawa, T.; Ma, W. Identification of a cyanobacterial CRR6 protein, Slr1097, required for efficient assembly of NDH-1 complexes in Synechocystis sp. PCC 6803. Plant J. 2013, 75, 858-866. [CrossRef] [PubMed]

117. Zhang, J.; Gao, F.; Zhao, J.; Ogawa, T.; Wang, Q.; Ma, W.W. NdhP Is an exclusive subunit of large complex of NADPH dehydrogenase essential to stabilize the complex in Synechocystis sp. Strain PCC 6803. J. Biol. Chem. 2014, 289, 26669-26676. [CrossRef]

118. Zhao, J.; Rong, W.; Gao, F.; Ogawa, T.; Ma, W. Subunit Q is required to stabilize the large complex of NADPH dehydrogenase in Synechocystis sp. Strain PCC 6803. Plant Physiol. 2015, 168, 443-451. [CrossRef]

119. Gao, F.; Zhao, J.; Wang, X.; Qin, S.; Wei, L.; Ma, W. NdhV is a subunit of NADPH dehydrogenase essential for cyclic electron transport in Synechocystis sp. strain PCC 6803. Plant Physiol. 2016, 170, 752-760. [CrossRef] [PubMed]

120. He, Z.; Xu, M.; Wu, Y.; Lv, J.; Fu, P.; Mi, H. NdhM subunit is required for the stability and the function of NAD $(\mathrm{P}) \mathrm{H}$ dehydrogenase complexes involved in $\mathrm{CO}_{2}$ uptake in Synechocystis sp. strain PCC 6803. J. Biol. Chem. 2016, 60, 1374-1385. [CrossRef]

121. Wang, X.; Gao, F.; Zhang, J.; Zhao, J.; Ogawa, T.; Ma, W. A cytoplasmic protein Ssl3829 is important for NDH-1 hydrophilic arm assembly in Synechocystis sp. Strain PCC 6803. Plant Physiol. 2016, 171, 864-877. [CrossRef] [PubMed]

122. Voshol, G.P.; Meyer, V.; van den Hondel, C.A.M.J.J. GTP-binding protein Era: A novel gene target for biofuel production. BMC Biotechnol. 2015, 15. [CrossRef]

123. Cassier-Chauvat, C.; Chauvat, F. Function and Regulation of Ferredoxins in the Cyanobacterium, Synechocystis PCC6803: Recent Advances. Life 2014, 4, 666-680. [CrossRef]

124. Lelong, C.; Boekema, E.J.; Kruip, J.; Bottin, H.; Rögner, M.; Sétif, P. Characterization of a redox active cross-linked complex between cyanobacterial photosystem I and soluble ferredoxin. EMBO J. 1996, 15, 2160-2168. [CrossRef]

125. Poncelet, M.; Cassier-Chauvat, C.; Leschelle, X.; Bottin, H.; Chauvat, F. Targeted deletion and mutational analysis of the essential (2Fe-2S) plant-like ferredoxin in Synechocystis PCC6803 by plasmid shuffling. Mol. Microbiol. 1998, 28, 813-821. [CrossRef] [PubMed]

126. Mazouni, K.; Domain, F.; Chauvat, F.; Cassier-Chauvat, C. Expression and regulation of the crucial plant-like ferredoxin of cyanobacteria. Mol. Microbiol. 2003, 49, 1019-1029. [CrossRef] [PubMed]

127. Schorsch, M.; Kramer, M.; Goss, T.; Eisenhut, M.; Robinson, N.; Osman, D.; Wilde, A.; Sadaf, S.; Brückler, H.; Walder, L.; et al. A unique ferredoxin acts as a player in the low-iron response of photosynthetic organisms. Proc. Natl. Acad. Sci. USA 2018, 115, 12111-12120. [CrossRef]

128. Mustila, H.; Allahverdiyeva, Y.; Isojärvi, J.; Aro, E.M.; Eisenhut, M. The bacterial-type [4Fe-4S] ferredoxin 7 has a regulatory function under photooxidative stress conditions in the cyanobacterium Synechocystis sp. PCC 6803. Biochim. Biophys. Acta Bioenerg. 2014, 1837, 1293-1304. [CrossRef] [PubMed]

129. Hanke, G.T.; Satomi, Y.; Shinmura, K.; Takao, T.; Hase, T. A screen for potential ferredoxin electron transfer partners uncovers new, redox dependent interactions. Biochim. Biophys. Acta Proteins Proteom. 2011, 1814, 366-374. [CrossRef]

130. Angeleri, M.; Zorina, A.; Aro, E.M.; Battchikova, N. Interplay of SpkG kinase and the Slr0151 protein in the phosphorylation of ferredoxin 5 in Synechocystis sp. strain PCC 6803. FEBS Lett. 2018, 592, 411-421. [CrossRef]

131. Mondal, S.; Kumar, V.; Singh, S.P. Phylogenetic distribution and structural analyses of cyanobacterial glutaredoxins (Grxs). Comput. Biol. Chem. 2020, 84. [CrossRef]

132. Zaffagnini, M.; Bedhomme, M.; Marchand, C.H.; Morisse, S.; Trost, P.; Lemaire, S.D. Redox regulation in photosynthetic organisms: Focus on glutathionylation. Antioxid. Redox Signal. 2012, 16, 567-586. [CrossRef] [PubMed]

133. Sánchez-Riego, A.M.; López-Maury, L.; Florencio, F.J. Glutaredoxins are essential for stress adaptation in the cyanobacterium Synechocystis sp. PCC 6803. Front. Plant Sci. 2013. [CrossRef] [PubMed] 
134. López-Maury, L.; Sánchez-Riego, A.M.; Reyes, J.C.; Florencio, F.J. The glutathione/glutaredoxin system is essential for arsenate reduction in Synechocystis sp. strain PCC 6803. J. Bacteriol. 2009, 191, 3534-3543. [CrossRef] [PubMed]

135. Kim, S.G.; Chung, J.S.; Sutton, R.B.; Lee, J.S.; López-Maury, L.; Lee, S.Y.; Florencio, F.J.; Lin, T.; Zabet-Moghaddam, M.; Wood, M.J.; et al. Redox, mutagenic and structural studies of the glutaredoxin/arsenate reductase couple from the cyanobacterium Synechocystis sp. PCC 6803. Biochim. Biophys. Acta Proteins Proteom. 2012, 1824, 392-403. [CrossRef] [PubMed]

136. Iwema, T.; Picciocchi, A.; Traore, D.A.K.; Ferrer, J.L.; Chauvat, F.; Jacquamet, L. Structural basis for delivery of the intact [Fe2S2] cluster by monothiol glutaredoxin. Biochemistry 2009, 48, 6041-6043. [CrossRef] [PubMed]

137. Deponte, M. Glutathione catalysis and the reaction mechanisms of glutathione-dependent enzymes. Biochim. Biophys. Acta Gen. Subj. 2013, 1830, 3217-3266. [CrossRef]

138. Nianiou-Obeidat, I.; Madesis, P.; Kissoudis, C.; Voulgari, G.; Chronopoulou, E.; Tsaftaris, A.; Labrou, N.E. Plant glutathione transferase-mediated stress tolerance: Functions and biotechnological applications. Plant Cell Rep. 2017, 36, 791-805. [CrossRef]

139. Oakley, A. Glutathione transferases: A structural perspective. Drug Metab. Rev. 2011, 43, 138-151. [CrossRef]

140. Wiktelius, E.; Stenberg, G. Novel class of glutathione transferases from cyanobacteria exhibit high catalytic activities towards naturally occurring isothiocyanates. Biochem. J. 2007, 406, 115-123. [CrossRef]

141. Naciyar, M.S.; Karthick, L.; Prakasam, P.A.; Deviram, G.; Uma, L.; Prabaharan, D.; Saha, S.K. Diversity of glutathione S-transferases (GSTs) in cyanobacteria with reference to their structures, substrate recognition and catalytic functions. Microorganisms 2020, 8, 712. [CrossRef]

142. Pandey, T.; Chhetri, G.; Chinta, R.; Kumar, B.; Singh, D.B.; Tripathi, T.; Singh, A.K. Functional classification and biochemical characterization of a novel rho class glutathione S-transferase in Synechocystis PCC 6803. FEBS Open Bio 2015, 5, 1-7. [CrossRef] [PubMed]

143. Pandey, T.; Singh, S.K.; Chhetri, G.; Tripathi, T.; Singh, A.K. Characterization of a highly pH stable Chi-class glutathione S-transferase from Synechocystis PCC 6803. PLoS ONE 2015, 10, e0126811. [CrossRef] [PubMed]

144. Pandey, T.; Shukla, R.; Shukla, H.; Sonkar, A.; Tripathi, T.; Singh, A.K. A combined biochemical and computational studies of the rho-class glutathione s-transferase sll1545 of Synechocystis PCC 6803. Int. J. Biol. Macromol. 2017, 94, 378-385. [CrossRef]

145. Kammerscheit, X.; Hecker, A.; Rouhier, N.; Chauvat, F.; Cassier-Chauvat, C. Methylglyoxal Detoxification Revisited: Role of Glutathione Transferase in Model Cyanobacterium Synechocystis sp. Strain PCC 6803. MBio 2020, 11. [CrossRef] [PubMed]

146. Stanier, R.Y.; Kunisawa, R.; Mandel, M.; Cohen-Bazire, G. Purification and properties of unicellular blue-green algae (order Chroococcales). Bacteriol. Rev. 1971, 35, 171-205. [CrossRef] [PubMed]

147. Rippka, R.; Deruelles, J.; Waterbury, J.B.; Herdman, M.; Stanier, R.Y. Generic assignments, strain histories and properties of pure cultures of cyano- bacteria. Journal of General Microbiology 11: 1-61. J. Gen. Microbiol. 1979, 111, 1-61. [CrossRef]

148. Niu, T.C.; Lin, G.M.; Xie, L.R.; Wang, Z.Q.; Xing, W.Y.; Zhang, J.Y.; Zhang, C.C. Expanding the Potential of CRISPR-Cpf1-Based Genome Editing Technology in the Cyanobacterium Anabaena PCC 7120. ACS Synth. Biol. 2019, 8, 170-180. [CrossRef]

149. Yu, J.; Liberton, M.; Cliften, P.F.; Head, R.D.; Jacobs, J.M.; Smith, R.D.; Koppenaal, D.W.; Brand, J.J.; Pakrasi, H.B. Synechococcus elongatus UTEX 2973, a fast growing cyanobacterial chassis for biosynthesis using light and $\mathrm{CO}_{2}$. Sci. Rep. 2015, 5. [CrossRef]

150. Jaiswal, D.; Sengupta, A.; Sohoni, S.; Sengupta, S.; Phadnavis, A.G.; Pakrasi, H.B.; Wangikar, P.P. Genome Features and Biochemical Characteristics of a Robust, Fast Growing and Naturally Transformable Cyanobacterium Synechococcus elongatus PCC 11801 Isolated from India. Sci. Rep. 2018, 8. [CrossRef]

151. Jaiswal, D.; Sengupta, A.; Sengupta, S.; Madhu, S.; Pakrasi, H.B.; Wangikar, P.P. A Novel Cyanobacterium Synechococcus elongatus PCC 11802 has Distinct Genomic and Metabolomic Characteristics Compared to its Neighbor PCC 11801. Sci. Rep. 2020, 10. [CrossRef]

152. Włodarczyk, A.; Selão, T.T.; Norling, B.; Nixon, P.J. Newly discovered Synechococcus sp. PCC 11901 is a robust cyanobacterial strain for high biomass production. Commun. Biol. 2020, 3. [CrossRef] [PubMed]

153. Tan, X.; Hou, S.; Song, K.; Georg, J.; Klähn, S.; Lu, X.; Hess, W.R. The primary transcriptome of the fast-growing cyanobacterium Synechococcus elongatus UTEX 2973. Biotechnol. Biofuels 2018, 11. [CrossRef] [PubMed]

154. Lou, W.; Tan, X.; Song, K.; Zhang, S.; Luan, G.; Li, C.; Lu, X. A specific single nucleotide polymorphism in the ATP synthase gene significantly improves environmental stress tolerance of Synechococcus elongatus PCC 7942. Appl. Environ. Microbiol. 2018, 84. [CrossRef] [PubMed]

155. Bachin, D.; Nazarenko, L.V.; Mironov, K.S.; Pisareva, T.; Allakhverdiev, S.I.; Los, D.A. Mechanosensitive ion channel MscL controls ionic fluxes during cold and heat stress in Synechocystis. FEMS Microbiol. Lett. 2015, 362. [CrossRef] [PubMed]

156. Li, S.; Sun, T.; Xu, C.; Chen, L.; Zhang, W. Development and optimization of genetic toolboxes for a fast-growing cyanobacterium Synechococcus elongatus UTEX 2973. Metab. Eng. 2018, 48, 163-174. [CrossRef]

157. Ungerer, J.; Wendt, K.E.; Hendry, J.I.; Maranas, C.D.; Pakrasi, H.B. Comparative genomics reveals the molecular determinants of rapid growth of the cyanobacterium Synechococcus elongatus UTEX 2973. Proc. Natl. Acad. Sci. USA 2018, 115. [CrossRef] [PubMed]

158. Zhang, M.; Qiao, C.; Luan, G.; Luo, Q.; Lu, X. Systematic Identification of Target Genes for Cellular Morphology Engineering in Synechococcus elongatus PCC7942. Front. Microbiol. 2020, 11. [CrossRef]

159. Golden, S.S. Principles of rhythmicity emerging from cyanobacteria. Eur. J. Neurosci. 2020, 51, 13-18. [CrossRef]

160. MacCready, J.S.; Basalla, J.L.; Vecchiarelli, A.G. Origin and Evolution of Carboxysome Positioning Systems in Cyanobacteria. Mol. Biol. Evol. 2020. [CrossRef] 
161. Labarre, J.; Chauvat, F.; Thuriaux, P. Insertional mutagenesis by random cloning of antibiotic resistance genes into the genome of the cyanobacterium Synechocystis strain PCC 6803. J. Bacteriol. 1989, 171, 3449-3457. [CrossRef]

162. Zerulla, K.; Ludt, K.; Soppa, J. The ploidy level of Synechocystis sp. PCC 6803 is highly variable and is influenced by growth phase and by chemical and physical external parameters. Microbiology (UK) 2016, 162, 730-739. [CrossRef] [PubMed]

163. Chauvat, F.; De Vries, L.; Van der Ende, A.; Van Arkel, G.A. A host-vector system for gene cloning in the cyanobacterium Synechocystis PCC 6803. MGG Mol. Gen. Genet. 1986, 204, 185-191. [CrossRef]

164. Yang, X.; McFadden, B.A. A small plasmid, pCA2.4, from the cyanobacterium Synechocystis sp. strain PCC 6803 encodes a Rep protein and replicates by a rolling circle mechanism. J. Bacteriol. 1993, 175, 3981-3991. [CrossRef]

165. Yang, X.; McFadden, B.A. The complete DNA sequence and replication analysis of the plasmid pCB2.4 from the cyanobacterium Synechocystis PCC 6803. Plasmid 1994, 31, 131-137. [CrossRef] [PubMed]

166. Xu, W.; McFadden, B.A. Sequence analysis of plasmid pCC5.2 from cyanobacterium Synechocystis PCC 6803 that replicates by a rolling circle mechanism. Plasmid 1997, 37, 95-104. [CrossRef] [PubMed]

167. Kaneko, T.; Nakamura, Y.; Sasamoto, S.; Watanabe, A.; Kohara, M.; Matsumoto, M.; Shimpo, S.; Yamada, M.; Tabata, S. Structural analysis of four large plasmids harboring in a unicellular cyanobacterium, Synechocystis sp. PCC 6803. DNA Res. 2003, 10, 221-228. [CrossRef]

168. Berla, B.M.; Pakrasi, H.B. Upregulation of plasmid genes during stationary phase in Synechocystis sp. strain PCC 6803, a cyanobacterium. Appl. Environ. Microbiol. 2012, 18. [CrossRef]

169. Castets, A.M.; Houmard, J.; Tandeau de Marsac, N. Is cell motility a plasmid-encoded function in the cyanobacterium Synechocystis 6803? FEMS Microbiol. Lett. 1986, 37, 277-281. [CrossRef]

170. Kopfmann, S.; Hess, W.R. Toxin-antitoxin systems on the large defense plasmid pSYSA of Synechocystis sp. pCC 6803. J. Biol. Chem. 2013, 288, 7399-7409. [CrossRef]

171. Kopfmann, S.; Roesch, S.K.; Hess, W.R. Type II toxin-antitoxin systems in the unicellular cyanobacterium Synechocystis sp. PCC 6803. Toxins 2016, 8, 228. [CrossRef]

172. Paynter, J.J.; Andres-Enguix, I.; Fowler, P.W.; Tottey, S.; Cheng, W.; Enkvetchakul, D.; Bavro, V.N.; Kusakabe, Y.; Sansom, M.S.P.; Robinson, N.J.; et al. Functional complementation and genetic deletion studies of KirBac channels: Activatory mutations highlight gating-sensitive domains. J. Biol. Chem. 2010, 285, 40754-40761. [CrossRef] [PubMed]

173. Giner-Lamia, J.; López-Maury, L.; Reyes, J.C.; Florencio, F.J. The CopRS two-component system is responsible for resistance to copper in the cyanobacterium Synechocystis sp. PCC 6803. Plant Physiol. 2012, 159, 1806-1818. [CrossRef] [PubMed]

174. De Alvarenga, L.V.; Hess, W.R.; Hagemann, M. AcnSP-A Novel Small Protein Regulator of Aconitase Activity in the Cyanobacterium Synechocystis sp. PCC 6803. Front. Microbiol. 2020, 11. [CrossRef] [PubMed]

175. Bird, A.J.; Turner-Cavet, J.S.; Lakey, J.H.; Robinson, N.J. A carboxyl-terminal Cys2/His2-type zinc-finger motif in DNA primase influences DNA content in Synechococcus PCC 7942. J. Biol. Chem. 1998, 273, 21246-21252. [CrossRef]

176. Griese, M.; Lange, C.; Soppa, J. Ploidy in cyanobacteria. FEMS Microbiol. Lett. 2011, 323, 124-131. [CrossRef]

177. Watanabe, S.; Ohbayashi, R.; Kanesaki, Y.; Saito, N.; Chibazakura, T.; Soga, T.; Yoshikawa, H. Intensive DNA replication and metabolism during the lag phase in Cyanobacteria. PLoS ONE 2015, 10, e0136800. [CrossRef]

178. Van Den Hondel, C.A.M.J.J.; Verbeek, S.; van Der Ende, A.; Weisbeek, P.J.; Borrias, W.E.; van Arkel, G.A. Introduction of transposon Tn901 into a plasmid of Anacystis nidulans: Preparation for cloning in cyanobacteria. Proc. Natl. Acad. Sci. USA 1980, 77, 1570-1574. [CrossRef] [PubMed]

179. Chen, Y.; Kay Holtman, C.; Magnuson, R.D.; Youderian, P.A.; Golden, S.S. The complete sequence and functional analysis of pANL, the large plasmid of the unicellular freshwater cyanobacterium Synechococcus elongatus PCC 7942. Plasmid 2008, 59, 176-192. [CrossRef]

180. Roberts, T.M.; Koths, K.E. The blue-green alga Agmenellum quadruplicatum contains covalently closed DNA circles. Cell 1976, 9 , 551-557. [CrossRef]

181. Akiyama, H.; Kanai, S.; Hirano, M.; Miyasaka, H. Nucleotide sequence of plasmid pAQ1 of marine cyanobacterium Synechococcus sp. PCC7002. DNA Res. 1998, 5, 127-129. [CrossRef]

182. Kuhlemeier, C.J.; Borrias, W.E.; van den Hondel, C.A.M.J.J.; van Arkel, G.A. Vectors for cloning in cyanobacteria: Construction and characterization of two recombinant plasmids capable of transformation to Escherichia coli K12 and Anacystis nidulans R2. MGG Mol. Gen. Genet. 1981, 184, 249-254. [CrossRef]

183. Chauvat, F.; Astier, C.; Vedel, F.; Joset-Espardellier, F. Transformation in the cyanobacterium Synechococcus R2: Improvement of efficiency; Role of the pUH24 plasmid. MGG Mol. Gen. Genet. 1983, 191, 39-45. [CrossRef] [PubMed]

184. Kaneko, T.; Nakamura, Y.; Wolk, C.P.; Kuritz, T.; Sasamoto, S.; Watanabe, A.; Iriguchi, M.; Ishikawa, A.; Kawashima, K.; Kimura, T.; et al. Complete genomic sequence of the filamentous nitrogen-fixing cyanobacterium Anabaena sp. strain PCC 7120. DNA Res. 2001, 8, 205-213. [CrossRef]

185. Ludwig, M.; Bryant, D.A. Acclimation of the global transcriptome of the cyanobacterium Synechococcus sp. strain PCC 7002 to nutrient limitations and different nitrogen sources. Front. Microbiol. 2012, 11. [CrossRef]

186. Labarre, J.; Thuriaux, P.; Chauvat, F. Genetic analysis of amino acid transport in the facultatively heterotrophic cyanobacterium Synechocystis sp. strain 6803. J. Bacteriol. 1987, 169, 4668-4673. [CrossRef] [PubMed]

187. Pérez, A.A.; Liu, Z.; Rodionov, D.A.; Li, Z.; Bryant, D.A. Complementation of cobalamin auxotrophy in Synechococcus sp. strain PCC 7002 and validation of a putative cobalamin riboswitch in vivo. J. Bacteriol. 2016, 198, 2743-2752. [CrossRef] [PubMed] 
188. Sakamoto, T.; Delgaizo, V.B.; Bryant, D.A. Growth on urea can trigger death and peroxidation of the cyanobacterium Synechococcus sp. strain PCC 7002. Appl. Environ. Microbiol. 1998, 64, 2361-2366. [CrossRef]

189. Valladares, A.; Montesinos, M.L.; Herrero, A.; Flores, E. An ABC-type, high-affinity urea permease identified in cyanobacteria. Mol. Microbiol. 2002, 43, 703-715. [CrossRef]

190. Veaudor, T.; Cassier-Chauvat, C.; Chauvat, F. Genomics of Urea Transport and Catabolism in Cyanobacteria: Biotechnological Implications. Front. Microbiol. 2019, 10. [CrossRef]

191. Kirsch, F.; Klähn, S.; Hagemann, M. Salt-Regulated Accumulation of the Compatible Solutes Sucrose and Glucosylglycerol in Cyanobacteria and Its Biotechnological Potential. Front. Microbiol. 2019, 10. [CrossRef]

192. Årstøl, E.; Hohmann-Marriott, M.F. Cyanobacterial siderophores—physiology, structure, biosynthesis, and applications. Mar. Drugs 2019, 17, 281. [CrossRef] [PubMed]

193. Onizuka, T.; Endo, S.; Akiyama, H.; Kanai, S.; Hirano, M.; Yokota, A.; Tanaka, S.; Miyasaka, H. The rbcX gene product promotes the production and assembly of ribulose-1,5-bisphosphate carboxylase/oxygenase of Synechococcus sp. PCC7002 in Escherichia coli. Plant Cell Physiol. 2004, 45, 1390-1395. [CrossRef]

194. Emlyn-Jones, D.; Woodger, F.J.; Price, G.D.; Whitney, S.M. RbcX can function as a Rubisco chaperonin, but is non-essential in Synechococcus PCC7942. Plant Cell Physiol. 2006, 47, 1630-1640. [CrossRef] [PubMed]

195. Bracher, A.; Whitney, S.M.; Hartl, F.U.; Hayer-Hartl, M. Biogenesis and Metabolic Maintenance of Rubisco. Annu. Rev. Plant Biol. 2017, 68, 29-60. [CrossRef]

196. Helman, Y.; Tchernov, D.; Reinhold, L.; Shibata, M.; Ogawa, T.; Schwarz, R.; Ohad, I.; Kaplan, A. Genes encoding A-type flavoproteins are essential for photoreduction of $\mathrm{O}_{2}$ in cyanobacteria. Curr. Biol. 2003, 13, 230-235. [CrossRef]

197. Vicente, J.B.; Gomes, C.M.; Wasserfallen, A.; Teixeira, M. Module fusion in an A-type flavoprotein from the cyanobacterium Synechocystis condenses a multiple-component pathway in a single polypeptide chain. Biochem. Biophys. Res. Commun. 2002, 294, 82-87. [CrossRef]

198. Allahverdiyeva, Y.; Mustila, H.; Ermakova, M.; Bersanini, L.; Richaud, P.; Ajlani, G.; Battchikova, N.; Cournac, L.; Aro, E.M. Flavodiiron proteins Flv1 and Flv3 enable cyanobacterial growth and photosynthesis under fluctuating light. Proc. Natl. Acad. Sci. USA 2013, 110, 4111-4116. [CrossRef]

199. Zhang, P.; Allahverdiyeva, Y.; Eisenhut, M.; Aro, E.M. Flavodiiron proteins in oxygenic photosynthetic organisms: Photoprotection of photosystem II by FIv2 and FIv4 in Synechocystis sp. PCC 6803. PLoS ONE 2009, 4, e5331. [CrossRef] [PubMed]

200. Shimakawa, G.; Shaku, K.; Nishi, A.; Hayashi, R.; Yamamoto, H.; Sakamoto, K.; Makino, A.; Miyake, C. FLAVODIIRON2 and FLAVODIIRON4 proteins mediate an oxygen-dependent alternative electron flow in Synechocystis sp. pcc 6803 under $\mathrm{CO}_{2}$-limited conditions. Plant Physiol. 2015, 167, 472-480. [CrossRef]

201. Fujisawa, T.; Okamoto, S.; Katayama, T.; Nakao, M.; Yoshimura, H.; Kajiya-Kanegae, H.; Yamamoto, S.; Yano, C.; Yanaka, Y.; Maita, H.; et al. CyanoBase and RhizoBase: Databases of manually curated annotations for cyanobacterial and rhizobial genomes. Nucleic Acids Res. 2014, 42. [CrossRef]

202. Jittawuttipoka, T.; Planchon, M.; Spalla, O.; Benzerara, K.; Guyot, F.; Cassier-Chauvat, C.; Chauvat, F. Multidisciplinary Evidences that Synechocystis PCC6803 Exopolysaccharides Operate in Cell Sedimentation and Protection against Salt and Metal Stresses. PLoS ONE 2013, 8, e55564. [CrossRef]

203. Planchon, M.; Jittawuttipoka, T.; Cassier-Chauvat, C.; Guyot, F.; Gelabert, A.; Benedetti, M.F.; Chauvat, F.; Spalla, O. Exopolysaccharides protect Synechocystis against the deleterious effects of Titanium dioxide nanoparticles in natural and artificial waters. J. Colloid Interface Sci. 2013, 405, 35-43. [CrossRef] [PubMed]

204. Naveed, S.; Yu, Q.; Zhang, C.; Ge, Y. Extracellular polymeric substances alter cell surface properties, toxicity, and accumulation of arsenic in Synechocystis PCC6803. Environ. Pollut. 2020, 261. [CrossRef] [PubMed]

205. Yu, R.; Chai, H.; Yu, Z.; Wu, X.; Liu, Y.; Shen, L.; Li, J.; Ye, J.; Liu, D.; Ma, T.; et al. Behavior and mechanism of cesium biosorption from aqueous solution by living Synechococcus PCC7002. Microorganisms 2020, 8, 491. [CrossRef] [PubMed]

206. Schatz, D.; Nagar, E.; Sendersky, E.; Parnasa, R.; Zilberman, S.; Carmeli, S.; Mastai, Y.; Shimoni, E.; Klein, E.; Yeger, O.; et al. Self-suppression of biofilm formation in the cyanobacterium Synechococcus elongatus. Environ. Microbiol. 2013, 15, 1786-1794. [CrossRef]

207. Muzzopappa, F.; Kirilovsky, D. Changing Color for Photoprotection: The Orange Carotenoid Protein. Trends Plant Sci. 2020, 25, 92-104. [CrossRef]

208. Kämäräinen, J.; Knoop, H.; Stanford, N.J.; Guerrero, F.; Akhtar, M.K.; Aro, E.M.; Steuer, R.; Jones, P.R. Physiological tolerance and stoichiometric potential of cyanobacteria for hydrocarbon fuel production. J. Biotechnol. 2012, 162, 67-74. [CrossRef]

209. Gupta, A.; Bhagwat, S.G.; Sainis, J.K. Synechococcus elongatus PCC 7942 is more tolerant to chromate as compared to Synechocystis sp. PCC 6803. BioMetals 2013, 26, 309-319. [CrossRef] [PubMed]

210. Gupta, A.; Ballal, A. Unraveling the mechanism responsible for the contrasting tolerance of Synechocystis and Synechococcus to Cr(VI): Enzymatic and non-enzymatic antioxidants. Aquat. Toxicol. 2015, 164, 118-125. [CrossRef] [PubMed]

211. Kämäräinen, J.; Nylund, M.; Aro, E.M.; Kallio, P. Comparison of ethanol tolerance between potential cyanobacterial production hosts. J. Biotechnol. 2018, 283, 140-145. [CrossRef]

212. Ikeuchi, M.; Tabata, S. Synechocystis sp. PCC 6803-A useful tool in the study of the genetics of cyanobacteria. Photosynth. Res. 2001, 70, 73-83. [CrossRef] [PubMed] 
213. Tajima, N.; Sato, S.; Maruyama, F.; Kaneko, T.; Sasaki, N.V.; Kurokawa, K.; Ohta, H.; Kanesaki, Y.; Yoshikawa, H.; Tabata, S.; et al. Genomic structure of the cyanobacterium Synechocystis sp. PCC 6803 strain GT-S. DNA Res. 2011, 18, 393-399. [CrossRef]

214. Morris, J.N.; Crawford, T.S.; Jeffs, A.; Stockwell, P.A.; Eaton-Rye, J.J.; Summerfield, T.C. Whole genome re-sequencing of two "wild-type" strains of the model cyanobacterium Synechocystis sp. PCC 6803. N. Z. J. Bot. 2014, 52, 36-47. [CrossRef]

215. Trautmann, D.; Voß, B.; Wilde, A.; Al-Babili, S.; Hess, W.R. Microevolution in cyanobacteria: Re-sequencing a motile substrain of Synechocystis sp. PCC 6803. DNA Res. 2012, 19, 435-448. [CrossRef]

216. Kanesaki, Y.; Shiwa, Y.; Tajima, N.; Suzuki, M.; Watanabe, S.; Sato, N.; Ikeuchi, M.; Yoshikawa, H. Identification of substrainspecific mutations by massively parallel whole-genome resequencing of Synechocystis sp. PCC 6803. DNA Res. 2012, 19, 67-79. [CrossRef] [PubMed]

217. Tichý, M.; Bečková, M.; Kopečná, J.; Noda, J.; Sobotka, R.; Komenda, J. Strain of Synechocystis PCC 6803 with aberrant assembly of photosystem II contains tandem duplication of a large chromosomal region. Front. Plant Sci. 2016, 7. [CrossRef]

218. Ding, Q.; Chen, G.; Wang, Y.; Wei, D. Identification of specific variations in a non-motile strain of cyanobacterium Synechocystis sp. PCC 6803 originated from ATCC 27184 by whole genome resequencing. Int. J. Mol. Sci. 2015, 16, 24081-24093. [CrossRef]

219. Morris, J.N.; Eaton-Rye, J.J.; Summerfield, T.C. Phenotypic variation in wild-type substrains of the model cyanobacterium Synechocystis sp. PCC 6803. N Z. J. Bot. 2017, 25-35. [CrossRef]

220. Williams, J.G.K. Construction of Specific Mutations in Photosystem II Photosynthetic Reaction Center by Genetic Engineering Methods in Synechocystis 6803. Methods Enzymol. 1988, 167, 766-778. [CrossRef]

221. Zavřel, T.; Očenášová, P.; Červený, J. Phenotypic characterization of Synechocystis sp. PCC 6803 substrains reveals differences in sensitivity to abiotic stress. PLoS ONE 2017, 12, e0189130. [CrossRef]

222. Shestakov, S.V.; Khyen, N.T. Evidence for genetic transformation in blue-green alga Anacystis nidulans. MGG Mol. Gen. Genet. 1970, 107. [CrossRef] [PubMed]

223. Stevens, S.E.; Porter, R.D. Transformation in Agmenellum quadruplicatum. Proc. Natl. Acad. Sci. USA 1980, 77, 6052-6056. [CrossRef]

224. Lambert, D.H.; Stevens, S.E. Photoheterotrophic growth of Agmenellum quadruplicatum PR-6. J. Bacteriol. 1986, 165. [CrossRef] [PubMed]

225. Grigorieva, G.; Shestakov, S. Transformation in the cyanobacterium Synechocystis sp. 6803. FEMS Microbiol. Lett. 1982, 13, 367-370. [CrossRef]

226. Orkwiszewski, K.G.; Kaney, A.R. Genetic transformation of the blue-green bacterium, Anacystis nidulans. Arch. Microbiol. 1974, 98, 31-37. [CrossRef] [PubMed]

227. Kufryk, G.I.; Sachet, M.; Schmetterer, G.; Vermaas, W.F.J. Transformation of the cyanobacterium Synechocystis sp. PCC 6803 as a tool for genetic mapping: Optimization of efficiency. FEMS Microbiol. Lett. 2002, 206, 215-219. [CrossRef] [PubMed]

228. Wendt, K.E.; Pakrasi, H.B. Genomics approaches to deciphering natural transformation in cyanobacteria. Front. Microbiol. 2019, 10. [CrossRef] [PubMed]

229. Taton, A.; Erikson, C.; Yang, Y.; Rubin, B.E.; Rifkin, S.A.; Golden, J.W.; Golden, S.S. The circadian clock and darkness control natural competence in cyanobacteria. Nat. Commun. 2020, 11. [CrossRef]

230. Essich, E.; Stevens, E.; Porter, R.D. Chromosomal transformation in the cyanobacterium Agmenellum quadruplicatum. J. Bacteriol. 1990, 172, 1916-1922. [CrossRef]

231. Williams, J.G.K.; Szalay, A.A. Stable integration of foreign DNA into the chromosome of the cyanobacterium Synechococcus R2. Gene 1983, 24, 37-51. [CrossRef]

232. Buzby, J.S.; Porter, R.D.; Stevens, S.E. Expression of the Escherichia coli lacZ gene on a plasmid vector in a cyanobacterium. Science 1985, 230, 805-807. [CrossRef] [PubMed]

233. Debus, R.J.; Barry, B.A.; Babcock, G.T.; McIntosh, L. Site-directed mutagenesis identifies a tyrosine radical involved in the photosynthetic oxygen-evolving system. Proc. Natl. Acad. Sci. USA 1988, 85. [CrossRef]

234. De Vos, W.M.; Venema, G.; Canosi, U.; Trautner, T.A. Plasmid transformation in Bacillus subtilis: Fate of plasmid DNA. MGG Mol. Gen. Genet. 1981, 181, 424-433. [CrossRef] [PubMed]

235. Jansson, C.; Debus, R.J.; Osiewacz, H.D.; Gurevitz, M.; McIntosh, L. Construction of an Obligate Photoheterotrophic Mutant of the Cyanobacterium Synechocystis 6803. Plant Physiol. 1987, 85, 1021-1025. [CrossRef]

236. Pakrasi, H.B.; Williams, J.G.; Arntzen, C.J. Targeted mutagenesis of the psbE and psbF genes blocks photosynthetic electron transport: Evidence for a functional role of cytochrome b559 in photosystem II. EMBO J. 1988, 7, 325-332. [CrossRef] [PubMed]

237. Vermaas, W.F.J.; Ikeuchi, M.; Inoue, Y. Protein composition of the photosystem II core complex in genetically engineered mutants of the cyanobacterium Synechocystis sp. PCC 6803. Photosynth. Res. 1988, 17, 97-113. [CrossRef]

238. Chitnis, P.R.; Reilly, P.A.; Miedel, M.C.; Nelson, N. Structure and targeted mutagenesis of the gene encoding 8-kDa subunit of photosystem I from the cyanobacterium Synechocystis sp. PCC 6803. J. Biol. Chem. 1989, 264, 18374-18380. [CrossRef]

239. Chauvat, F.; Rouet, P.; Bottin, H.; Boussac, A. Mutagenesis by random cloning of an Escherichia coli kanamycin resistance gene into the genome of the cyanobacterium Synechocystis PCC 6803: Selection of mutants defective in photosynthesis. MGG Mol. Gen. Genet. 1989, 216, 51-59. [CrossRef]

240. Muller, E.G.; Buchanan, B.B. Thioredoxin is essential for photosynthetic growth. The thioredoxin m gene of Anacystis nidulans. J. Biol. Chem. 1989, 264, 4008-4014. [CrossRef]

241. Golden, S.S.; Brusslan, J.; Haselkorn, R. Expression of a family of psbA genes encoding a photosystem II polypeptide in the cyanobacterium Anacystis nidulans R2. EMBO J. 1986, 5, 2789-2798. [CrossRef] [PubMed] 
242. Golden, S.S.; Cho, D.S.; Nalty, M.S. Two functional psbD genes in the cyanobacterium Synechococcus sp. strain PCC 7942. J. Bacteriol. 1989, 171, 4707-4713. [CrossRef]

243. Omata, T.; Carlson, T.J.; Ogawa, T.; Pierce, J. Sequencing and modification of the gene encoding the 42-kilodalton protein in the cytoplasmic membrane of Synechococcus PCC 7942. Plant Physiol. 1990, 93, 305-312. [CrossRef]

244. Laudenbach, D.E.; Herbert, S.K.; McDowell, C.; Fork, D.C.; Grossman, A.R.; Straus, N.A. Cytochrome c-553 is not required for photosynthetic activity in the cyanobacterium Synechococcus. Plant Cell 1990, 2, 913-924. [CrossRef]

245. Bustos, S.A.; Golden, S.S. Light-regulated expression of the psbD gene family in Synecbococcus sp. strain PCC 7942: Evidence for the role of duplicated psbD genes in cyanobacteria. MGG Mol. Gen. Genet. 1992. [CrossRef]

246. Swanson, R.V.; Zhou, J.; Leary, J.A.; Williams, T.; De Lorimier, R.; Bryant, D.A.; Glazer, A.N. Characterization of phycocyanin produced by сpсE and cpcF mutants and identification of an intergenic suppressor of the defect in bilin attachment. J. Biol. Chem. 1992, 267, 16146-16154. [CrossRef]

247. Zhou, J.; Gasparich, G.E.; Stirewalt, V.L.; De Lorimier, R.; Bryant, D.A. The cpcE and cpcF genes of Synechococcus sp. PCC 7002. Construction and phenotypic characterization of interposon mutants. J. Biol. Chem. 1992, 267, 16138-16145. [CrossRef]

248. Schirmacher, A.M.; Hanamghar, S.S. Function and Benefits of Natural Competence in Cyanobacteria: From Ecology to Targeted Manipulation. Life 2020, 10, 249. [CrossRef] [PubMed]

249. Armshaw, P.; Carey, D.; Sheahan, C.; Pembroke, J.T. Utilising the native plasmid, pCA2.4, from the cyanobacterium Synechocystis sp. strain PCC6803 as a cloning site for enhanced product production. Biotechnol. Biofuels 2015, 8. [CrossRef] [PubMed]

250. Kopf, M.; Hess, W.R. Regulatory RNAs in photosynthetic cyanobacteria. FEMS Microbiol. Rev. 2015, 39, 301-315. [CrossRef] [PubMed]

251. Ng, A.H.; Berla, B.M.; Pakrasi, H.B. Fine-tuning of photoautotrophic protein production by combining promoters and neutral sites in the cyanobacterium Synechocystis sp. strain PCC 6803. Appl. Environ. Microbiol. 2015, 81, 6857-6863. [CrossRef] [PubMed]

252. Pinto, F.; Pacheco, C.C.; Oliveira, P.; Montagud, A.; Landels, A.; Couto, N.; Wright, P.C.; Urchueguía, J.F.; Tamagnini, P. Improving a Synechocystis-based photoautotrophic chassis through systematic genome mapping and validation of neutral sites. DNA Res. 2015, 22, 425-437. [CrossRef]

253. Andersson, C.R.; Tsinoremas, N.F.; Shelton, J.; Lebedeva, N.V.; Yarrow, J.; Min, H.; Golden, S.S. Application of bioluminescence to the study of circadian rhythms in cyanobacteria. Methods Enzymol. 2000, 305. [CrossRef]

254. Niederholtmeyer, H.; Wolfstädter, B.T.; Savage, D.F.; Silver, P.A.; Way, J.C. Engineering cyanobacteria to synthesize and export hydrophilic products. Appl. Environ. Microbiol. 2010, 76, 3462-3466. [CrossRef]

255. Taton, A.; Unglaub, F.; Wright, N.E.; Zeng, W.Y.; Paz-Yepes, J.; Brahamsha, B.; Palenik, B.; Peterson, T.C.; Haerizadeh, F.; Golden, S.S.; et al. Broad-host-range vector system for synthetic biology and biotechnology in cyanobacteria. Nucleic Acids Res. 2014, 42. [CrossRef]

256. Xu, Y.; Alvey, R.M.; Byrne, P.O.; Graham, J.E.; Shen, G.; Bryant, D.A. Expression of genes in cyanobacteria: Adaptation of endogenous plasmids as platforms for high-level gene expression in Synechococcus sp. PCC 7002. Methods Mol. Biol. 2011. [CrossRef]

257. Ruffing, A.M.; Jensen, T.J.; Strickland, L.M. Genetic tools for advancement of Synechococcus sp. PCC 7002 as a cyanobacterial chassis. Microb. Cell Fact. 2016, 15. [CrossRef]

258. Nozzi, N.E.; Case, A.E.; Carroll, A.L.; Atsumi, S. Systematic Approaches to Efficiently Produce 2,3-Butanediol in a Marine Cyanobacterium. ACS Synth. Biol. 2017, 6, 2136-2144. [CrossRef] [PubMed]

259. Mohamed, A.; Jansson, C. Influence of light on accumulation of photosynthesis-specific transcripts in the cyanobacterium Synechocystis 6803. Plant Mol. Biol. 1989, 13, 693-700. [CrossRef]

260. Mohamed, A.; Eriksson, J.; Osiewacz, H.D.; Jansson, C. Differential expression of the psbA genes in the cyanobacterium Synechocystis 6803. MGG Mol. Gen. Genet. 1993, 238, 161-168. [CrossRef]

261. Albers, S.C.; Gallegos, V.A.; Peebles, C.A.M. Engineering of genetic control tools in Synechocystis sp. PCC 6803 using rational design techniques. J. Biotechnol. 2015, 216, 36-46. [CrossRef]

262. Lin, P.-C.; Saha, R.; Zhang, F.; Pakrasi, H.B. Metabolic engineering of the pentose phosphate pathway for enhanced limonene production in the cyanobacterium Synechocystis sp. PCC 6803. Sci. Rep. 2017, 7. [CrossRef] [PubMed]

263. Jin, H.; Wang, Y.; Idoine, A.; Bhaya, D. Construction of a shuttle vector using an endogenous plasmid from the cyanobacterium Synechocystis sp. PCC6803. Front. Microbiol. 2018, 9. [CrossRef] [PubMed]

264. Liu, D.; Pakrasi, H.B. Exploring native genetic elements as plug-in tools for synthetic biology in the cyanobacterium Synechocystis sp. PCC 6803. Microb. Cell Fact. 2018, 17. [CrossRef]

265. Kamennaya, N.A.; Post, A.F. Characterization of cyanate metabolism in marine Synechococcus and Prochlorococcus spp. Appl. Environ. Microbiol. 2011, 29, 76-85. [CrossRef]

266. Kamennaya, N.A.; Ahn, S.E.; Park, H.; Bartal, R.; Sasaki, K.A.; Holman, H.Y.; Jansson, C. Installing extra bicarbonate transporters in the cyanobacterium Synechocystis sp. PCC6803 enhances biomass production. Metab. Eng. 2015. [CrossRef] [PubMed]

267. Varman, A.M.; Xiao, Y.; Pakrasi, H.B.; Tang, Y.J. Metabolic engineering of Synechocystis sp. Strain PCC 6803 for isobutanol production. Appl. Environ. Microbiol. 2013, 79, 908-914. [CrossRef] [PubMed]

268. Lagarde, D.; Beuf, L.; Vermaas, W. Increased production of zeaxanthin and other pigments by application of genetic engineering techniques to Synechocystis sp. strain PCC 6803. Appl. Environ. Microbiol. 2000, 66, 64-72. [CrossRef] [PubMed] 
269. Horiuchi, M.; Nakamura, K.; Kojima, K.; Nishiyama, Y.; Hatakeyama, W.; Hisabori, T.; Hihara, Y. The PedR transcriptional regulator interacts with thioredoxin to connect photosynthesis with gene expression in cyanobacteria. Biochem. J. 2010, 431, 135-140. [CrossRef]

270. Reinsvold, R.E.; Jinkerson, R.E.; Radakovits, R.; Posewitz, M.C.; Basu, C. The production of the sesquiterpene $\beta$-caryophyllene in a transgenic strain of the cyanobacterium Synechocystis. J. Plant Physiol. 2011, 168, 848-852. [CrossRef]

271. Nagarajan, A.; Winter, R.; Eaton-Rye, J.; Burnap, R. A synthetic DNA and fusion PCR approach to the ectopic expression of high levels of the D1 protein of photosystem II in Synechocystis sp. PCC 6803. J. Photochem. Photobiol. B Biol. 2011, 104, 212-219. [CrossRef]

272. Khetkorn, W.; Incharoensakdi, A.; Lindblad, P.; Jantaro, S. Enhancement of poly-3-hydroxybutyrate production in Synechocystis sp. PCC 6803 by overexpression of its native biosynthetic genes. Bioresour. Technol. 2016, 214, 761-768. [CrossRef]

273. Lindberg, P.; Park, S.; Melis, A. Engineering a platform for photosynthetic isoprene production in cyanobacteria, using Synechocystis as the model organism. Metab. Eng. 2010, 12, 70-79. [CrossRef] [PubMed]

274. Bentley, F.K.; Melis, A. Diffusion-based process for carbon dioxide uptake and isoprene emission in gaseous/aqueous two-phase photobioreactors by photosynthetic microorganisms. Biotechnol. Bioeng. 2012, 109. [CrossRef]

275. Bentley, F.K.; Zurbriggen, A.; Melis, A. Heterologous expression of the mevalonic acid pathway in cyanobacteria enhances endogenous carbon partitioning to isoprene. Mol. Plant 2014, 7, 71-86. [CrossRef]

276. Kudoh, K.; Hotta, S.; Sekine, M.; Fujii, R.; Uchida, A.; Kubota, G.; Kawano, Y.; Ihara, M. Overexpression of endogenous 1-deoxyD-xylulose 5-phosphate synthase (DXS) in cyanobacterium Synechocystis sp. PCC6803 accelerates protein aggregation. J. Biosci. Bioeng. 2017, 123, 590-596. [CrossRef]

277. Englund, E.; Shabestary, K.; Hudson, E.P.; Lindberg, P. Systematic overexpression study to find target enzymes enhancing production of terpenes in Synechocystis PCC 6803, using isoprene as a model compound. Metab. Eng. 2018, 49, 164-177. [CrossRef] [PubMed]

278. Eungrasamee, K.; Miao, R.; Incharoensakdi, A.; Lindblad, P.; Jantaro, S. Improved lipid production via fatty acid biosynthesis and free fatty acid recycling in engineered Synechocystis sp. PCC 6803. Biotechnol. Biofuels 2019, 12. [CrossRef] [PubMed]

279. Brey, L.F.; Włodarczyk, A.J.; Bang Thøfner, J.F.; Burow, M.; Crocoll, C.; Nielsen, I.; Zygadlo Nielsen, A.J.; Jensen, P.E. Metabolic engineering of Synechocystis sp. PCC 6803 for the production of aromatic amino acids and derived phenylpropanoids. Metab. Eng. 2020, 57, 129-139. [CrossRef] [PubMed]

280. Deshpande, A.; Vue, J.; Morgan, J. Combining random mutagenesis and metabolic engineering for enhanced tryptophan production in Synechocystis sp. strain PCC 6803. Appl. Environ. Microbiol. 2020, 86. [CrossRef]

281. Bersanini, L.; Battchikova, N.; Jokel, M.; Rehman, A.; Vass, I.; Allahverdiyeva, Y.; Aro, E.M. Flavodiiron protein Flv2/Flv4-related photoprotective mechanism dissipates excitation pressure of PSII in cooperation with phycobilisomes in cyanobacteria. Plant Physiol. 2014, 164, 805-818. [CrossRef]

282. Mustila, H.; Paananen, P.; Battchikova, N.; Santana-Sánchez, A.; Muth-Pawlak, D.; Hagemann, M.; Aro, E.M.; Allahverdiyeva, Y. The flavodiiron protein Flv3 functions as a homo-oligomer during stress acclimation and is distinct from the Flv1/Flv3 heterooligomer specific to the $\mathrm{O}_{2}$ photoreduction pathway. Plant Cell Physiol. 2016, 57, 1468-1483. [CrossRef] [PubMed]

283. Chaves, J.E.; Romero, P.R.; Kirst, H.; Melis, A. Role of isopentenyl-diphosphate isomerase in heterologous cyanobacterial (Synechocystis) isoprene production. Photosynth. Res. 2016, 130, 517-527. [CrossRef] [PubMed]

284. Chaves, J.E.; Rueda-Romero, P.; Kirst, H.; Melis, A. Engineering Isoprene Synthase Expression and Activity in Cyanobacteria. ACS Synth. Biol. 2017, 6, 2281-2292. [CrossRef]

285. Formighieri, C.; Melis, A. Heterologous synthesis of geranyllinalool, a diterpenol plant product, in the cyanobacterium Synechocystis. Appl. Microbiol. Biotechnol. 2017, 101, 2791-2800. [CrossRef] [PubMed]

286. Sivaramakrishnan, R.; Incharoensakdi, A. Enhancement of lipid production in Synechocystis sp. PCC 6803 overexpressing glycerol kinase under oxidative stress with glycerol supplementation. Bioresour. Technol. 2018, 267, 532-540. [CrossRef] [PubMed]

287. Chaves, J.E.; Melis, A. Biotechnology of cyanobacterial isoprene production. Appl. Microbiol. Biotechnol. 2018, 102, 6452-6458. [CrossRef] [PubMed]

288. Formighieri, C.; Melis, A. Regulation of $\beta$-phellandrene synthase gene expression, recombinant protein accumulation, and monoterpene hydrocarbons production in Synechocystis transformants. Planta 2014, 240, 309-324. [CrossRef]

289. Formighieri, C.; Melis, A. A phycocyanin phellandrene synthase fusion enhances recombinant protein expression and $\beta$ phellandrene (monoterpene) hydrocarbons production in Synechocystis (cyanobacteria). Metab. Eng. 2015, 32, 116-124. [CrossRef] [PubMed]

290. Formighieri, C.; Melis, A. Sustainable heterologous production of terpene hydrocarbons in cyanobacteria. Photosynth. Res. 2016, 130, 123-135. [CrossRef]

291. Betterle, N.; Melis, A. Heterologous Leader Sequences in Fusion Constructs Enhance Expression of Geranyl Diphosphate Synthase and Yield of $\beta$-Phellandrene Production in Cyanobacteria (Synechocystis). ACS Synth. Biol. 2018, 7, 912-921. [CrossRef]

292. Betterle, N.; Melis, A. Photosynthetic generation of heterologous terpenoids in cyanobacteria. Biotechnol. Bioeng. 2019, 116, 2041-2051. [CrossRef]

293. Valsami, E.A.; Psychogyiou, M.E.; Pateraki, A.; Chrysoulaki, E.; Melis, A.; Ghanotakis, D.F. Fusion constructs enhance heterologous $\beta$-phellandrene production in Synechocystis sp. PCC 6803. J. Appl. Phycol. 2020. [CrossRef] 
294. Marbouty, M.; Mazouni, K.; Saguez, C.; Cassier-Chauvat, C.; Chauvat, F. Characterization of the Synechocystis strain PCC 6803 penicillin-binding proteins and cytokinetic proteins FtsQ and FtsW and their network of interactions with ZipN. J. Bacteriol. 2009, 191, 5123-5133. [CrossRef] [PubMed]

295. Xue, Y.; Zhang, Y.; Cheng, D.; Daddy, S.; He, Q. Genetically engineering Synechocystis sp. Pasteur Culture Collection 6803 for the sustainable production of the plant secondary metabolite p-coumaric acid. Proc. Natl. Acad. Sci. USA 2014, 111, 9449-9454. [CrossRef]

296. Aoki, S.; Kondo, T.; Ishiura, M. Circadian expression of the dnaK gene in the cyanobacterium Synechocystis sp. strain PCC 6803. J. Bacteriol. 1995, 177, 5606-5611. [CrossRef] [PubMed]

297. Peca, L.; Kós, P.B.; Máté, Z.; Farsang, A.; Vass, I. Construction of bioluminescent cyanobacterial reporter strains for detection of nickel, cobalt and zinc. FEMS Microbiol. Lett. 2008, 1837, 1293-1304. [CrossRef] [PubMed]

298. Muramatsu, M.; Hihara, Y. Transcriptional regulation of genes encoding subunits of photosystem I during acclimation to high-light conditions in Synechocystis sp. PCC 6803. Planta 2003, 216, 446-453. [CrossRef]

299. Takahashi, T.; Nakai, N.; Muramatsu, M.; Hihara, Y. Role of multiple HLR1 sequences in the regulation of the dual promoters of the psaAB genes in Synechocystis sp. PCC 6803. J. Bacteriol. 2010, 192, 4031-4036. [CrossRef]

300. Rutherford, J.C.; Cavet, J.S.; Robinson, N.J. Cobalt-dependent transcriptional switching by a dual-effector MerR-like protein regulates a cobalt-exporting variant CPx-type ATPase. J. Biol. Chem. 1999, 274, 25827-25832. [CrossRef]

301. Calderon, R.H.; García-Cerdán, J.G.; Malnoë, A.; Cook, R.; Russell, J.J.; Gaw, C.; Dent, R.M.; De Vitry, C.; Niyogi, K.K. A conserved rubredoxin is necessary for photosystem II accumulation in diverse oxygenic photoautotrophs. J. Biol. Chem. 2013, 288, 26688-26696. [CrossRef]

302. Ke, W.T.; Dai, G.Z.; Jiang, H.B.; Zhang, R.; Qiu, B.S. Essential roles of iron superoxide dismutase in photoautotrophic growth of Synechocystis sp. PCC 6803 and heterogeneous expression of marine Synechococcus sp. CC9311 copper/zinc superoxide dismutase within its sodB knockdown mutant. Microbiology (UK) 2014, 160, 228-241. [CrossRef] [PubMed]

303. Kunert, A.; Hagemann, M.; Erdmann, N. Construction of promoter probe vectors for Synechocystis sp. PCC 6803 using the light-emitting reporter systems Gfp and LuxAB. J. Microbiol. Methods 2000, 41, 185-194. [CrossRef]

304. Tan, X.; Yao, L.; Gao, Q.; Wang, W.; Qi, F.; Lu, X. Photosynthesis driven conversion of carbon dioxide to fatty alcohols and hydrocarbons in cyanobacteria. Metab. Eng. 2011, 13, 169-176. [CrossRef]

305. Ungerer, J.; Tao, L.; Davis, M.; Ghirardi, M.; Maness, P.C.; Yu, J. Sustained photosynthetic conversion of $\mathrm{CO}_{2}$ to ethylene in recombinant cyanobacterium Synechocystis 6803. Energy Environ. Sci. 2012, 5, 8998-9006. [CrossRef]

306. Veetil, V.P.; Angermayr, S.A.; Hellingwerf, K.J. Ethylene production with engineered Synechocystis sp PCC 6803 strains. Microb. Cell Fact. 2017, 16. [CrossRef] [PubMed]

307. Angermayr, S.A.; Paszota, M.; Hellingwerf, K.J. Engineering a cyanobacterial cell factory for production of lactic acid. Appl. Environ. Microbiol. 2012, 78, 7098-7106. [CrossRef]

308. Angermayr, S.A.; Van Der Woude, A.D.; Correddu, D.; Vreugdenhil, A.; Verrone, V.; Hellingwerf, K.J. Exploring metabolic engineering design principles for the photosynthetic production of lactic acid by Synechocystis sp. PCC6803. Biotechnol. Biofuels 2014, 7. [CrossRef]

309. Van der Woude, A.D.; Angermayr, S.A.; Puthan Veetil, V.; Osnato, A.; Hellingwerf, K.J. Carbon sink removal: Increased photosynthetic production of lactic acid by Synechocystis sp. PCC6803 in a glycogen storage mutant. J. Biotechnol. 2014, 184, 100-102. [CrossRef] [PubMed]

310. Hidese, R.; Matsuda, M.; Osanai, T.; Hasunuma, T.; Kondo, A. Malic Enzyme Facilitates d -Lactate Production through Increased Pyruvate Supply during Anoxic Dark Fermentation in Synechocystis sp. PCC 6803. ACS Synth. Biol. 2020, 9, 260-268. [CrossRef] [PubMed]

311. Savakis, P.E.; Angermayr, S.A.; Hellingwerf, K.J. Synthesis of 2,3-butanediol by Synechocystis sp. PCC6803 via heterologous expression of a catabolic pathway from lactic acid- and enterobacteria. Metab. Eng. 2013, 20, 121-130. [CrossRef] [PubMed]

312. Du, W.; Liang, F.; Duan, Y.; Tan, X.; Lu, X. Exploring the photosynthetic production capacity of sucrose by cyanobacteria. Metab. Eng. 2013, 19, 17-25. [CrossRef] [PubMed]

313. Viola, S.; Rühle, T.; Leister, D. A single vector-based strategy for marker-less gene replacement in Synechocystis sp. PCC 6803. Microb. Cell Fact. 2014, 13. [CrossRef] [PubMed]

314. Yao, L.; Qi, F.; Tan, X.; Lu, X. Improved production of fatty alcohols in cyanobacteria by metabolic engineering. Biotechnol. Biofuels 2014, 7. [CrossRef] [PubMed]

315. Yoshikawa, K.; Hirasawa, T.; Shimizu, H. Effect of malic enzyme on ethanol production by Synechocystis sp. PCC 6803. J. Biosci. Bioeng. 2015, 119, 82-84. [CrossRef]

316. Namakoshi, K.; Nakajima, T.; Yoshikawa, K.; Toya, Y.; Shimizu, H. Combinatorial deletions of glgC and phaCE enhance ethanol production in Synechocystis sp. PCC 6803. J. Biotechnol. 2016, 239, 13-19. [CrossRef]

317. Bartasun, P.; Prandi, N.; Storch, M.; Aknin, Y.; Bennett, M.; Palma, A.; Baldwin, G.; Sakuragi, Y.; Jones, P.R.; Rowland, J. The effect of modulating the quantity of enzymes in a model ethanol pathway on metabolic flux in Synechocystis sp. PCC 6803. PeerJ 2019, 7. [CrossRef] [PubMed]

318. Savakis, P.; Tan, X.; Du, W.; Branco Dos Santos, F.; Lu, X.; Hellingwerf, K.J. Photosynthetic production of glycerol by a recombinant cyanobacterium. J. Biotechnol. 2015, 195, 46-51. [CrossRef] 
319. Anfelt, J.; Kaczmarzyk, D.; Shabestary, K.; Renberg, B.; Rockberg, J.; Nielsen, J.; Uhlén, M.; Hudson, E.P. Genetic and nutrient modulation of acetyl-CoA levels in Synechocystis for n-butanol production. Microb. Cell Fact. 2015, 14. [CrossRef]

320. Hu, J.; Li, T.; Xu, W.; Zhan, J.; Chen, H.; He, C.; Wang, Q. Small antisense RNA RblR positively regulates RuBisCo in Synechocystis sp. PCC 6803. Front. Microbiol. 2017. [CrossRef]

321. Wang, B.; Eckert, C.; Maness, P.C.; Yu, J. A Genetic Toolbox for Modulating the Expression of Heterologous Genes in the Cyanobacterium Synechocystis sp. PCC 6803. ACS Synth. Biol. 2018, 7, 276-286. [CrossRef]

322. David, C.; Schmid, A.; Adrian, L.; Wilde, A.; Bühler, K. Production of 1,2-propanediol in photoautotrophic Synechocystis is linked to glycogen turn-over. Biotechnol. Bioeng. 2018, 115, 300-311. [CrossRef] [PubMed]

323. Qiao, Y.; Wang, W.; Lu, X. High Light Induced Alka(e)ne Biodegradation for Lipid and Redox Homeostasis in Cyanobacteria. Front. Microbiol. 2020, 11. [CrossRef] [PubMed]

324. Wu, W.; Du, W.; Gallego, R.P.; Hellingwerf, K.J.; Van Der Woude, A.D.; Dos Santos, F.B. Using osmotic stress to stabilize mannitol production in Synechocystis sp. PCC6803. Biotechnol. Biofuels 2020, 13. [CrossRef] [PubMed]

325. Sebesta, J.; Peebles, C.A. Improving heterologous protein expression in Synechocystis sp. PCC 6803 for alpha-bisabolene production. Metab. Eng. Commun. 2020, 10. [CrossRef] [PubMed]

326. Gao, Z.; Zhao, H.; Li, Z.; Tan, X.; Lu, X. Photosynthetic production of ethanol from carbon dioxide in genetically engineered cyanobacteria. Energy Environ. Sci. 2012, 5, 9857-9865. [CrossRef]

327. Wang, W.; Liu, X.; Lu, X. Engineering cyanobacteria to improve photosynthetic production of alka(e)nes. Biotechnol. Biofuels 2013, 6. [CrossRef]

328. Immethun, C.M.; DeLorenzo, D.M.; Focht, C.M.; Gupta, D.; Johnson, C.B.; Moon, T.S. Physical, chemical, and metabolic state sensors expand the synthetic biology toolbox for Synechocystis sp. PCC 6803. Biotechnol. Bioeng. 2017, 114, 1561-1569. [CrossRef]

329. Gao, Q.; Wang, W.; Zhao, H.; Lu, X. Effects of fatty acid activation on photosynthetic production of fatty acid-based biofuels in Synechocystis sp. PCC6803. Biotechnol. Biofuels 2012, 5. [CrossRef] [PubMed]

330. Lee, T.C.; Xiong, W.; Paddock, T.; Carrieri, D.; Chang, I.F.; Chiu, H.F.; Ungerer, J.; Hank Juo, S.H.; Maness, P.C.; Yu, J. Engineered xylose utilization enhances bio-products productivity in the cyanobacterium Synechocystis sp. PCC 6803. Metab. Eng. 2015, 30, 179-189. [CrossRef]

331. Hein, S.; Tran, H.; Steinbüchel, A. Synechocystis sp. PCC6803 possesses a two-component polyhydroxyalkanoic acid synthase similar to that of anoxygenic purple sulfur bacteria. Arch. Microbiol. 1998, 170, 162-170. [CrossRef]

332. Zhou, J.; Zhang, H.; Zhang, Y.; Li, Y.; Ma, Y. Designing and creating a modularized synthetic pathway in cyanobacterium Synechocystis enables production of acetone from carbon dioxide. Metab. Eng. 2012, 14, 394-400. [CrossRef]

333. Cameron, J.C.; Pakrasi, H.B. Essential role of glutathione in acclimation to environmental and redox perturbations in the cyanobacterium Synechocystis sp. PCC 6803. Plant Physiol. 2010, 154, 1672-1685. [CrossRef]

334. Aoki, R.; Goto, T.; Fujita, Y. A heme oxygenase isoform is essential for aerobic growth in the cyanobacterium Synechocystis sp. PCC 6803: Modes of differential operation of two isoforms/enzymes to adapt to low oxygen environments in cyanobacteria. Plant Cell Physiol. 2011, 52, 1744-1756. [CrossRef] [PubMed]

335. Osanai, T.; Oikawa, A.; Numata, K.; Kuwahara, A.; Iijima, H.; Doi, Y.; Saito, K.; Hirai, M.Y. Pathway-level acceleration of glycogen catabolism by a response regulator in the cyanobacterium Synechocystis species PCC 6803. Plant Physiol. 2014, 164, $1831-1841$. [CrossRef]

336. Hasunuma, T.; Matsuda, M.; Senga, Y.; Aikawa, S.; Toyoshima, M.; Shimakawa, G.; Miyake, C.; Kondo, A. Overexpression of flv3 improves photosynthesis in the cyanobacterium Synechocystis sp. PCC6803 by enhancement of alternative electron flow. Biotechnol. Biofuels 2014, 7. [CrossRef]

337. Tashiro, M.; Kiyota, H.; Kawai-Noma, S.; Saito, K.; Ikeuchi, M.; Iijima, Y.; Umeno, D. Bacterial Production of Pinene by a Laboratory-Evolved Pinene-Synthase. ACS Synth. Biol. 2016, 5. [CrossRef]

338. Englund, E.; Liang, F.; Lindberg, P. Evaluation of promoters and ribosome binding sites for biotechnological applications in the unicellular cyanobacterium Synechocystis sp. PCC 6803. Sci. Rep. 2016, 6. [CrossRef]

339. Behler, J.; Vijay, D.; Hess, W.R.; Akhtar, M.K. CRISPR-Based Technologies for Metabolic Engineering in Cyanobacteria. Trends Biotechnol. 2018, 36, 996-1010. [CrossRef] [PubMed]

340. Durall, C.; Lindberg, P.; Yu, J.; Lindblad, P. Increased ethylene production by overexpressing phosphoenolpyruvate carboxylase in the cyanobacterium Synechocystis PCC 6803. Biotechnol. Biofuels 2020, 13. [CrossRef] [PubMed]

341. Matsudaira, A.; Hoshino, Y.; Uesaka, K.; Takatani, N.; Omata, T.; Usuda, Y. Production of glutamate and stereospecific flavors, (S)-linalool and (+)-valencene, by Synechocystis sp. PCC6803. J. Biosci. Bioeng. 2020, 130, 464-470. [CrossRef]

342. Kiyota, H.; Okuda, Y.; Ito, M.; Hirai, M.Y.; Ikeuchi, M. Engineering of cyanobacteria for the photosynthetic production of limonene from $\mathrm{CO}_{2}$. J. Biotechnol. 2014, 185, 1-7. [CrossRef] [PubMed]

343. Wang, Y.; Sun, T.; Gao, X.; Shi, M.; Wu, L.; Chen, L.; Zhang, W. Biosynthesis of platform chemical 3-hydroxypropionic acid (3-HP) directly from $\mathrm{CO}_{2}$ in cyanobacterium Synechocystis sp. PCC 6803. Metab. Eng. 2016, 34, 60-70. [CrossRef]

344. Englund, E.; Andersen-Ranberg, J.; Miao, R.; Hamberger, B.; Lindberg, P. Metabolic Engineering of Synechocystis sp. PCC 6803 for Production of the Plant Diterpenoid Manoyl Oxide. ACS Synth. Biol. 2015, 4, 1270-1278. [CrossRef]

345. Shabestary, K.; Anfelt, J.; Ljungqvist, E.; Jahn, M.; Yao, L.; Hudson, E.P. Targeted Repression of Essential Genes to Arrest Growth and Increase Carbon Partitioning and Biofuel Titers in Cyanobacteria. ACS Synth. Biol. 2018, 7, 1669-1675. [CrossRef] [PubMed] 
346. Wang, B.; Pugh, S.; Nielsen, D.R.; Zhang, W.; Meldrum, D.R. Engineering cyanobacteria for photosynthetic production of 3-hydroxybutyrate directly from $\mathrm{CO}_{2}$. Metab. Eng. 2013, 16, 68-77. [CrossRef]

347. Li, H.; Liao, J.C. Engineering a cyanobacterium as the catalyst for the photosynthetic conversion of $\mathrm{CO}_{2}$ to $1,2-$ propanediol. Microb. Cell Fact. 2013, 12. [CrossRef]

348. Wang, Y.; Tao, F.; Ni, J.; Li, C.; Xu, P. Production of $\mathrm{C}_{3}$ platform chemicals from $\mathrm{CO}_{2}$ by genetically engineered cyanobacteria. Green Chem. 2015, 17. [CrossRef]

349. Li, C.; Tao, F.; Ni, J.; Wang, Y.; Yao, F.; Xu, P. Enhancing the light-driven production of d-lactate by engineering cyanobacterium using a combinational strategy. Sci. Rep. 2015, 5, 9777. [CrossRef]

350. Lan, E.I.; Wei, C.T. Metabolic engineering of cyanobacteria for the photosynthetic production of succinate. Metab. Eng. 2016, 38, 483-493. [CrossRef]

351. Carbonell, V.; Vuorio, E.; Aro, E.M.; Kallio, P. Enhanced stable production of ethylene in photosynthetic cyanobacterium Synechococcus elongatus PCC 7942. World J. Microbiol. Biotechnol. 2019, 35, 77. [CrossRef]

352. Velmurugan, R.; Incharoensakdi, A. Heterologous Expression of Ethanol Synthesis Pathway in Glycogen Deficient Synechococcus elongatus PCC 7942 Resulted in Enhanced Production of Ethanol and Exopolysaccharides. Front Plant Sci 2020, 11. [CrossRef] [PubMed]

353. Ruffing, A.M.; Jones, H.D.T. Physiological effects of free fatty acid production in genetically engineered Synechococcus elongatus PCC 7942. Biotechnol. Bioeng. 2012, 109, 2190-2199. [CrossRef]

354. Ruffing, A.M. Borrowing genes from Chlamydomonas reinhardtii for free fatty acid production in engineered cyanobacteria. J. Appl. Phycol. 2013, 25, 1495-1507. [CrossRef]

355. Ruffing, A.M. Improved free fatty acid production in cyanobacteria with Synechococcus sp. PCC 7002 as host. Front. Bioeng. Biotechnol. 2014, 2, 1-10. [CrossRef] [PubMed]

356. Kachel, B.; Mack, M. Engineering of Synechococcus sp. strain PCC 7002 for the photoautotrophic production of light-sensitive riboflavin (vitamin B2). Metab. Eng. 2020, 62, 275-286. [CrossRef]

357. Jazmin, L.J.; Xu, Y.; Cheah, Y.E.; Adebiyi, A.O.; Johnson, C.H.; Young, J.D. Isotopically nonstationary $13 \mathrm{C}$ flux analysis of cyanobacterial isobutyraldehyde production. Metab. Eng. 2017, 42, 9-18. [CrossRef]

358. Sommer, M.; Sutter, M.; Gupta, S.; Kirst, H.; Turmo, A.; Lechno-Yossef, S.; Burton, R.L.; Saechao, C.; Sloan, N.B.; Cheng, X.; et al. Heterohexamers formed by $\mathrm{C} c \mathrm{KK} 3$ and $\mathrm{CcmK} 4$ increase the complexity of beta carboxysome shells. Plant Physiol. 2019, 179, 156-167. [CrossRef]

359. Clerico, E.M.; Cassone, V.M.; Golden, S.S. Stability and lability of circadian period of gene expression in the cyanobacterium Synechococcus elongatus. Microbiology 2009, 155, 635-641. [CrossRef]

360. Atsumi, S.; Higashide, W.; Liao, J.C. Direct photosynthetic recycling of carbon dioxide to isobutyraldehyde. Nat. Biotechnol. 2009, 27, 1177-1180. [CrossRef] [PubMed]

361. Lan, E.I.; Liao, J.C. Metabolic engineering of cyanobacteria for 1-butanol production from carbon dioxide. Metab. Eng. 2011, 13, 353-363. [CrossRef]

362. Lan, E.I.; Liao, J.C. ATP drives direct photosynthetic production of 1-butanol in cyanobacteria. Proc. Natl. Acad. Sci. USA 2012, 109, 6018-6023. [CrossRef] [PubMed]

363. Cameron, J.C.; Wilson, S.C.; Bernstein, S.L.; Kerfeld, C.A. Biogenesis of a bacterial organelle: The carboxysome assembly pathway. Cell 2013, 155, 1131-1140. [CrossRef] [PubMed]

364. Chen, A.H.; Robinson-Mosher, A.; Savage, D.F.; Silver, P.A.; Polka, J.K. The Bacterial Carbon-Fixing Organelle Is Formed by Shell Envelopment of Preassembled Cargo. PLoS ONE 2013, 8, e76127. [CrossRef] [PubMed]

365. Kusakabe, T.; Tatsuke, T.; Tsuruno, K.; Hirokawa, Y.; Atsumi, S.; Liao, J.C.; Hanai, T. Engineering a synthetic pathway in cyanobacteria for isopropanol production directly from carbon dioxide and light. Metab. Eng. 2013, 20, 101-108. [CrossRef]

366. Li, X.; Shen, C.R.; Liao, J.C. Isobutanol production as an alternative metabolic sink to rescue the growth deficiency of the glycogen mutant of Synechococcus elongatus PCC 7942. Photosynth. Res. 2014, 120, 301-310. [CrossRef]

367. Lan, E.I.; Chuang, D.S.; Shen, C.R.; Lee, A.M.; Ro, S.Y.; Liao, J.C. Metabolic engineering of cyanobacteria for photosynthetic 3-hydroxypropionic acid production from $\mathrm{CO}_{2}$ using Synechococcus elongatus PCC 7942. Metab. Eng. 2015, 31, 163-170. [CrossRef] [PubMed]

368. Hirokawa, Y.; Maki, Y.; Tatsuke, T.; Hanai, T. Cyanobacterial production of 1,3-propanediol directly from carbon dioxide using a synthetic metabolic pathway. Metab. Eng. 2016, 34, 97-103. [CrossRef]

369. Wang, X.; Liu, W.; Xin, C.; Zheng, Y.; Cheng, Y.; Sun, S.; Li, R.; Zhu, X.-G.; Dai, S.Y.; Rentzepis, P.M.; et al. Enhanced limonene production in cyanobacteria reveals photosynthesis limitations. Proc. Natl. Acad. Sci. USA 2016, 113, 14225-14230. [CrossRef]

370. Chwa, J.W.; Kim, W.J.; Sim, S.J.; Um, Y.; Woo, H.M. Engineering of a modular and synthetic phosphoketolase pathway for photosynthetic production of acetone from $\mathrm{CO}_{2}$ in Synechococcus elongatus PCC 7942 under light and aerobic condition. Plant Biotechnol. J. 2016, 14, 1768-1776. [CrossRef]

371. Gao, X.; Gao, F.; Liu, D.; Zhang, H.; Nie, X.; Yang, C. Engineering the methylerythritol phosphate pathway in cyanobacteria for photosynthetic isoprene production from $\mathrm{CO}_{2}$. Energy Environ. Sci. 2016, 7, 71-86. [CrossRef]

372. Taton, A.; Ma, A.T.; Ota, M.; Golden, S.S.; Golden, J.W. NOT Gate Genetic Circuits to Control Gene Expression in Cyanobacteria. ACS Synth. Biol. 2017, 6, 2175. [CrossRef] 
373. Kanno, M.; Atsumi, S. Engineering an Obligate photoautotrophic cyanobacterium to utilize glycerol for growth and chemical production. ACS Synth. Biol. 2017, 6, 69-75. [CrossRef] [PubMed]

374. Lee, H.J.; Lee, J.; Lee, S.-M.; Um, Y.; Kim, Y.; Sim, S.J.; Choi, J.-I.; Woo, H.M. Direct Conversion of $\mathrm{CO}_{2}$ to $\alpha$-Farnesene Using Metabolically Engineered Synechococcus elongatus PCC 7942. J. Agric. Food Chem. 2017, 60, 10424-10428. [CrossRef] [PubMed]

375. Pattharaprachayakul, N.; Lee, H.J.; Incharoensakdi, A.; Woo, H.M. Evolutionary Engineering of Cyanobacteria to Enhance the Production of $\alpha$-Farnesene from $\mathrm{CO}_{2}$. J. Agric. Food Chem. 2019, 67, 13658-13664. [CrossRef] [PubMed]

376. Hirokawa, Y.; Goto, R.; Umetani, Y.; Hanai, T. Construction of a novel D-lactate producing pathway from dihydroxyacetone phosphate of the Calvin cycle in cyanobacterium, Synechococcus elongatus PCC 7942. J. Biosci. Bioeng. 2017, 124, 54-61. [CrossRef] [PubMed]

377. Ducat, D.C.; Avelar-Rivas, J.A.; Way, J.C.; Silvera, P.A. Rerouting carbon flux to enhance photosynthetic productivity. Appl. Environ. Microbiol. 2012, 78, 2660-2668. [CrossRef] [PubMed]

378. Shih, P.M.; Zarzycki, J.; Niyogi, K.K.; Kerfeld, C.A. Introduction of a synthetic $\mathrm{CO}_{2}$-fixing photorespiratory bypass into a cyanobacterium. J. Biol. Chem. 2014, 289, 9493-9500. [CrossRef]

379. Oliver, J.W.K.; Atsumi, S. A carbon sink pathway increases carbon productivity in cyanobacteria. Metab. Eng. 2015, 29, 106-112. [CrossRef]

380. Choi, S.Y.; Sim, S.J.; Choi, J.I.; Woo, H.M. Identification of small droplets of photosynthetic squalene in engineered Synechococcus elongatus PCC 7942 using TEM and selective fluorescent Nile red analysis. Lett. Appl. Microbiol. 2018, 66, 523-529. [CrossRef]

381. Kim, W.J.; Lee, S.M.; Um, Y.; Sim, S.J.; Woo, H.M. Development of synebrick vectors as a synthetic biology platform for gene expression in Synechococcus elongatus PCC 7942. Front. Plant Sci. 2017, 8. [CrossRef]

382. Roulet, J.; Taton, A.; Golden, J.W.; Arabolaza, A.; Burkart, M.D.; Gramajo, H. Development of a cyanobacterial heterologous polyketide production platform. Metab. Eng. 2018, 49, 94-104. [CrossRef] [PubMed]

383. Takahama, K.; Matsuoka, M.; Nagahama, K.; Ogawa, T. Construction and analysis of a recombinant cyanobacterium expressing a chromosomally inserted gene for an ethylene-forming enzyme at the psbAI locus. J. Biosci. Bioeng. 2003, 15, 302-305. [CrossRef]

384. Oliver, J.W.K.; Machado, I.M.P.; Yoneda, H.; Atsumi, S. Cyanobacterial conversion of carbon dioxide to 2,3-butanediol. Proc. Natl. Acad. Sci. USA 2013, 110, 1249-1254. [CrossRef]

385. Peterson, E.S.; McCue, L.A.; Schrimpe-Rutledge, A.C.; Jensen, J.L.; Walker, H.; Kobold, M.A.; Webb, S.R.; Payne, S.H.; Ansong, C.; Adkins, J.N.; et al. VESPA: Software to facilitate genomic annotation of prokaryotic organisms through integration of proteomic and transcriptomic data. BMC Genom. 2012, 13. [CrossRef]

386. Begemann, M.B.; Zess, E.K.; Walters, E.M.; Schmitt, E.F.; Markley, A.L.; Pfleger, B.F. An Organic Acid Based Counter Selection System for Cyanobacteria. PLoS ONE 2013, 8, e76594. [CrossRef]

387. Clark, R.L.; Gordon, G.C.; Bennett, N.R.; Lyu, H.; Root, T.W.; Pfleger, B.F. High- $\mathrm{CO}_{2}$ Requirement as a Mechanism for the Containment of Genetically Modified Cyanobacteria. ACS Synth. Biol. 2018, 7, 384-391. [CrossRef] [PubMed]

388. Markley, A.L.; Begemann, M.B.; Clarke, R.E.; Gordon, G.C.; Pfleger, B.F. Synthetic Biology Toolbox for Controlling Gene Expression in the Cyanobacterium Synechococcus sp. strain PCC 7002. ACS Synth. Biol. 2015, 4, 595-603. [CrossRef] [PubMed]

389. Sakamoto, T.; Shen, G.; Higashi, S.; Murata, N.; Bryant, D.A. Alteration of low-temperature susceptibility of the cyanobacterium Synechococcus sp. PCC 7002 by genetic manipulation of membrane lipid unsaturation. Arch. Microbiol. 1997, 169, 20-28. [CrossRef] [PubMed]

390. Vogel, A.I.M.; Lale, R.; Hohmann-Marriott, M.F. Streamlining recombination-mediated genetic engineering by validating three neutral integration sites in Synechococcus sp. PCC 7002. J. Biol. Eng. 2017, 11. [CrossRef]

391. Selão, T.T.; Włodarczyk, A.; Nixon, P.J.; Norling, B. Growth and selection of the cyanobacterium Synechococcus sp. PCC 7002 using alternative nitrogen and phosphorus sources. Metab. Eng. 2019, 54, 2. [CrossRef]

392. Korosh, T.C.; Markley, A.L.; Clark, R.L.; McGinley, L.L.; McMahon, K.D.; Pfleger, B.F. Engineering photosynthetic production of L-lysine. Metab. Eng. 2017, 44, 273-283. [CrossRef]

393. Daniell, H.; Sarojini, G.; McFadden, B.A. Transformation of the cyanobacterium Anacystis nidulans 6301 with the Escherichia coli plasmid pBR322. Proc. Natl. Acad. Sci. USA 1986, 83, 2546-2550. [CrossRef]

394. Koksharova, O.; Wolk, C. Genetic tools for cyanobacteria. Appl. Microbiol. Biotechnol. 2002, 58, 123-137. [CrossRef]

395. Sherman, L.A.; Van de Putte, P. Construction of a hybrid plasmid capable of replication in the bacterium Escherichia coli and the cyanobacterium Anacystis nidulans. J. Bacteriol. 1982, 150, 410-413. [CrossRef]

396. Golden, S.S.; Sherman, L.A. Optimal conditions for genetic transformation of the cyanobacterium Anacystis nidulans R2. J. Bacteriol. 1984, 158, 36-42. [CrossRef]

397. Buzby, J.S.; Porter, R.D.; Stevens, S.E. Plasmid transformation in Agmenellum quadruplicatum PR-6: Construction of biphasic plasmids and characterization of their transformation properties. J. Bacteriol. 1983, 154, 1446-1450. [CrossRef] [PubMed]

398. Scharnagl, M.; Richter, S.; Hagemann, M. The cyanobacterium Synechocystis sp. strain PCC 6803 expresses a DNA methyltransferase specific for the recognition sequence of the restriction endonuclease PvuI. J. Bacteriol. 1998, 180, 4116-4122. [CrossRef] [PubMed]

399. Wang, B.; Yu, J.; Zhang, W.; Meldrum, D.R. Premethylation of Foreign DNA Improves Integrative Transformation. Appl. Environ. Microbiol. 2015, 81, 8500-8506. [CrossRef] [PubMed] 
400. Hagemann, M.; Gartner, K.; Scharnagl, M.; Bolay, P.; Lott, S.C.; Fuss, J.; Huettel, B.; Reinhardt, R.; Klahn, S.; Hess, W.R. Identification of the DNA methyltransferases establishing the methylome of the cyanobacterium Synechocystis sp. PCC 6803. DNA Res. 2018, 25, 343-352. [CrossRef]

401. Wu, D.; Wang, Y.; Xu, X. Effects of a Type I RM System on Gene Expression and Glycogen Catabolism in Synechocystis sp. PCC 6803. Front. Microbiol. 2020, 11, 1258. [CrossRef]

402. Kuhlemeier, C.J.; Thomas, A.A.M.; van der Ende, A.; van Leen, R.W.; Borrias, W.E.; van den Hondel, C.A.M.J.J.; van Arkel, G.A. A host-vector system for gene cloning in the cyanobacterium Anacystis nidulans R2. Plasmid 1983, 10, 156-163. [CrossRef]

403. Golden, S.S.; Sherman, L.A. A hybrid plasmid is a stable cloning vector for the cyanobacterium Anacystis nidulans R2. J. Bacteriol. 1983, 155, 966-972. [CrossRef] [PubMed]

404. Gendel, S.; Straus, N.; Pulleyblank, D.; Williams, J. Shuttle cloning vectors for the cyanobacterium Anacystis nidulans. J. Bacteriol. 1983, 156, 148-154. [CrossRef] [PubMed]

405. Murphy, R.C.; Bryant, D.A.; Porter, R.D.; Tandeau De Marsac, N. Molecular cloning and characterization of the recA gene from the Cyanobacterium Synechococcus sp. strain PCC 7002. J. Bacteriol. 1987, 172, 967-976. [CrossRef] [PubMed]

406. Kuhlemeier, C.J.; Logtenberg, T.; Stoorvogel, W.; van Heugten, H.A.; Borrias, W.E.; van Arkel, G.A. Cloning of nitrate reductase genes from the cyanobacterium Anacystis nidulans. J. Bacteriol. 1984, 159, 36-41. [CrossRef] [PubMed]

407. Gruber, M.Y.; Glick, B.R.; Thompson, J.E. Cloned manganese superoxide dismutase reduces oxidative stress in Escherichia coli and Anacystis nidulans. Proc. Natl. Acad. Sci. USA 1990, 87, 2608-2612. [CrossRef] [PubMed]

408. Ferino, F.; Chauvat, F. A promoter-probe vector-host system for the cyanobacterium, Synechocystis PCC6803. Gene 1989, 84, 257-266. [CrossRef]

409. Marraccini, P.; Bulteau, S.; Cassier-Chauvat, C.; Mermet-Bouvier, P.; Chauvat, F. A conjugative plasmid vector for promoter analysis in several cyanobacteria of the genera Synechococcus and Synechocystis. Plant Mol. Biol. 1993, 23, 905-909. [CrossRef]

410. Chenebault, C.; Diaz-Santos, E.; Kammerscheit, X.; Görgen, S.; Ilioaia, C.; Streckaite, S.; Gall, A.; Robert, B.; Marcon, E.; Buisson, D.-A.; et al. A Genetic Toolbox for the New Model Cyanobacterium Cyanothece PCC 7425: A Case Study for the Photosynthetic Production of Limonene. Front. Microbiol. 2020, 11, 586-601. [CrossRef]

411. Murphy, R.C.; Stevens, S.E. Cloning and expression of the cryIVD gene of Bacillus thuringiensis subsp. israelensis in the cyanobacterium Agmenellum quadruplicatum PR-6 and its resulting larvicidal activity. Appl. Environ. Microbiol. 1992, 58, 1650-1655. [CrossRef] [PubMed]

412. Soltes-Rak, E.; Kushner, D.J.; Williams, D.D.; Coleman, J.R. Effect of promoter modification on mosquitocidal cryIVB gene expression in Synechococcus sp. strain PCC 7942. Appl. Environ. Microbiol. 1993, 59, 2404-2410. [CrossRef]

413. Erbe, J.L.; Taylor, K.B.; Hall, L.M. Expression of mouse metallothionein in the cyanobacterium Synechococcus PCC7942. J. Ind. Microbiol. 1996, 17, 41-46. [CrossRef]

414. Nomura, M.; Ishitani, M.; Takabe, T.; Rai, A.K.; Takabe, T. Synechococcus sp. PCC7942 transformed with Escherichia coli bet genes produces glycine betaine from choline and acquires resistance to salt stress. Plant Physiol. 1995, 107, 703-708. [CrossRef]

415. Kaku, N.; Hibino, T.; Tanaka, Y.; Ishikawa, H.; Araki, E.; Takabe, T.; Takabe, T. Effects of overexpression of Escherichia coli katE and bet genes on the tolerance for salt stress in a freshwater cyanobacterium Synechococcus sp. PCC 7942. Plant Sci. 2000, 159, 281-288. [CrossRef]

416. De Deng, M.; Coleman, J.R. Ethanol synthesis by genetic engineering in cyanobacteria. Appl. Environ. Microbiol. 1999, 65, 523-528. [CrossRef]

417. Fukuda, H.; Sakai, M.; Nagahama, K.; Fujii, T.; Matsuoka, M.; Inoue, Y.; Ogawa, T. Heterologous expression of the gene for the ethylene-forming enzyme from Pseudomonas syringae in the cyanobacterium Synechococcus. Biotechnol. Lett. 1994, 16, 1-6. [CrossRef]

418. Sakai, M.; Ogawa, T.; Matsuoka, M.; Fukuda, H. Photosynthetic conversion of carbon dioxide to ethylene by the recombinant cyanobacterium, Synechococcus sp. PCC 7942, which harbors a gene for the ethylene-forming enzyme of Pseudomonas syringae. J. Ferment. Bioeng. 1997, 4, 434-443. [CrossRef]

419. Jindou, S.; Ito, Y.; Mito, N.; Uematsu, K.; Hosoda, A.; Tamura, H. Engineered platform for bioethylene production by a cyanobacterium expressing a chimeric complex of plant enzymes. ACS Synth. Biol. 2014, 3, 487-496. [CrossRef] [PubMed]

420. Iwaki, T.; Haranoh, K.; Inoue, N.; Kojima, K.; Satoh, R.; Nishino, T.; Wada, S.; Ihara, H.; Tsuyama, S.; Kobayashi, H.; et al. Expression of foreign type I ribulose-1,5-bisphosphate carboxylase/ oxygenase (EC 4.1.1.39) stimulates photosynthesis in cyanobacterium Synechococcus PCC7942 cells. Photosynth. Res. 2006, 88, 287-297. [CrossRef] [PubMed]

421. Chen, Y.; Taton, A.; Go, M.; London, R.E.; Pieper, L.M.; Golden, S.S.; Golden, J.W. Self-replicating shuttle vectors based on pANS, a small endogenous plasmid of the unicellular cyanobacterium Synechococcus elongatus PCC 7942. Microbiology (UK) 2016, 162, 2029-2041. [CrossRef]

422. Scholz, P.; Haring, V.; Wittmann-Liebold, B.; Ashman, K.; Bagdasarian, M.; Scherzinger, E. Complete nucleotide sequence and gene organization of the broad-host-range plasmid RSF1010. Gene 1989, 75, 271-288. [CrossRef]

423. Bagdasarian, M.; Lurz, R.; Rückert, B.; Franklin, F.C.H.; Bagdasarian, M.M.; Frey, J.; Timmis, K.N. Specific-purpose plasmid cloning vectors II. Broad host range, high copy number, RSF 1010-derived vectors, and a host-vector system for gene cloning in Pseudomonas. Gene 1981, 16, 237-247. [CrossRef]

424. Kues, U.; Stahl, U. Replication of plasmids in gram-negative bacteria. Microbiol. Rev. 1989, 53, 491-516. [CrossRef] [PubMed] 
425. Meyer, R. Replication and conjugative mobilization of broad host-range IncQ plasmids. Plasmid 2009, 62, 57-70. [CrossRef] [PubMed]

426. Kreps, S.; Ferino, F.; Mosrin, C.; Gerits, J.; Mergeay, M.; Thuriaux, P. Conjugative transfer and autonomous replication of a promiscuous IncQ plasmid in the cyanobacterium Synechocystis PCC 6803. MGG Mol. Gen. Genet. 1990, 221, 129-133. [CrossRef]

427. Sode, K.; Tatara, M.; Takeyama, H.; Burgess, J.G.; Matsunaga, T. Conjugative gene transfer in marine cyanobacteria: Synechococcus sp., Synechocystis sp. and Pseudanabaena sp. Appl. Microbiol. Biotechnol. 1992, 37, 369-373. [CrossRef] [PubMed]

428. Mermet-Bouvier, P.; Cassier-Chauvat, C.; Marraccini, P.; Chauvat, F. Transfer and replication of RSF1010-derived plasmids in several cyanobacteria of the genera Synechocystis and Synechococcus. Curr. Microbiol. 1993, 27, 323-327. [CrossRef]

429. Mühlenhoff, U.; Chauvat, F. Gene transfer and manipulation in the thermophilic cyanobacterium Synechococcus elongatus. Mol. Gen. Genet. 1996, 252, 93-100. [CrossRef] [PubMed]

430. Brahamsha, B. A genetic manipulation system for oceanic cyanobacteria of the genus Synechococcus. Appl. Environ. Microbiol. 1996, 62, 1745-1751. [CrossRef]

431. Guo, H.; Xu, X. Broad host range plasmid-based gene transfer system in the cyanobacterium Gloeobacter violaceus which lacks thylakoids. Prog. Nat. Sci. 2004, 14, 31-35. [CrossRef]

432. Araki, M.; Shimada, Y.; Mimuro, M.; Tsuchiya, T. Establishment of the reporter system for a thylakoid-lacking cyanobacterium, Gloeobacter violaceus PCC 7421. FEBS Open Bio 2013, 3, 11-15. [CrossRef]

433. Tolonen, A.C.; Liszt, G.B.; Hess, W.R. Genetic manipulation of Prochlorococcus strain MIT9313: Green fluorescent protein expression from an RSF1010 plasmid and Tn5 transposition. Appl. Environ. Microbiol. 2006, 72, 7607-7613. [CrossRef]

434. Huang, H.H.; Camsund, D.; Lindblad, P.; Heidorn, T. Design and characterization of molecular tools for a synthetic biology approach towards developing cyanobacterial biotechnology. Nucleic Acids Res. 2010, 38, 2577-2593. [CrossRef] [PubMed]

435. Bishé, B.; Taton, A.; Golden, J.W. Modification of RSF1010-Based Broad-Host-Range Plasmids for Improved Conjugation and Cyanobacterial Bioprospecting. iScience 2019, 20, 216-228. [CrossRef] [PubMed]

436. Taton, A.; Lis, E.; Adin, D.M.; Dong, G.; Cookson, S.; Kay, S.A.; Golden, S.S.; Golden, J.W. Gene transfer in Leptolyngbya sp. strain BL0902, a cyanobacterium suitable for production of biomass and bioproducts. PLoS ONE 2012, 7, e30901. [CrossRef]

437. Mermet-Bouvier, P.; Chauvat, F. A conditional expression vector for the cyanobacteria Synechocystis sp. strains PCC6803 and PCC6714 or Synechococcus sp. strains PCC7942 and PCC6301. Curr. Microbiol. 1994, 28, 145-148. [CrossRef] [PubMed]

438. Mazouni, K.; Bulteau, S.; Cassier-Chauvat, C.; Chauvat, F. Promoter element spacing controls basal expression and light inducibility of the cyanobacterial secA gene. Mol. Microbiol. 1998, 30, 1113-1122. [CrossRef]

439. Dutheil, J.; Saenkham, P.; Sakr, S.; Leplat, C.; Ortega-Ramos, M.; Bottin, H.; Cournac, L.; Cassier-Chauvat, C.; Chauvat, F. The AbrB2 autorepressor, expressed from an atypical promoter, represses the hydrogenase operon to regulate hydrogen production in Synechocystis strain PCC6803. J. Bacteriol. 2012, 194, 5423-5433. [CrossRef]

440. Mazouni, K.; Domain, F.; Cassier-Chauvat, C.; Chauvat, F. Molecular analysis of the key cytokinetic components of cyanobacteria: FtsZ, ZipN and MinCDE. Mol. Microbiol. 2004, 52, 1145-1158. [CrossRef]

441. Marbouty, M.; Saguez, C.; Cassier-Chauvat, C.; Chauvat, F. Characterization of the FtsZ-interacting septal proteins SepF and Ftn6 in the spherical-celled cyanobacterium Synechocystis strain PCC 6803. J. Bacteriol. 2009, 191, 6178-6185. [CrossRef]

442. Marbouty, M.; Saguez, C.; Cassier-Chauvat, C.; Chauvat, F. ZipN, an FtsA-like orchestrator of divisome assembly in the model cyanobacterium Synechocystis PCC6803. Mol. Microbiol. 2009, 74, 409-420. [CrossRef]

443. Damrow, R.; Maldener, I.; Zilliges, Y. The multiple functions of common microbial carbon polymers, glycogen and PHB, during stress responses in the non-diazotrophic cyanobacterium Synechocystis sp. PCC 6803. Front. Microbiol. 2016, 7. [CrossRef]

444. Ng, W.O.; Zentella, R.; Wang, Y.; Taylor, J.S.A.; Pakrasi, H.B. phrA, the major photoreactivating factor in the cyanobacterium Synechocystis sp. strain PCC 6803 codes for a cyclobutane-pyrimidine-dimer- specific DNA photolyase. Arch. Microbiol. 2000, 173, 412-416. [CrossRef]

445. De Porcellinis, A.J.; Nørgaard, H.; Brey, L.M.F.; Erstad, S.M.; Jones, P.R.; Heazlewood, J.L.; Sakuragi, Y. Overexpression of bifunctional fructose-1,6-bisphosphatase/sedoheptulose-1,7-bisphosphatase leads to enhanced photosynthesis and global reprogramming of carbon metabolism in Synechococcus sp. PCC 7002. Metab. Eng. 2018, 47, 170-183. [CrossRef] [PubMed]

446. Dienst, D.; Wichmann, J.; Mantovani, O.; Rodrigues, J.S.; Lindberg, P. High density cultivation for efficient sesquiterpenoid biosynthesis in Synechocystis sp. PCC 6803. Sci. Rep. 2020, 10, 5932. [CrossRef]

447. Liang, F.; Englund, E.; Lindberg, P.; Lindblad, P. Engineered cyanobacteria with enhanced growth show increased ethanol production and higher biofuel to biomass ratio. Metab. Eng. 2018, 46, 51-59. [CrossRef]

448. Guerrero, F.; Carbonell, V.; Cossu, M.; Correddu, D.; Jones, P.R. Ethylene Synthesis and Regulated Expression of Recombinant Protein in Synechocystis sp. PCC 6803. PLoS ONE 2012, 7, e50470. [CrossRef] [PubMed]

449. Kuchmina, E.; Klähn, S.; Jakob, A.; Bigott, W.; Enke, H.; Dühring, U.; Wilde, A. Ethylene production in Synechocystis sp. PCC 6803 promotes phototactic movement. Microbiology (UK) 2017, 16, 1937-1947. [CrossRef] [PubMed]

450. Thiel, K.; Mulaku, E.; Dandapani, H.; Nagy, C.; Aro, E.M.; Kallio, P. Translation efficiency of heterologous proteins is significantly affected by the genetic context of RBS sequences in engineered cyanobacterium Synechocystis sp. PCC 6803. Microb. Cell Fact. 2018, 17, 34. [CrossRef] [PubMed]

451. Van der Woude, A.D.; Perez Gallego, R.; Vreugdenhil, A.; Puthan Veetil, V.; Chroumpi, T.; Hellingwerf, K.J. Genetic engineering of Synechocystis PCC6803 for the photoautotrophic production of the sweetener erythritol. Microb. Cell Fact. 2016, 15. [CrossRef] 
452. Ortega-Ramos, M.; Jittawuttipoka, T.; Saenkham, P.; Czarnecka-Kwasiborski, A.; Bottin, H.; Cassier-Chauvat, C.; Chauvat, F. Engineering Synechocystis PCC6803 for hydrogen production: Influence on the tolerance to oxidative and sugar stresses. PLoS ONE 2014, 9, e89372. [CrossRef]

453. Veaudor, T.; Cassier-Chauvat, C.; Chauvat, F. Overproduction of the cyanobacterial hydrogenase and selection of a mutant thriving on urea, as a possible step towards the future production of hydrogen coupled with water treatment. PLoS ONE 2018, 13, e0198836. [CrossRef]

454. Miao, R.; Liu, X.; Englund, E.; Lindberg, P.; Lindblad, P. Isobutanol production in Synechocystis PCC 6803 using heterologous and endogenous alcohol dehydrogenases. Metab. Eng. Commun. 2017, 5, 45-53. [CrossRef] [PubMed]

455. Miao, R.; Xie, H.; Ho, F.M.; Lindblad, P. Protein engineering of $\alpha$-ketoisovalerate decarboxylase for improved isobutanol production in Synechocystis PCC 6803. Metab. Eng. 2018, 47, 42-48. [CrossRef] [PubMed]

456. Loeschcke, A.; Dienst, D.; Wewer, V.; Hage-Hülsmann, J.; Dietsch, M.; Kranz-Finger, S.; Hüren, V.; Metzger, S.; Urlacher, V.B.; Gigolashvili, T.; et al. The photosynthetic bacteria Rhodobacter capsulatus and Synechocystis sp. PCC 6803 as new hosts for cyclic plant triterpene biosynthesis. PLoS ONE 2017, 12, e189816. [CrossRef] [PubMed]

457. Carroll, A.L.; Case, A.E.; Zhang, A.; Atsumi, S. Metabolic engineering tools in model cyanobacteria. Metab. Eng. 2018, 50, 47-56. [CrossRef] [PubMed]

458. Yao, L.; Shabestary, K.; Björk, S.M.; Asplund-Samuelsson, J.; Joensson, H.N.; Jahn, M.; Hudson, E.P. Pooled CRISPRi screening of the cyanobacterium Synechocystis sp PCC 6803 for enhanced industrial phenotypes. Nat. Commun. 2020, 11. [CrossRef] [PubMed]

459. Hihara, Y.; Kamei, A.; Kanehisa, M.; Kaplan, A.; Ikeuchi, M. DNA microarray analysis of cyanobacterial gene expression during acclimation to high light. Plant Cell 2001, 13, 793-806. [CrossRef] [PubMed]

460. Hihara, Y.; Sonoike, K.; Kanehisa, M.; Ikeuchi, M. DNA microarray analysis of redox-responsive genes in the genome of the cyanobacterium Synechocystis sp. strain PCC 6803. J. Bacteriol. 2003, 185, 1719-1725. [CrossRef]

461. Kanesaki, Y.; Suzuki, I.; Allakhverdiev, S.I.; Mikami, K.; Murata, N. Salt stress and hyperosmotic stress regulate the expression of different sets of genes in Synechocystis sp. PCC 6803. Biochem. Biophys. Res. Commun. 2002, 290, 339-348. [CrossRef] [PubMed]

462. Marin, K.; Suzuki, I.; Yamaguchi, K.; Ribbeck, K.; Yamamoto, H.; Kanesaki, Y.; Hagemann, M.; Murata, N. Identification of histidine kinases that act as sensors in the perception of salt stress in Synechocystis sp. PCC 6803. Proc. Natl. Acad. Sci. USA 2003, 100, 9061-9066. [CrossRef]

463. Marin, K.; Kanesaki, Y.; Los, D.A.; Murata, N.; Suzuki, I.; Hagemann, M. Gene expression profiling reflects physiological processes in salt acclimation of Synechocystis sp. strain PCC 6803. Plant Physiol. 2004, 13, 3290-3300. [CrossRef]

464. Shoumskaya, M.A.; Paithoonrangsarid, K.; Kanesaki, Y.; Los, D.A.; Zinchenko, V.V.; Tanticharoen, M.; Suzuki, I.; Murata, N Identical Hik-Rre systems are involved in perception and transduction of salt signals and hyperosmotic signals but regulate the expression of individual genes to different extents in Synechocystis. J. Biol. Chem. 2005, 280, 21531-21538. [CrossRef]

465. Mikami, K.; Kanesaki, Y.; Suzuki, I.; Murata, N. The histidine kinase Hik33 perceives osmotic stress and cold stress in Synechocystis sp. PCC 6803. Mol. Microbiol. 2002, 46, 905-915. [CrossRef]

466. Ohta, H.; Shibata, Y.; Haseyama, Y.; Yoshino, Y.; Suzuki, T.; Kagasawa, T.; Kamei, A.; Ikeuchi, M.; Enami, I. Identification of genes expressed in response to acid stress in Synechocystis sp. PCC 6803 using DNA microarrays. Photosynth. Res. 2005, 84, 225-230. [CrossRef] [PubMed]

467. Uchiyama, J.; Asakura, R.; Kimura, M.; Moriyama, A.; Tahara, H.; Kobayashi, Y.; Kubo, Y.; Yoshihara, T.; Ohta, H. Slr0967 and Sllo939 induced by the SphR response regulator in Synechocystis sp. PCC 6803 are essential for growth under acid stress conditions. Biochim. Biophys. Acta Bioenerg. 2012, 1817, 1270-1276. [CrossRef]

468. Suzuki, I.; Kanesaki, Y.; Hayashi, H.; Hall, J.J.; Simon, W.J.; Slabas, A.R.; Murata, N. The histidine kinase Hik34 is involved in thermotolerance by regulating the expression of heat shock genes in Synechocystis. Plant Physiol. 2005, 138, 1409-1421. [CrossRef] [PubMed]

469. Suzuki, I.; Simon, W.J.; Slabas, A.R. The heat shock response of Synechocystis sp. PCC 6803 analysed by transcriptomics and proteomics. J. Exp. Bot. 2006, 57, 1573-1578. [CrossRef] [PubMed]

470. Rowland, J.G.; Pang, X.; Suzuki, I.; Murata, N.; Simon, W.J.; Slabas, A.R. Identification of components associated with thermal acclimation of photosystem II in Synechocystis sp. PCC6803. PLoS ONE 2010, 5, e10511. [CrossRef] [PubMed]

471. Paithoonrangsarid, K.; Shoumskaya, M.A.; Kanesaki, Y.; Satoh, S.; Tabata, S.; Los, D.A.; Zinchenko, V.V.; Hayashi, H.; Tanticharoen, M.; Suzuki, I.; et al. Five histidine kinases perceive osmotic stress and regulate distinct sets of genes in Synechocystis. J. Biol. Chem. 2004, 279, 53078-53086. [CrossRef] [PubMed]

472. Shapiguzov, A.; Lyukevich, A.A.; Allakhverdiev, S.I.; Sergeyenko, T.V.; Suzuki, I.; Murata, N.; Los, D.A. Osmotic shrinkage of cells of Synechocystis sp. PCC 6803 by water efflux via aquaporins regulates osmostress-inducible gene expression. Microbiology 2005, 151, 447-455. [CrossRef]

473. Kobayashi, M.; Ishizuka, T.; Katayama, M.; Kanehisa, M.; Bhattacharyya-Pakrasi, M.; Pakrasi, H.B.; Ikeuchi, M. Response to oxidative stress involves a novel peroxiredoxin gene in the unicellular cyanobacterium Synechocystis sp. PCC 6803. Plant Cell Physiol. 2004, 45, 290-299. [CrossRef] [PubMed]

474. Houot, L.; Floutier, M.; Marteyn, B.; Michaut, M.; Picciocchi, A.; Legrain, P.; Aude, J.C.; Cassier-Chauvat, C.; Chauvat, F. Cadmium triggers an integrated reprogramming of the metabolism of Synechocystis PCC6803, under the control of the Slr1738 regulator. BMC Genom. 2007, 8. [CrossRef] [PubMed] 
475. Kanesaki, Y.; Yamamoto, H.; Paithoonrangsarid, K.; Shoumskaya, M.; Suzuki, I.; Hayashi, H.; Murata, N. Histidine kinases play important roles in the perception and signal transduction of hydrogen peroxide in the cyanobacterium, Synechocystis sp. PCC 6803. Plant J. 2007, 49, 313-324. [CrossRef] [PubMed]

476. Zhang, Z.; Pendse, N.D.; Phillips, K.N.; Cotner, J.B.; Khodursky, A. Gene expression patterns of sulfur starvation in Synechocystis sp. PCC 6803. BMC Genom. 2008, 9. [CrossRef]

477. Leplat, C.; Champeimont, R.; Saenkham, P.; Cassier-Chauvat, C.; Jean-Christophe, A.; Chauvat, F. Genome-wide transcriptome analysis of hydrogen production in the cyanobacterium Synechocystis: Towards the identification of new players. Int. J. Hydrog. Energy 2013, 38, 1866-1872. [CrossRef]

478. Mitschke, J.; Georg, J.; Scholz, I.; Sharma, C.M.; Dienst, D.; Bantscheff, J.; Voß, B.; Steglich, C.; Wilde, A.; Vogel, J.; et al. An experimentally anchored map of transcriptional start sites in the model cyanobacterium Synechocystis sp. PCC6803. Proc. Natl. Acad. Sci. USA 2011, 108, 2124-2129. [CrossRef]

479. Muro-Pastor, A.M.; Hess, W.R. Regulatory RNA at the crossroads of carbon and nitrogen metabolism in photosynthetic cyanobacteria. Biochim. Biophys. Acta Gene Regul. Mech. 2020, 1863, 194477. [CrossRef]

480. Baumgartner, D.; Kopf, M.; Klähn, S.; Steglich, C.; Hess, W.R. Small proteins in cyanobacteria provide a paradigm for the functional analysis of the bacterial micro-proteome. BMC Microbiol. 2016, 16. [CrossRef]

481. Huang, S.; Chen, L.; Te, R.; Qiao, J.; Wang, J.; Zhang, W. Complementary iTRAQ proteomics and RNA-seq transcriptomics reveal multiple levels of regulation in response to nitrogen starvation in Synechocystis sp. PCC 6803. Mol. Biosyst. 2013, 9, 2565-2574 [CrossRef]

482. Pei, G.; Sun, T.; Chen, S.; Chen, L.; Zhang, W. Systematic and functional identification of small non-coding RNAs associated with exogenous biofuel stress in cyanobacterium Synechocystis sp. PCC 6803. Biotechnol. Biofuels 2017, 10. [CrossRef]

483. Hernández-Prieto, M.A.; Semeniuk, T.A.; Futschik, M.E. Toward a systems-level understanding of gene regulatory, protein interaction, and metabolic networks in cyanobacteria. Front. Genet. 2014, 5. [CrossRef]

484. Nakao, M.; Okamoto, S.; Kohara, M.; Fujishiro, T.; Fujisawa, T.; Sato, S.; Tabata, S.; Kaneko, T.; Nakamura, Y. CyanoBase: The cyanobacteria genome database update 2010. Nucleic Acids Res. 2009, 38, D379-D381. [CrossRef]

485. Zhang, Y.; Fonslow, B.R.; Shan, B.; Baek, M.C.; Yates, J.R. Protein analysis by shotgun/bottom-up proteomics. Chem. Rev. 2013, 113, 2343-2394. [CrossRef] [PubMed]

486. Gao, L.; Wang, J.; Ge, H.; Fang, L.; Zhang, Y.; Huang, X.; Wang, Y. Toward the complete proteome of Synechocystis sp. PCC 6803. Photosynth. Res. 2015, 126, 203-219. [CrossRef] [PubMed]

487. Gao, L.; Shen, C.; Liao, L.; Huang, X.; Liu, K.; Wang, W.; Guo, L.; Jin, W.; Huang, F.; Xu, W.; et al. Functional proteomic discovery of Slr0110 as a central regulator of carbohydrate metabolism in Synechocystis species PCC6803. Mol. Cell. Proteom. 2014, 13, 204-219. [CrossRef]

488. Song, Z.; Chen, L.; Wang, J.; Lu, Y.; Jiang, W.; Zhang, W. A transcriptional regulator Sll0794 regulates tolerance to biofuel ethanol in photosynthetic Synechocystis sp. PCC 6803. Mol. Cell. Proteom. 2014, 13, 3519-3532. [CrossRef] [PubMed]

489. Chen, W.; Fang, L.; Huang, X.; Ge, H.; Wang, J.; Wang, X.; Zhang, Y.; Sui, N.; Xu, W.; Wang, Y. Systematic identification of light-regulated cold-responsive proteome in a model cyanobacterium. J. Proteom. 2018, 179, 100-109. [CrossRef]

490. Angeleri, M.; Muth-Pawlak, D.; Wilde, A.; Aro, E.M.; Battchikova, N. Global proteome response of Synechocystis 6803 to extreme copper environments applied to control the activity of the inducible petJ promoter. J. Appl. Microbiol. 2019, 126, 826-841. [CrossRef]

491. Battchikova, N.; Vainonen, J.P.; Vorontsova, N.; Kerãnen, M.; Carmel, D.; Aro, E.M. Dynamic changes in the proteome of Synechocystis 6803 in response to $\mathrm{CO}_{2}$ limitation revealed by quantitative proteomics. J. Proteome Res. 2010, 9, 5896-5912. [CrossRef]

492. Miranda, H.; Cheregi, O.; Netotea, S.; Hvidsten, T.R.; Moritz, T.; Funk, C. Co-expression analysis, proteomic and metabolomic study on the impact of a Deg/HtrA protease triple mutant in Synechocystis sp. PCC 6803 exposed to temperature and high light stress. J. Proteom. 2013, 78, 294-311. [CrossRef]

493. Slabas, A.R.; Suzuki, I.; Murata, N.; Simon, W.J.; Hall, J.J. Proteomic analysis of the heat shock response in Synechocystis PCC6803 and a thermally tolerant knockout strain lacking the histidine kinase 34 gene. Proteomics 2006, 6, 845-864. [CrossRef] [PubMed]

494. Rowland, J.G.; Simon, W.J.; Prakash, J.S.S.; Slabas, A.R. Proteomics reveals a role for the RNA helicase crhR in the modulation of multiple metabolic pathways during cold acclimation of Synechocystis sp. PCC6803. J. Proteome Res. 2011, 10, 3674-3689. [CrossRef] [PubMed]

495. Zhang, L.F.; Yang, H.M.; Cui, S.X.; Hu, J.; Wang, J.; Kuang, T.Y.; Norling, B.; Huang, F. Proteomic analysis of plasma membranes of cyanobacterium Synechocystis sp. strain PCC 6803 in response to high pH stress. J. Proteome Res. 2009, 8, 2892-2902. [CrossRef] [PubMed]

496. Kurian, D.; Phadwal, K.; Mäenpää, P. Proteomic characterization of acid stress response in Synechocystis sp. PCC 6803. Proteomics 2006, 6, 3614-3624. [CrossRef]

497. Ren, Q.; Shi, M.; Chen, L.; Wang, J.; Zhang, W. Integrated proteomic and metabolomic characterization of a novel two-component response regulator Slr1909 involved in acid tolerance in Synechocystis sp. PCC 6803. J. Proteom. 2014, 109, 76-89. [CrossRef] [PubMed] 
498. Wegener, K.M.; Singh, A.K.; Jacobs, J.M.; Elvitigala, T.; Welsh, E.A.; Keren, N.; Gritsenko, M.A.; Ghosh, B.K.; Camp, D.G.; Smith, R.D.; et al. Global proteomics reveal an atypical strategy for carbon/nitrogen assimilation by a cyanobacterium under diverse environmental perturbations. Mol. Cell. Proteom. 2010, 12, 2678-2689. [CrossRef]

499. Fuszard, M.A.; Ow, S.Y.; Gan, C.S.; Noirel, J.; Ternan, N.G.; McMullan, G.; Biggs, C.A.; Reardon, K.F.; Wright, P.C. The quantitative proteomic response of Synechocystis sp. PCC6803 to phosphate acclimation. Aquat. Biosyst. 2013, 9. [CrossRef]

500. Chen, L.; Zhu, Y.; Song, Z.; Wang, J.; Zhang, W. An orphan response regulator Sll0649 involved in cadmium tolerance and metal homeostasis in photosynthetic Synechocystis sp. PCC 6803. J. Proteom. 2014, 103, 87-102. [CrossRef]

501. Mehta, A.; López-Maury, L.; Florencio, F.J. Proteomic pattern alterations of the cyanobacterium Synechocystis sp. PCC 6803 in response to cadmium, nickel and cobalt. J. Proteom. 2014, 102, 98-112. [CrossRef]

502. Fulda, S.; Huang, F.; Nilsson, F.; Hagemann, M.; Norling, B. Proteomics of Synechocystis sp. strain PCC 6803: Identification of periplasmic proteins in cells grown at low and high salt concentrations. Eur. J. Biochem. 2000, 267, 5900-5907. [CrossRef]

503. Fulda, S.; Mikkat, S.; Huang, F.; Huckauf, J.; Marin, K.; Norling, B.; Hagemann, M. Proteome analysis of salt stress response in the cyanobacterium Synechocystis sp. strain PCC 6803. Proteomics 2006, 6, 2733-2745. [CrossRef]

504. Huang, F.; Fulda, S.; Hagemann, M.; Norling, B. Proteomic screening of salt-stress-induced changes in plasma membranes of Synechocystis sp. strain PCC 6803. Proteomics 2006, 6, 910-920. [CrossRef]

505. Pandhal, J.; Ow, S.Y.; Wright, P.C.; Biggs, C.A. Comparative proteomics study of salt tolerance between a nonsequenced extremely halotolerant cyanobacterium and its mildly halotolerant relative using in vivo metabolic labeling and in vitro isobaric labeling. $J$. Proteome Res. 2009, 8, 818-828. [CrossRef]

506. Li, T.; Yang, H.M.; Cui, S.X.; Suzuki, I.; Zhang, L.F.; Li, L.; Bo, T.T.; Wang, J.; Murata, N.; Huang, F. Proteomic study of the impact of Hik33 mutation in Synechocystis sp. PCC 6803 under normal and salt stress conditions. J. Proteome Res. 2012, 11, 502-514. [CrossRef]

507. Qiao, J.; Huang, S.; Te, R.; Wang, J.; Chen, L.; Zhang, W. Integrated proteomic and transcriptomic analysis reveals novel genes and regulatory mechanisms involved in salt stress responses in Synechocystis sp. PCC 6803. Appl. Microbiol. Biotechnol. 2013, 97, 8253-8264. [CrossRef] [PubMed]

508. Gao, Y.; Xiong, W.; Li, X.B.; Gao, C.F.; Zhang, Y.L.; Li, H.; Wu, Q.Y. Identification of the proteomic changes in Synechocystis sp. PCC 6803 following prolonged UV-B irradiation. J. Exp. Bot. 2009, 60, 1141-1154. [CrossRef]

509. Liu, J.; Chen, L.; Wang, J.; Qiao, J.; Zhang, W. Proteomic analysis reveals resistance mechanism against biofuel hexane in Synechocystis sp. PCC 6803. Biotechnol. Biofuels 2012, 5. [CrossRef] [PubMed]

510. Qiao, J.; Wang, J.; Chen, L.; Tian, X.; Huang, S.; Ren, X.; Zhang, W. Quantitative iTRAQ LC-MS/MS proteomics reveals metabolic responses to biofuel ethanol in cyanobacterial Synechocystis sp. PCC 6803. J. Proteome Res. 2012, 11, 5286-5300. [CrossRef] [PubMed]

511. Tian, X.; Chen, L.; Wang, J.; Qiao, J.; Zhang, W. Quantitative proteomics reveals dynamic responses of Synechocystis sp. PCC 6803 to next-generation biofuel butanol. J. Proteom. 2013, 78, 326-345. [CrossRef] [PubMed]

512. Chen, L.; Wu, L.; Wang, J.; Zhang, W. Butanol tolerance regulated by a two-component response regulator Slr1037 in photosynthetic Synechocystis sp. PCC 6803. Biotechnol. Biofuels 2014, 7. [CrossRef] [PubMed]

513. Wang, Y.; Chen, L.; Zhang, W. Proteomic and metabolomic analyses reveal metabolic responses to 3-hydroxypropionic acid synthesized internally in cyanobacterium Synechocystis sp. PCC 6803. Biotechnol. Biofuels 2016, 9. [CrossRef] [PubMed]

514. Ma, Y.; Yang, M.; Lin, X.; Liu, X.; Huang, H.; Ge, F. Malonylome Analysis Reveals the Involvement of Lysine Malonylation in Metabolism and Photosynthesis in Cyanobacteria. J. Proteome Res. 2017, 15, 2030-2043. [CrossRef]

515. Lin, X.; Yang, M.; Liu, X.; Cheng, Z.; Ge, F. Characterization of Lysine Monomethylome and Methyltransferase in Model Cyanobacterium Synechocystis sp. PCC 6803. Genom. Proteom. Bioinform. 2020, 18, 289-304. [CrossRef] [PubMed]

516. Mikkat, S.; Fulda, S.; Hagemann, M. A 2D gel electrophoresis-based snapshot of the phosphoproteome in the cyanobacterium Synechocystis sp. strain PCC 6803. Microbiology (UK) 2014, 160, 296-306. [CrossRef] [PubMed]

517. Spät, P.; Macek, B.; Forchhammer, K. Phosphoproteome of the cyanobacterium Synechocystis sp. PCC 6803 and its dynamics during nitrogen starvation. Front. Microbiol. 2015, 6. [CrossRef] [PubMed]

518. Toyoshima, M.; Tokumaru, Y.; Matsuda, F.; Shimizu, H. Assessment of protein content and phosphorylation level in Synechocystis sp. PCC 6803 under various growth conditions using quantitative phosphoproteomic analysis. Molecules 2020, 20, 3582. [CrossRef]

519. Krall, L.; Huege, J.; Catchpole, G.; Steinhauser, D.; Willmitzer, L. Assessment of sampling strategies for gas chromatography-mass spectrometry (GC-MS) based metabolomics of cyanobacteria. J. Chromatogr. B Anal. Technol. Biomed. Life Sci. 2009, 877, 2952-2960. [CrossRef]

520. Narainsamy, K.; Cassier-Chauvat, C.; Junot, C.; Chauvat, F. High performance analysis of the cyanobacterial metabolism via liquid chromatography coupled to a LTQ-Orbitrap mass spectrometer: Evidence that glucose reprograms the whole carbon metabolism and triggers oxidative stress. Metabolomics 2013, 9, 21-32. [CrossRef]

521. Achyuthan, K.E.; Harper, J.C.; Manginell, R.P.; Moorman, M.W. Volatile metabolites emission by in vivo microalgae-An overlooked opportunity? Metabolites 2017, 7, 39. [CrossRef]

522. Majchrzak, T.; Wojnowski, W.; Rutkowska, M.; Wasik, A. Real-Time Volatilomics: A Novel Approach for Analyzing Biological Samples. Trends Plant Sci. 2020, 25, 302-312. [CrossRef] 
523. Yoshikawa, K.; Hirasawa, T.; Ogawa, K.; Hidaka, Y.; Nakajima, T.; Furusawa, C.; Shimizu, H. Integrated transcriptomic and metabolomic analysis of the central metabolism of Synechocystis sp. PCC 6803 under different trophic conditions. Biotechnol. J. 2013, 8, 571-580. [CrossRef]

524. Nakajima, T.; Kajihata, S.; Yoshikawa, K.; Matsuda, F.; Furusawa, C.; Hirasawa, T.; Shimizu, H. Integrated metabolic flux and omics analysis of Synechocystis sp. PCC 6803 under mixotrophic and photoheterotrophic conditions. Plant Cell Physiol. 2014, 55, 1605-1612. [CrossRef] [PubMed]

525. Cheregi, O.; Miranda, H.; Gröbner, G.; Funk, C. Inactivation of the Deg protease family in the cyanobacterium Synechocystis sp. PCC 6803 has impact on the outer cell layers. J. Photochem. Photobiol. B Biol. 2015, 152, 383-394. [CrossRef] [PubMed]

526. Klähn, S.; Orf, I.; Schwarz, D.; Matthiessen, J.K.F.; Kopka, J.; Hess, W.R.; Hagemann, M. Integrated transcriptomic and metabolomic characterization of the low-carbon response using an ndhR mutant of Synechocystis sp. PCC 6803. Plant Physiol. 2015, 169, 1540-1556. [CrossRef]

527. Jablonsky, J.; Papacek, S.; Hagemann, M. Different strategies of metabolic regulation in cyanobacteria: From transcriptional to biochemical control. Sci. Rep. 2016, 6. [CrossRef] [PubMed]

528. Saha, R.; Liu, D.; Hoynes-O'Connor, A.; Liberton, M.; Yu, J.; Bhattacharyya-Pakrasi, M.; Balassy, A.; Zhang, F.; Moon, T.S.; Maranas, C.D.; et al. Diurnal regulation of cellular processes in the cyanobacterium Synechocystis sp. strain PCC 6803: Insights from transcriptomic, fluxomic, and physiological analyses. MBio 2016, 7, e00464-16. [CrossRef] [PubMed]

529. Tibiletti, T.; Hernández-Prieto, M.A.; Matthijs, H.C.P.; Niyogi, K.K.; Funk, C. Deletion of the gene family of small chlorophyllbinding proteins (ScpABCDE) offsets C/N homeostasis in Synechocystis PCC 6803. Biochim. Biophys. Acta Bioenerg. 2016, 1857, 396-407. [CrossRef] [PubMed]

530. Hasunuma, T.; Matsuda, M.; Kondo, A. Improved sugar-free succinate production by Synechocystis sp. PCC 6803 following identification of the limiting steps in glycogen catabolism. Metab. Eng. Commun. 2016, 3, 130-141. [CrossRef]

531. Zhu, H.; Ren, X.; Wang, J.; Song, Z.; Shi, M.; Qiao, J.; Tian, X.; Liu, J.; Chen, L.; Zhang, W. Integrated OMICS guided engineering of biofuel butanol-tolerance in photosynthetic Synechocystis sp. PCC 6803. Biotechnol. Biofuels 2013, 6. [CrossRef] [PubMed]

532. Liu, Z.X.; Li, H.C.; Wei, Y.P.; Chu, W.Y.; Chong, Y.L.; Long, X.H.; Liu, Z.P.; Qin, S.; Shao, H.B. Signal transduction pathways in Synechocystis sp. PCC 6803 and biotechnological implications under abiotic stress. Crit. Rev. Biotechnol. 2015, 35, 269-280. [CrossRef] [PubMed]

533. Gärtner, K.; Klähn, S.; Watanabe, S.; Mikkat, S.; Scholz, I.; Hess, W.R.; Hagemann, M. Cytosine N4-methylation via M.Ssp6803II is involved in the regulation of transcription, fine-tuning of DNA replication and DNA repair in the cyanobacterium Synechocystis sp. PCC 6803. Front. Microbiol. 2019, 10. [CrossRef]

534. Xu, W.; Wang, Y. Post-translational Modifications of Serine/Threonine and Histidine Kinases and Their Roles in Signal Transductions in Synechocystis Sp. PCC 6803. Appl. Biochem. Biotechnol. 2020. [CrossRef] [PubMed]

535. Broddrick, J.T.; Rubin, B.E.; Welkie, D.G.; Du, N.; Mih, N.; Diamond, S.; Lee, J.J.; Golden, S.S.; Palsson, B.O. Unique attributes of cyanobacterial metabolism revealed by improved genome-scale metabolic modeling and essential gene analysis. Proc. Natl. Acad. Sci. USA 2016, 113, E8344-E8353. [CrossRef]

536. Broddrick, J.T.; Welkie, D.G.; Jallet, D.; Golden, S.S.; Peers, G.; Palsson, B.O. Predicting the metabolic capabilities of Synechococcus elongatus PCC 7942 adapted to different light regimes. Metab. Eng. 2019, 52, 42-56. [CrossRef] [PubMed] 